\title{
Cancer cell ploidy and proliferation in colorectal carcinoma
}

Citation for published version (APA):

Schutte, B. (1987). Cancer cell ploidy and proliferation in colorectal carcinoma. [Doctoral Thesis, Maastricht University]. Rijksuniversiteit Limburg. https://doi.org/10.26481/dis.19870522bs

Document status and date:

Published: 01/01/1987

DOI:

10.26481/dis.19870522bs

Document Version:

Publisher's PDF, also known as Version of record

\section{Please check the document version of this publication:}

- A submitted manuscript is the version of the article upon submission and before peer-review. There can be important differences between the submitted version and the official published version of record.

People interested in the research are advised to contact the author for the final version of the publication, or visit the DOI to the publisher's website.

- The final author version and the galley proof are versions of the publication after peer review.

- The final published version features the final layout of the paper including the volume, issue and page numbers.

Link to publication

\footnotetext{
General rights rights.

- You may freely distribute the URL identifying the publication in the public portal. please follow below link for the End User Agreement:

www.umlib.nl/taverne-license

Take down policy

If you believe that this document breaches copyright please contact us at:

repository@maastrichtuniversity.nl

providing details and we will investigate your claim.
}

Copyright and moral rights for the publications made accessible in the public portal are retained by the authors and/or other copyright owners and it is a condition of accessing publications that users recognise and abide by the legal requirements associated with these

- Users may download and print one copy of any publication from the public portal for the purpose of private study or research.

- You may not further distribute the material or use it for any profit-making activity or commercial gain

If the publication is distributed under the terms of Article $25 \mathrm{fa}$ of the Dutch Copyright Act, indicated by the "Taverne" license above, 
CANCER CELL PLOIDY AND PROLIFERATION IN COLORECTAL CARCINOMA 
Graphic design by Karin Danëls

printed by T.O. Oliset 


\section{CANCER CELL PLOIDY AND PROLIFERATION IN COLORECTAL. CARCINOMA}

Proefschrift ter verkrijging van de graad van doctor in de geneeskunde aan de Rijksuniversiteit Limburg te Maastricht, op gezag van de Rector Magnificus, Prof.Dr. F.I.M. Bonke, volgens het besluit van het College van Dekanen, in het openbaar te verdedigen op vrijdag 22 mei 1987 des namiddags te 16.00 uur door Berend Schutte geboren te Diepenveen. 
$\begin{array}{ll}\text { Promotores: } & \text { Prof.Dr. F.T. Bosman } \\ & \text { Prof.Dr. G.H. Blijham } \\ \text { Referenten: } & \text { Prof.Dr. B. Barlogie } \\ & \text { Prof.Dr. A. Böcking } \\ & \text { Prof.Dr. J.P.M. Geraedts }\end{array}$

This study was financially supported by EURO-DIAGNOSTICS, Apeldoorn. 
In memory of my mother 


\section{Introduction}

Introduction $\quad 2$

1.1 DNA abnormalities 3

1.2 Quantitative DNA measurements 3

1.2.1 DNA flow cytometry 3

1.2.2 Cellular DNA content 5

1.2.3 Cell cycle distribution 5

1.3 Clinical and biological significance of tumor ploidy $\quad 7$

1.4 Aim of the present study 8

References 10

2 Flow cytometric determination of DNA ploidy level in nuclei isolated from paraffin-embedded tissue

Introduction $\quad 16$

2. Materials and Methods 16

2.2 Results 18

2.3 Discussion 2】

References 23

3 Ploidy level and proliferative activity in colorectal carcinoma: correlation with clinicopathological and immunohistochemical parameters

Introduction

3. Materials and Methods 26

3.2 Results 28

3.3 Discussion 30

References $\quad 33$

4 Comparison of phenotypic and genotypic reatures in primary large bowel carcinomas and lymphnode metastases

Introduction 36

4.1 Materials and Methods 36

$\begin{array}{lll}4.2 & \text { Results } & 38\end{array}$

4.3 Discussion 41

References $\quad 43$ 
5 The prognostic significance of DNA content and proliferative activity in large bowell carcinoma

Introduction $\quad 46$

5.1 Materials and Methods 46

5.2 Results 48

5.3 Discussion 51

References $\quad 53$

${ }^{6}$ Limitations of DNA flow cytometric analysis: The rationale for dynamic cytokinetic studies

Determination of S-phase fractions 56

6.1 Methods for the measurements of cell

kinetic parameters 56

6.2 Clinical significance 57

6.3 Outline of the study 57

References $\quad 59$

$\overline{7}^{-}$Studies with anti-bromodeoxyuridine antibodies. I. An improved method for the immunocytochemical detection of BrdU labeled nuclei using flow cytometry

$\begin{array}{lll} & \text { Introduction } & 62 \\ 7.1 & \text { Materials and Methods } & 62 \\ 7.2 & \text { Results } & 65 \\ 7.3 & \text { Discussion } & 68 \\ & \text { References } & 71\end{array}$

8 The effect of tissue fixation on anti-bromodeoxyuridine immunohistochemistry

Introduction

8.1 Materials and Methods 74

8.2 Results 75

8.3 Discussion 78

$\begin{array}{ll}\text { References } & 79\end{array}$ 
9 Studies with anti-bromodeoxyuridine antibodies. II. Simultaneous immunocytochemical detection of antigen expression and DNA synthesis by in vivo labeling of mouse intestinal mucosa Introduction $\quad 82$

9.1 Materials and Methods $\quad 82$

9.2 Results 85

9.3 Discussion $\quad 86$

References $\quad 90$

$10^{-1}$ Kinetic studies of colorectal cell lines grown in vitro and in vivo

Introduction $\quad 92$

10.1 Materials and Methods 93

10.2 Results 96

$\begin{array}{lll}10.3 & \text { Discussion } & 99\end{array}$

References 104

11 Discussion

$\begin{array}{ll}\text { Introduction } & 106\end{array}$

11.1 Aneuploidy 106

$\begin{array}{ll}\text { 11.1.1 Biological significance of aneuploidy } & 107\end{array}$

11.1.2 Clinical relevance of aneuploidy 108

$\begin{array}{lll}11.2 & \text { Cell kinetics } & 108\end{array}$

11.2.1 Immunocytochemical detection of BrdU 110

11.2.2 Biological significance of tumor cell kinetics 110

11.2.3 Clinical relevance of tumor cell kinetics 111

11.3 Concluding remarks 112

References 113

Summary 114

Summary (in Dutch) 117

$\begin{array}{ll}\text { List of publications } & 120\end{array}$

$\begin{array}{ll}\text { List of abbreviations } & 122\end{array}$

$\begin{array}{ll}\text { Acknowledgements } & 123\end{array}$

$\begin{array}{ll}\text { Curriculum vitae } & 125\end{array}$ 
INTRODUCTION 


\section{Introduction}

In the last 30 years dramatic improvements in the prognosis of patients suffering from colorectal cancer have not been achieved. At the time of diagnosis in approximately $50 \%$ of the patients presenting with this disease, tumor cells have spread beyond the stage of surgical and radiotherapeutical control. Moreover, those disseminated cells have shown considerable resistance to methods of systemic treatment, such as cytostatic drugs.

Recently, evidence has been presented for some beneficial effect of postsurgical treatment with infusion of the liver with 5fluorouracil (1) or combined radio- and chemotherapy in colonic and rectal cancer respectively (2). Also, in patients with disseminated colorectal cancer, responses have been obtained using lymphokines both ex vivo and in vivo (3). The advances of fered by these treatments, though promising, are modest at best and paid for by considerable morbidity and, in some cases, treatment-related mortality. These modalities should therefore at this time mainly be regarded as starting points for further research. It has now become recognized that malignant diseases which are usually indicated under one diagnosis, e.g. colorectal cancer, are in fact heterogeneous in several aspects. For example, in colorectal cancer differences are observed in genotype (4), phenotype (5) and tumorgenicity in athymic mice (6). This heterogeneity can be nicely illustrated by referring to the situation in acute leukemia; acute lymphoblastic leukemias appear to be heterogeneous as far as the immunotypes of the cells are concerned and for acute myeloblastic leukemia a subclassification. (7, 8) can be made on the basis of specific cytogenetic abnormalities. It is of great importance that such subclassifications confer prognostic information and have been shown to be therapeutically relevant $(9,10)$.

By a similar reasoning, clinical research in colorectal cancer as indicated above would be greatly facilitated if biologically relevant markers could be identified. For this, the study of abnormalities in DNA content have been shown a promising approach. Some aspects of DNA measurements in tumor cells will be briefly discussed. 


\subsection{DNA abnormalities}

Karyotypic abnormalities have $l$ long been recognized in human cancers. Specific chromosomal rearrangements with or without concurrent gain or loss of cellular DNA may result in altered gene expression and if gene products related to regulation of cell division and differentiation are synthesized in abnormal amounts, neoplasia may be the result. Recently, a set of genes, the so-called oncogenes, has been recognized as playing an essential role in cell cycle control and differentiation (11-21). In haematological malignancies specific chromosomal abnormalities have been recognized. For instance chronic myeloid leukemia is nearly always accompanied by a 9,22 translocation, as is Burkitt's lymphoma with a translocation between chromosomes 8 and 14. In these chromosomal abnormalities oncogenes appear to be translocated $(22,23)$. Several indications have been obtained that the study of tumor cell genotype, at the level of the chromosome or even of the DNA might yield diagnostically or prognostically useful information $(10,22,23)$. However, direct karyotyping of solid tumors is technically difficult and time consuming as is a detailed analysis of DNA and these methods therefore are as yet not suited for large scale use.

\section{$\mathbf{1 . 2}$ Quantitative DNA measurements}

A more feasible approach to determine genomic aberrations is the quantitative measurement of cellular DNA content either by microscope based systems or by flow cytometry (FCM). In this way, there is a loss of resolution, but the applicability and the statistical accuracy of the measurements are increased. For this approach interphase cells can be used which extends the applicability of these techniques to routine surgical specimens. Many recent comprehensive reviews adequately cover the practical and technical details of static cytometry $(24,25,26)$. In this chapter only the basic principles, potentials and limitations of flow cytometry will be discussed.

\subsubsection{DNA flow cytometry}

By flow cytometry the nuclear DNA content of a cell can be quantitatively measured at high speed, thereby increasing the statistical accuracy (27). In principle, a suspension of single cells or nuclei is stained with a fluorescent dye that binds stoichiometrically to the DNA, i.e. the amount of dye bound is 
proportional to the amount of DNA. The stained cells or nuclei are then forced through a narrow orifice into a jet stream, which is intercepted by a laserbeam, tuned to the appropriate wavelength to excite the dye (figure 1). The emitted light per cell is collected through a set of filters and is recorded as a measure of the DNA content of a cell. Samples can be analyzed at rates of 1000 cells per second.

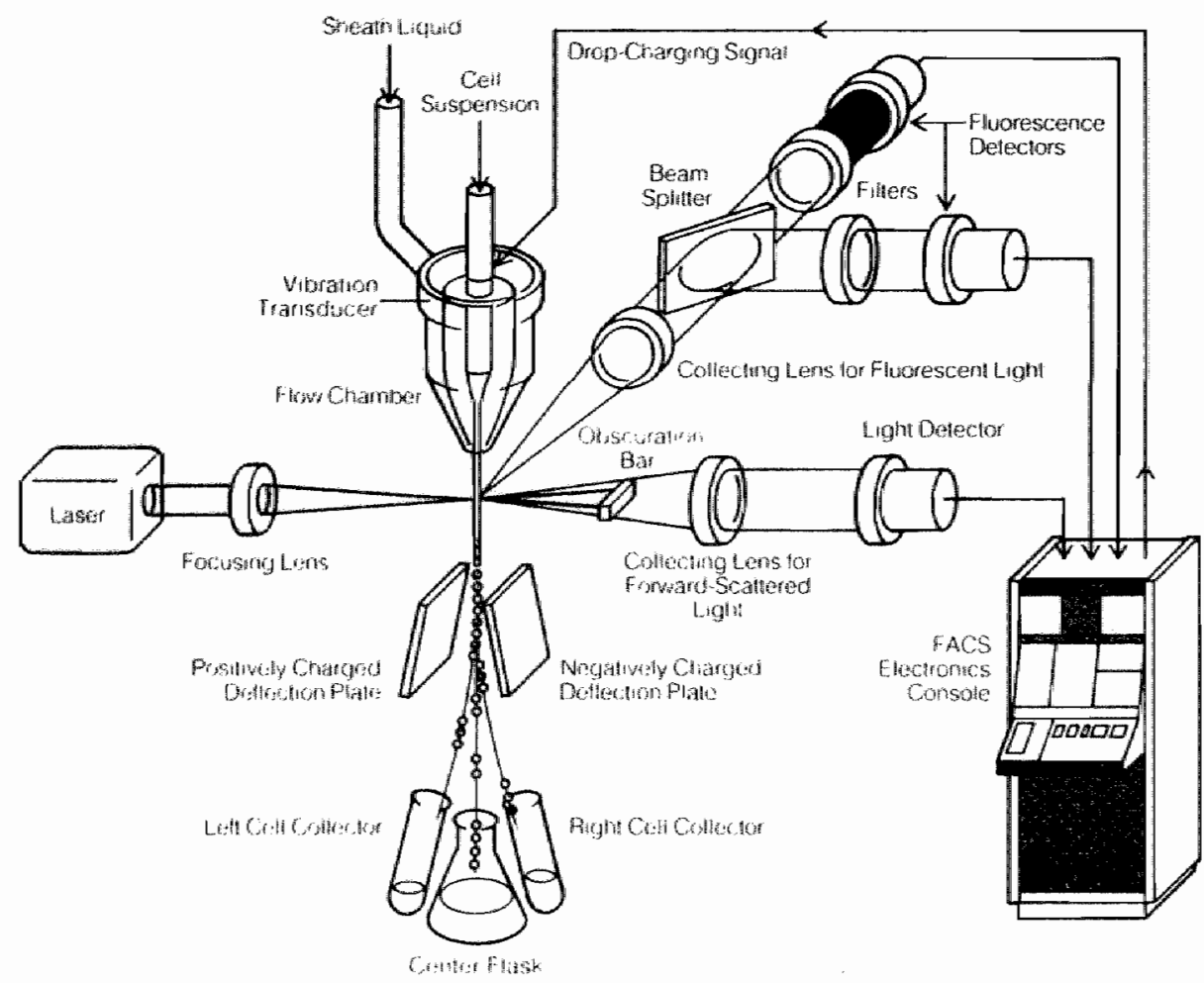

Figure 1 Basio principle of a llow cycometer. 


\section{2 .2 Cellular DNA content}

A typical histogram is shown in figure 2. Since the analysis is not an absolute measurement of cellular DNA content, reference cells are admixed with the sample to identify the position of cells with a normal diploid amount of DNA. Human leucocytes or chicken and trout red blood cells are often used as reference cells. Deviations in cellular DNA content (aneuploidy) are expressed as a DNA index, i.e. the ratio of sample DNA peak channel to reference DNA peak channel. A DNA index of 1.0 represents a normal diploid DNA content, while a DNA index of 1.5 represents a triploid DNA content. Differences as small as $5 \%$ of the total cellular DNA content can be identified, depending on the ratio of normal to abnormal cells and on the resolution of the DNA histogram. In contrast to karyotyping, FCM cannot detect balanced chromosomal translocations and/or small deletions or chromosomal gains and losses.

Ploidy levels have been determined in a variety of solid tumors (28) and showed a characteristic bimodal distribution with a relative predominance of tumors having a diploid or a near triploid-tetraploid mode (figure 3). The incidence of aneuploidy is high, ranging from 50 to $90 \%$. Some tumors contain subpopulations with different DNA indices, which are able to proliferate. These subpopulations are often referred to as stemlines.

\subsubsection{Cell cycle distribution}

Apart from measuring the relative DNA content of $G_{1}$ cells, quantitative cytology also gives information regarding the distribution of cells in the various phases of the cell cycle. In a proliferating cell population 4 distinct phases can be recognized: the DNA synthesis phase (S-phase), mitosis (M-phase), the gap between $M$ and $S\left(G_{1}\right.$-phase) and the gap between $S$ and $M\left(G_{2}-\right.$ phasel. Cells in the $\mathrm{G}_{1^{-}}, \mathrm{S}$ - and $\mathrm{G}_{2}+\mathrm{M}$-phases of the cell cycle can be discriminated on the basis of the differences in DNA content. Mathematical models have been developed to calculate the percentages of cells occupying the different phases of the cell cycle from a single DNA histogram $(29,30)$. In theory, the percentage of $\mathrm{S}$-phase cells should be indicative for the proliferative activity of a tumor. However, there are several reasons why an accurate measurement of S-phase cells cannot be made from a single DNA histogram. Firstly, there is a mathematical inaccuracy of resolving the DNA histogram into the various phases of the cell cycle due to overlapping populations of $\mathrm{G}_{1} / \mathrm{S}$ 


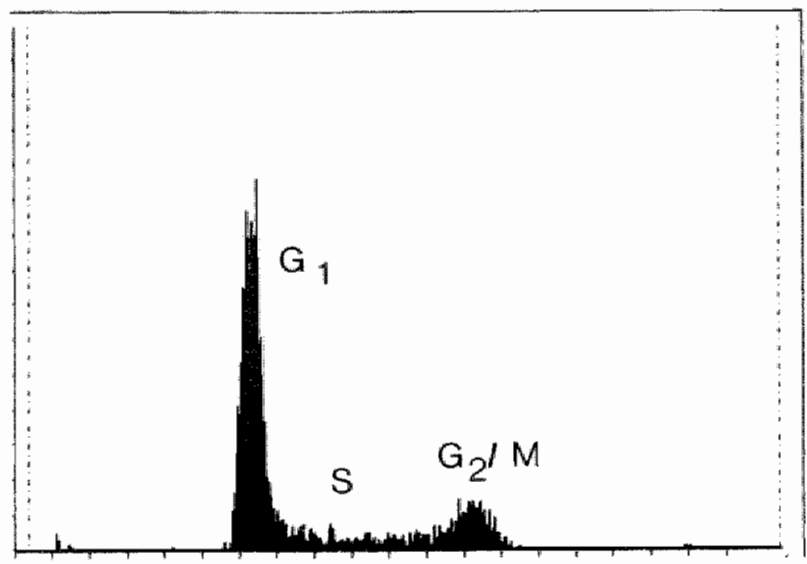

Figure 2 DWA histogram of exponentially growing cells in vitro. Abcis: relative DNA content. Ordingte:" cell number.

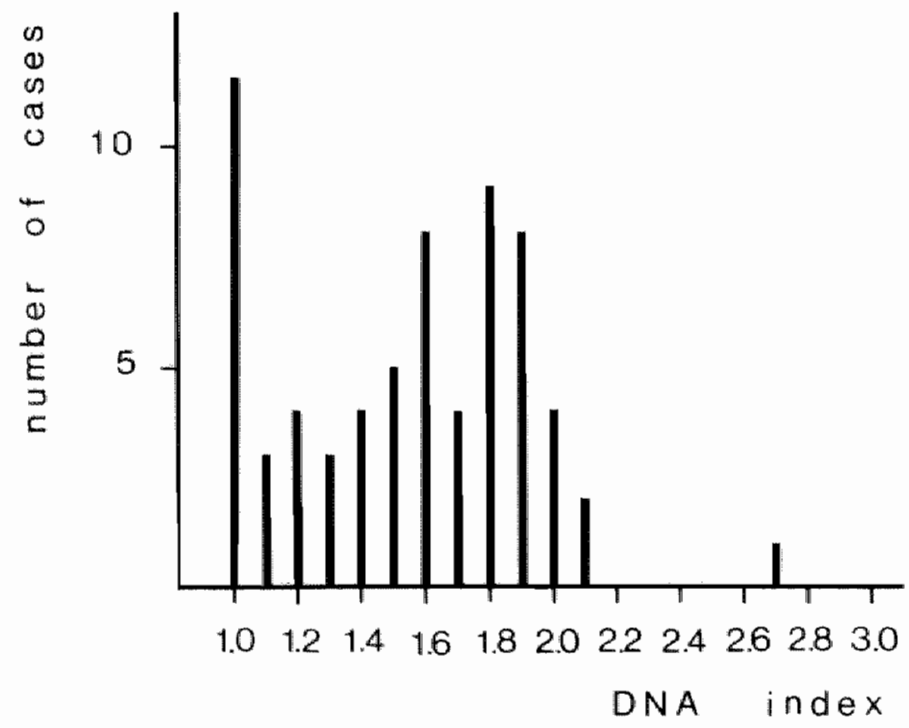

Figure 3 frequency distribution of DNA undices of 70 cases of colorecul cancer. 
and $S / G_{2} \mathrm{M}$ cells. Secondly, the presence of an unknown number of noncycling normal cells, such as fibroblasts or infiltrating cells, will lead to an underestimation of the proliferative activity of the tumor. In addition, the proliferative activity within a tumor might not be randomly distributed and therefore subject to sampling bias. Thirdly, no information is obtained about the numbers of noncycling tumor celıs, which are thought to have a $\mathrm{G}_{1}$ amount of DNA ( $\mathrm{G}_{0}$ cells), and cell cycle traverse rates.

\section{$\overline{1.3}$ Clinical and biological significance of tumor ploidy}

In recent years, evidence has been accumulated that in a number of tumor types certain patterns of ploidy abnormalities are reflected in the biological behaviour. In general diploid tumors were found to have a better prognosis and to be associated with a higher degree of differentiation as compared to aneuploid tumors of similar origin (table 1) $(28,31)$.

\begin{tabular}{|c|c|c|c|c|c|c|}
\hline \multirow{2}{*}{$\begin{array}{l}\text { Tumor } \\
\text { lype }\end{array}$} & \multirow{2}{*}{$\begin{array}{l}\text { survival } \\
\text { advantage } \\
\text { for diploid }\end{array}$} & \multicolumn{4}{|c|}{ ploidy correlates with } & \multirow[b]{2}{*}{ ref. } \\
\hline & & stage & $\begin{array}{l}\text { histological } \\
\text { subtype }\end{array}$ & $\begin{array}{l}\text { histological } \\
\text { grade? }\end{array}$ & others & \\
\hline Breast & + & - & + & + & \multirow{4}{*}{$\begin{array}{l}\text { ER receptor } \\
\text { borderline } \\
\text { malignancy } \\
\text { lymph node } \\
\text { spread }\end{array}$} & $38-46$ \\
\hline Ovary & + & + & - & \pm & & $47-53$ \\
\hline Cervix & + & - & $\ldots$ & - & & $54-56$ \\
\hline \multicolumn{2}{|c|}{ Endometriuma } & - & - & + & & $57-58$ \\
\hline Prostate: & + & - & - & + & \multirow[t]{4}{*}{$\begin{array}{l}\text { hormone } \\
\text { responsivenessis }\end{array}$} & $59-68$ \\
\hline Bhinder & ; & + & - & + & & $59,65-70$ \\
\hline Roonat & 4 & - & -- & s. & & $7 \|-73$ \\
\hline I.41178 & $i$ & 4 & - & $\sim$ & & $74-78$ \\
\hline Codins & * & - & - & - & \multirow[t]{4}{*}{$\begin{array}{l}\text { CEA } \\
\text { proxelesedion }\end{array}$} & $32-35,79$ \\
\hline Mulanteomat & - & - & - & - & & 80,81 \\
\hline Bratu & - & - & - & - & & $82-87$ \\
\hline Bum & 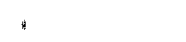 & + & $*$ & $*$ & & $88-89$ \\
\hline
\end{tabular}

from friedlander of al. (28). 
In colorectal cancer data relating DNA index to survival are emerging rapidly. Wolley et al. (32) were the first to describe a favourable prognosis for patients with diploid colorectal tumors. Only 6 of 20 patients with diploid tumors died of disease during a follow-up period of 3 to 5 years, in contrast to 12 of 13 patients with aneuploid tumors. Recently, Armitage et al. (33) and Kokal et al. (34) confirmed these findings in larger series of respectively 134 and 77 patients. Both studies demonstrated that in a stepwise logistic analysis the DNA index was an independent prognostic variable predicting recurrent disease. On the other hand, Melamed et al. (35) failed to show any prognostic advantage for diploid tumors during a follow-up period of 3 years of 33 patients.

Limited data are available regarding proliferative characteristics in relation to prognosis in colorectal cancer. Meyer et al. (36) analyzed 100 resected colorectal carcinomas by in vitro exposure to $\left[{ }^{3} \mathrm{H}\right]$-thymidine and autoradiography. No relation was found between the $\left[{ }^{3} \mathrm{H}\right]$-thymidine labeling index and stage, survival or relapse-free survival of the patients. In contrast, Trotter et al. (37) demonstrated that the $\left[{ }^{3} \mathrm{H}\right]$-thymidine labeling index for Dukes' stage A and B tumors was significantly higher than for Dukes' stages $C$ and D.

\subsection{Aim of the present study}

From this introduction it may be apparent that in colorectal cancer a search for new pretreatment prognostic parameters is of great importance. Based on current knowledge regarding karyotypic abnormalities in leukemias and lymphomas and on the rapidly emerging data on measurements of DNA content of solid tumors, we decided to investigate ploidy levels and S-phase fractions in a large series of colorectal carcinomas. Until recently, flow cytometry was restricted to the use of fresh tumor tissue; as a consequence, studies regarding the prognostic information of cellular DNA content were progressing slowly. Therefore, we investigated in chapter 2 the feasibility of using paraffin-embedded material for determining cellular DNA content. The incidence and stability in time of aneuploidy in relation with clinicopathological and immunohistochemical parameters will be discussed in chapters 3 and 4 respectively. Chapter 5 describes a retrospective analysis of the prognostic significance of DNA content in relation to stage of disease in 279 
colorectal cancer patients, the largest series described sofar. Chapter 6 summarizes the limitations and presents the rationale for a more dynamic approach of DNA flow cytometry, which allows cytokinetic studies through bromodeoxyuridine (BrdU) labeling. In the second part of this thesis, the BrdU based methods are described and the applications of this methodology to various aspects of cancer cell biology are described. In the final chapter general conclusions are drawn. 


\section{References}

1. Taylor I, Machin D, Muller $M$, Trotter $G$, Conke $T$, Wegt $C$. A randomized controlled trial of adjucht portal vein cytotoxic perfusion in colorectal cancer. Br J Surg 72: 359-363, 1985.

2. Gastrointestinal Tumor Study Group. Prolongation of the disease-free interval in surgically treated rectal carcinoma. W Engl / Med 312: 1405-1412, 1985.

3. Rosenberg SA, Lotze MT, Muli IM et al. Obserwations on the systemic administration of autolon. gous lymphokine-activated killer cells and recombinant interleukin-2 to patients with metastatic cencer. W Engl J Med 313: 1485-1492, 1985.

4. Petersen SE, Bichel P, Larenczen M. Flowcylometric demonstration of tumor cell subpopulations with different DNA content in human colorectal cancinoma. Eur J Cancer 15: 383-386, 1978.

5. Arends $\mathbb{l} W$, Bosman Fl, Higers J. Tissue antigens in large-bowel carcinorna. BBA 780: 1-19, 1985 .

6. Brituin $M G$, Levine AE, Chakrabarty $\mathrm{S}$, Yeoman $\mathrm{LC}$. Willsono $\mathrm{JKV}$, Lang B. Heterogeneity af human colon carcinoma. Cancer Metastasis Reviews 3: 177-191, 1984.

7. Foon KA, Schrof $R W$, Gale RP. Surface morkers on leukemia and lymphoma cells: recent advances. Brood 60: 1-14, 1982,

8. Kozinger $B$, Gebhard D, Denny T, McKenzie S, Clarkson BD, Miller DA, Evans RL. Analysis of T cell differentiation antigens in acute lymphatic levkenta using monoclonal antibodies. Blood: 60 : $752-757,1982$.

9. Greaves MF. Analysis of the clinical and biologiceal significance of lymphoid phenotypes in acure leukemia. Cancer Res 41: 4752-4763, 1981.

10. Fourth Intemational Workshop on Chromosomes in Leukemia. Cancer Genet Cycogemet March $1984)$.

11. Dutbecoo R. Oncogenes, cancer and development. In: Theories and Models in Cellular Transfornat tion. Academic Press Inc. (London, 1985, 1-9).

12. Kirsch tR, Bertness $V$, Siver J, Hollis G. Oncogene regulation during erythroid difrerentiation. In: L.werkemia: Recent Advances in Bjology and Treatment. Allan R. Liss Inc. 1985, $91 \cdots 98$,

13. Sacks L., Normal regulators, oncogenes and the rewersibility of malignancy. Cancer Surveys $3: 219$ $228,1984$.

14. Alatalok. Amplification of cellutar oncogenes in cancer cells. Medical Biology 62: 304-347, 1984.

15. Slamon DJ, Kernan JB, Verma JM, Cline MJ. Expression of cellular oncogenes in human malignancies. Science $224: 256-262,1984$.

16. Duprey SP, Boethinger D. Developmental regulation of c-myb in normal myeloid progeniton cels. Proc Natl Acad Sci 82: 6937-6941, 1985.

17. Tordli G, Selleri L, Donelli A, Ferrari S, Emilia G, Verturelli D, Moreth L, Torelli U. Activation of c-rnyb expression by phytohemoagglutinin stimulation in normal human $T$ lymphocyles. Molec Cell Biol 5: 2874-2877. 1985.

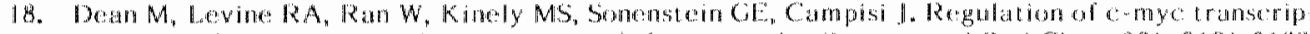

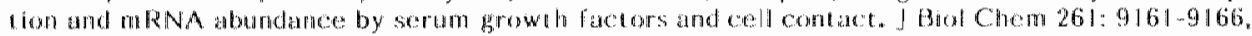
1986

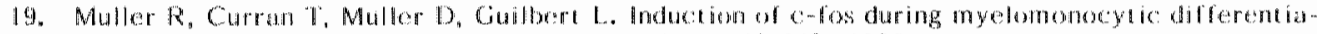
thon and macrophage probliferation. Nature $314: 546-548,1985$.

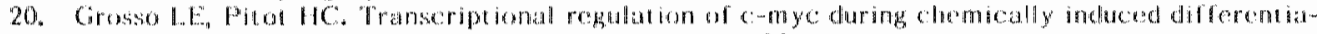
than of $1 / L-60$ cultures. Cuncet Kos $45: 847-850,1985$.

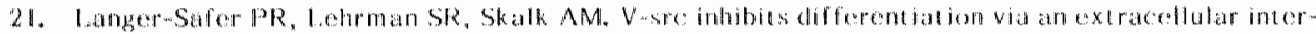
mediates(s). Moloe Cell Bind 5: 2847-2850, 1985.

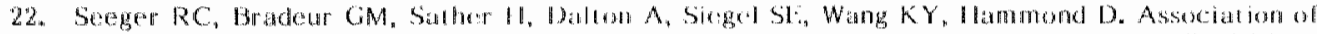

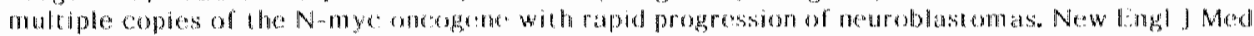
313: $1111-1116,1985$.

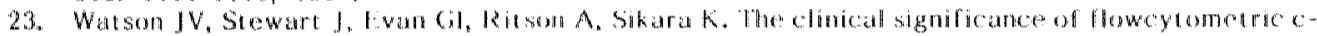

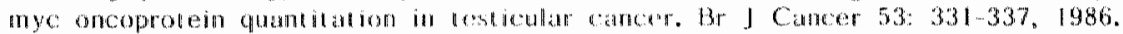

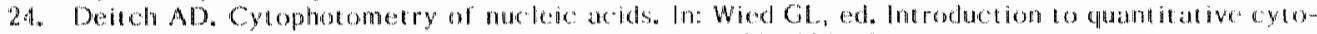
chembiry. Vol. I. New Yark: Academic Press, 1966 : 327-354.

25. Caspersson TO. Quantitative tumbur cylochomistry. In Chowes GHA ed. Memarial Lecture. Cant ceet Res 39: $2341-2355,1979$.

26. Fallentus A. DNA content and prognosis in breast cancer. Thesis. Karolinsta Institute and thospit at, Slockholm, 1986.

27. Steinkamp JA. Flowcytometry. Rev Sci lnstrum 55: 1375-1400, 1984.

28. Friedander ML, Hedley DW, Taylor IW. Clinical and biological significance of aneuphody in human tumours. J Clin Pathol 37: 961 974, 1984.

29. Basch U, Beck HP, Christensen 1], Hartaman NR, Frifd J. Dean PN, Gray JW, Jot! JH, Jatwaston DA, White RA, Nicolini $C$, Zeitz S, Watson NV. A comparison of mathematical methods for the 
analysis of DNA histograms obtaned by flowcytometry. Cell Tisstue kinet 15: 235-249, 1982.

30. Culpin D, Morris VB. Pattern of DNA synthesis and its effect on the classiftication of colls by flowcytometry. Cell Tissue Kinet 18 ; $1-12,1985$.

31. Barlogie $B_{\text {, }}$ aber MN, Schumann ec al. Perspectives in cancer research: flow cytometry in clinical cancer research. Cancer Research 43: $3982-3997,1983$.

32. Walley RC, Schreiber K, Koss LG, Karas M, Sherman A. DNA distribution in human colon caroi nomas and its relationship to clincal behaviour. J NCl $69: 15-22,1982$.

33. Armitage NC, Robins RA, Evans DF" Turner DR, Baldwin RC and Handcastle "ID. The influence of rumor cells DNA abnormalities on survival in colorectal cancer. Br J Surg 72: 828.830, 1985*

34. Kokal W, Scheibani $K$. Terz J, Harada R. Tumor DNA content in the prognosis of colorectal cancinoma. JAMA 255: 3123 , 1986.

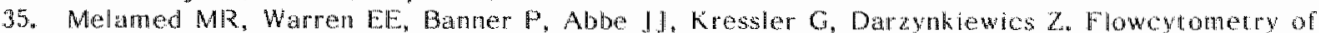
colorectal carcinoma with three year follow-up. Disease of the Colom and Rzchm 29: 184- 186 , 1986.

36. Meyer JS, Prioleau PG. S phase fractions of colorectal carcinomas related to pathologic and eliniw cal fextures. Cancer 48: 1221-1228, 1981.

37. Tronter GA Morgan GR, Cooper MI, Kirkham N, Whitehouse IMA, Taylor I. Cell kineric and in viro ctonogenicity of primary colorectat cancer. clincopathological relationships and the implications for chemotherapy. Giut 26: 267-273, 1985.

38. Auer GU, Caspersson TO, Walgren AS. DNA content and survival in manmary carcinoma. Anal and Quat Cytology 2: 161 165, 1980.

39. Olszewski W, Darzynkiewicz $Z$, Rosen PP, Schwart z MK, Melanted MR. F"lowcytometry of breast carcinoma. I. Relation of DNA ploidy level to histology and estrogen receptor. Cancer 48 . 980-984. 1981.

40. Taylor IW, Musgrove EA, Friedlander ML, Foo MS, Hedley DW. The intluence of age on the DNA ploidy levels of breast numours. Eur J Cancer Cin Oncol 19: 623 628. 1983.

41. Atkins NB. Modal deoxyribonucleic acid value and survival in carciloma of the breast. Br Mad 1 i: $271-272, \quad 1972$.

42. Kute TE. Muss HB, Anderson D et d. Relationship of steroid receptor, call kinetics and clinical status in patients with breast cancer. Cancer Res 41: $3524-3529.1981$.

43. Bichel P. Poulsen HS. Anderson J. Estrogen receptor content and ploidy of human mammary carcinoma. Cancer 50: $1771-1774,1982$.

44. Raber MN, Barlogie B, Latreille J, Bedrossian C, Fribche H, Blumenschein G. Ploidy, proliferative activity and estrogen receptor content in human breast cancer. Crtometry 3: 36-41, 1982.

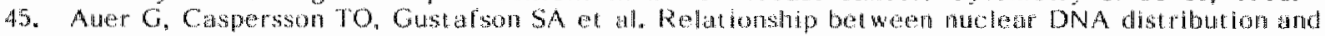
estrogen recoptors in human mammary curcimolnas. Anal and Quant Cytology 20: 438-441, 1980.

46. Hedley DW, Ragg CA. Taylor TW. Influence of cellular DNA conent on discase free surviwal in stage II brease cancer. Proc Am Soc Clin Oncol 3\% 120.1984.

47. Arkins NB. Modä DNA walue and chromosome number in ovarian neoplasia A clinical und histopathologic assessmerut. Cancer 27: 1064-1073, 1970.

48. Atkins NB, Kay R. Prognostic significance of modal DNA value and other factors in malgnant tumours based on 165 cases. Br J Cancer 40: 210-221, 1979.

49. Friedander ML. Taylor IW", Russel P. Musgrove EA, Hedley DW, Taltersill MHN. Plody a a prognostic factor in ovarian cancer. Int f Gynecol Pathol 2: 55-63, 1983.

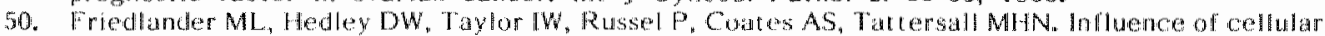
DNA content on survival in advanced ovarian carcer. Cancer Res 44: 397-400, 1984.

51. Friediander ML, Russel P, Taylor IW. Hedley DW, Tatiersall MHN. Flowcytometric analysis of Cellutar DNa content as an adjunct to the diagnosis of owarian tumours of borderline malighancy. Palthology : 6: $301-306,1984$.

52. Bader $\mathrm{S}$. Taylor HC. Engle ET. Deoxyribonucleic acid (DNA) content of human ovarian tumours in relation ro histological grading. Lab lnvest $9: 443-459,1960$.

53. Weiss R, Richart R, Okagaki T. DNA content of mucinous tumours of the ovary. Am I Obstet Gynecol 103: $409-424,1969$.

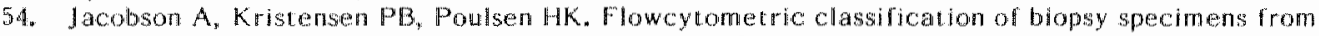
cervical inrapithelial neoplasia. Cytometry 4: 166-170, 1983.

55. Jacobson A. Ploidy level and short time prognosis of early cervix cancer. Radiother Oncol $1: 271$ 275,1984 .

56. Fi YS, Reagan JW, Fu AS, Janiga KE. Adenocarcinona and mixed carcinoma of the uterine cervix. 11. Prognostic walue of DNA analysis. Cancer 49: 2571-2577, 1982.

57. Feichter GE, wofken H, Heep J et al. DNA flowcytometric measurements on the normal, atro- 
phic, fyperplastic and neoplastic human endonetrium. Virch Airch (Pathol Anat) 398: 5365, 1982.

58. Atkins NB. Prognostic significance of ploidy level in fuman tumours. 1. Carcinoma of the uterus. I Narl Cancer Inse 56: 909-910, 1976.

59. Tavares $A S_{\text {, }}$ Costa J, De Carwalho $A$, Reis $M$. Tumour ploidy and prognosis in carcinomas of the bladder and prostate. Br f Cancer 20: $438-441,1966$.

60. Zetterberg A, Eposti PL. Progrostic significance of nuclear DNA levels in prostatic carcinoma. Scand J Urol Nephrol 55 (suppt): 53-59, 1980.

61. Sprenger E, Volk L, Michatis WE. The significance of nuclear DNA measurements in the diagnosis of prostatic carcinomas. Beitr Pathol 153: 370-378, 1974.

62. Bichel P, Frederiksen $P$, Kf Jaert $T$, Thommesen $P$, Vindelov LL. Flow microfluorometry and transrectal fine needle biopsy in the classification of human prostatic carcinoma. Cancer $40: 1206$ $1211,1977$.

63. Ronstran L, Tribukait B, Eposti PL. DNA pattern and cytological findings in fine needle aspirates of untreated prostatic tumours. A flowcytofluorometric study. Prostate 2: 79-88, 1981.

64. Tribukait B, Romstran L, Eposti PL. Quantitatiwe and qualitative aspects of flow DNA measurements related to the cytologic grade in prostatic carcinoma. Anal Quant Cytol 5: 107-111, 1983.

65. Tribukait $B$, Gustafson $H$, Eposti PL. The significance of ploidy and proliferation in the clinical and biological evaluation of bladder tumors. A study of 100 untreated cases. Br I Urol 54: 130 135,1982 .

66. Aufrermann W, Urguardt $M$, Rubben $H$, Wohtmann D, Bocking A. DNA grading of urothelial car-cinoma of the bladder. Anticancer Res 6: 27-32, 1986.

67. Fossa SD, Kaahihus 0, Scott-Knudsen 0 . The chinical and histopathological significance of Feulgen DNA walues in transitional cell carcinoma of the human, wrinary bladder. Eur J Cancer 13: 1155$1162,1977$.

68. Gustatson H, Tribukait B, Epost PL. The prognostic value of DNA analysis in primary carcinoma in situ of the urinary bladder. Scand J Urol Nephrol 6: 141-146, 1982.

69. Gustafson H, Tribukait B, Eposti PL. DNA pattern, histological grade and multiplicity related to recurrence rate in superficial bladder tumours. Scand J Urol Nephrol a: 135-139, 1982.

70. Gustafson H, Tribukait B, Eposti PL. DNA profile and tumour progression in patients with superficial bladder tumours. Scand J Urol Nephrol 10: 13-18, 1982.

71. Baisch H, Otto U, Kanig K, Kloppell G, Kollerman M, Linden WA. DNA content of human kidney carcinoma cells in relation to histological grading. Br I Cancer 45: 878-886, 1982.

72. Schwabe HW, Adolphs HD, Vogel J. Flow cytometric studies in renal carcinoma. Urol Res 11: 121.125 .1989

73. Bennington JL, Mayall BM. DNA cytometry on four micrometer sections of pararfin embedided human renal adenocarcinomas and adenomas. Cytometry 4: 31-39, 1983.

74. Olszewski W, Darzynklewicz Z, Claps ML, Melamed MR. Flow cytometry of lung carcinoma. A comparison of DNA stem line and cell cycle distribution with histology. Anal Quant Cytol 25: 90$94,1982$.

75. Adams L.R, Dahlgren SE. Cytophotometric measurements of the DNA content of lung tumours. Acta Pathol Microbiol Scand A 72: 561-574, 1968.

76, Johnson TS, Valdivieso M, Barlogie B, Jefferies D, Willamson K, Keating M. Flow cytometric ploldy and proliferative activity in human small cell lung

Carcinomas: Potential diagnostic and prognostic Features. Proc Am Assoc Cancer Res 488: 124, 1983.

77. Blanda: T, Lindgren A. Fluorescence cytophometric measurements of nuclear DNA in adenocarcinoma of the lung. Relation of probiferative activity and DNA ploidy to prognosis. Anal Quant Cytol 3: $225-232,1982$.

78. Blandal T, Bengtsson A. Nuclear DNA measurements in squamous cell carcinoma of the lung. $A_{4}$ guide for progmostic evaluation. Anticancer Res 1: 77-86, 1981.

79. Rognum TO, Thorud E, Elgjo K, Brandtzaeg P, Orjasaeter $H$, Nygaard K. Large bowel carcinomas with different ploidy related to secretory component, IgA and CEA in epithelium and plasma. $\mathrm{Br} J$ Cancer 45: 921-934, 1982.

80. Hansson J. Tribukait $B$, Levensohn R, Ringborg U. Flow cytofluorometric DNA analysis of metastases of human malignant melanomas. Anal Quant Cytol 25: 99-104, 1982.

81. Sandergaard K, Larsen $\mathbb{K}$, Moller U, Christensen IJ. Jensen KH. DNA ploidy characteristics of human malignant melanoma analysed by flow cytometry and compared with histology and clinical course. Virch Arch (Cell Pathol) 42: 43-52, 1983.

82. Frederickson $P$, Bichel $P$. Sequential flow analysis of the single cell DNA content in recurrent human brain tumors. In: Laerum OD, Ludmo T, Thorud E, eds. Flowcytometry IV. Oslo: Univer- 
sitetsforlager $398-402,1980$.

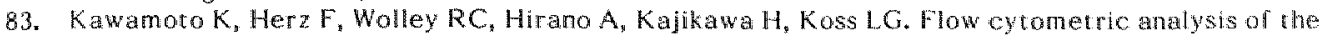
DNA distribution in human brain tumours. Acta Neuropathol Berl) 46: 39-44, 1979.

84. Lehmann J, Krug H. Flow through fluorocytophotometry of different brain tumours, Acta Neuropathol (Berl) $49: 123 \cdots 132,1980$.

85. De Reuck J, Sieben G, Coster W, Roels H, van der Eeken H. Cytophotometric DNA determination in thuman oligodendroglial tumors. Histopathology 4: 225-232, 1980.

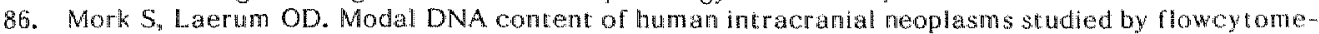
1ry. I Neurosurg 53: $198-204$, 1980.

87. Kajkawa H. Kawamoto K, Herz F, Wolley RC. Hirano A, Koss LG. Flow through cytomery of meningiomas and cultured meningioma cells. Acta Neuropathol (Berl) 44: 183-187, 1978.

88. Kreicbergs A, Bromstrom LA, Ceurien G, Eirhorn S. Cellular DNA content in humam osteosarcoma. Aspects on diagrosis and prognosis Cancer 50: 2476-2481, 1982.

89. Kreicbergs A. Boguisi L, Borssen B, Larsson S. Prognostic factors in chondrosarcoma. A compararive srudy of cellular DNA content and clinicopathological leatures. Cancer 50: 577-583, 1982. 
FLOW CYTOMETRIC DETERMINATION OF DNA PLOIDY LEVEL IN NUCLEI ISOLATED FROM PARAFFIN-EMBEDDED TISSUE 


\section{Introduction}

In recent years studies of haematological malignancies have revealed prognostic implications for various specific karyotypic abnormalities. In solid tumor research, karyotyping is much more difficult to perform mainly because of methodological problems such as obtaining metaphase cells of sufficient number and quality to perform chromosome banding studies. With the introduction of flow cytometry it has become possible to study karyotypic abnormalities as reflected in DNA content (aneuploidy) in both haematological and solid tumors without being limited to the availability of metaphase cells. So far, a correlation between aneuploidy and well-known prognostic markers has been described for various solid tumors $(1,7-10)$. Since DNA flow cytometry required until recently fresh unfixed material, the progress in studies relating aneuploidy to disease-free interval and overall survival has been slow. DNA measurements in specimens processed for histological examination has been described using microdensitometry of Feulgen-stained sections of paraffin-embedded tissue. This technique, however, is laborious and does not seem to have the resolving power of flow cytometry. Recently, Hedley et al. $(4,5)$ developed a method to process paraffin-embedded material for flow cytometric DNA determination. They were, however, unable to estimate ploidy levels owing to intersample variations in fluorescence intensities. In this chapter we describe a modification of this technique and an investigation of the methodological variations which give rise to inconsistent ratios of diploid $G_{1}$ peaks of sample to reference standard. Furthermore, we present an alternative method of standarization that involves the admixture of nuclei from normal paraffin-embedded tissue of the same surgical specimen and processed under similar conditions as the primary tumor.

\subsection{Materials and Methods}

\section{Tissue}

Fresh unfixed tumor tissue was collected and transferred in RPMI 1640 supplemented with $10 \%$ newborn calf serum (NCS), penicillin (100 units/ml), and streptomycin (100 units/ml). All samples were stained according to the method of Vindelov et al. (12). Part of the same tumor tissue and normal mucosa, taken from a remote part of the surgical specimen, were fixed in $10 \%$ neutral buffered formalin and embedded in paraffin by routine histotechnical procedure. Chicken red blood cells (CRBC) were 
frozen and stored according to the method of Vindelov et al. (11). CRBC samples were thawed and fixed with varying cime intervals in $10 \%$ neutral buffered formalin.

\section{Preparation of Single Cells from Paraffin-Embedded Tissue}

A thin slice of paraffin-embedded tissue was scraped off the block surface with a scalpel. The tissue was cleared of paraffin with two changes of xylene for 1 hour at room temperature and rehydrated in a sequence of ethanol/xylene, $100 \%, 96 \%, 70 \%$ and $50 \%$ ethanol for 0.5 hour at room temperature. Samples were incubated in $0.25 \%$ trypsin (DIFCO) in citrate buffer $(3 \mathrm{mM}$ trisodiumcitrate, $0.1 \% \mathrm{v} / \mathrm{v}$ Nonidet $\mathrm{P} 40,1.5 \mathrm{mM}$ sperminetetrachloride, $0.5 \mathrm{mM}$ Tris, $\mathrm{pH} 7.6)$ overnight at $37^{\circ} \mathrm{C}$. After vortexing and filtration over a nylon mesh $(50 \mathrm{\mu m})$ approximately $2-3 \times 10^{6}$ cells were stained according to the method of Vindelov et al. (12).

\section{Propidium lodide (PI) Saturation}

In order to study the PI saturation kinetics, formalin-fixed CRBC (24 h, room temperature) were processed for paraffinembedding. Single cells were prepared as described above and stained with various PI concentrations (final concentration: 100 , $50,25,10,5$ and $2.5 \mu \mathrm{g} / \mathrm{ml})$.

\section{Measurement of PI Binding in Formalin-Fixed Cells}

CRBC were fixed for various time intervals in $10 \%$ neutral buffered formalin and stained for DNA content.

\section{Flow Cytometry}

Celluiar DNA content was measured on a FACS IV cell sorter (Becton and Dickinson, Sunnyvale, CA) equipped with a $2 \mathrm{~W}$ argon ion laser (Spectra Physics, model 164-01) operating at 488 nm. Histograms of $10^{4}$ cells were recorded and the DNA index (DI) was calculated as the ratio of aneuploid to diploid $\mathrm{G}_{1 / 0}$ peak channel. Histograms with coefficients of variation (CV) less than $8 \%$ were considered of good quality. In case of overlap of diploid and hyperdiploid histograms the percentage of S-phase cells was not calculated. 


\section{Introduction}

In recent years studies of haematological malignancies have revealed prognostic implications for various specific karyotypic abnormalities. In solid tumor research, karyotyping is much more difficult to perform mainly because of methodological problems such as obtaining metaphase cells of sufficient number and quality to perform chromosome banding studies. With the introduction of flow cytometry it has become possible to study karyotypic abnormalities as reflected in DNA content (aneuploidy) in both haematological and solid tumors without being limited to the availability of metaphase cells. So far, a correlation between aneuploidy and well-known prognostic markers has been described for various solid tumors $(1,7-10)$. Since DNA flow cytometry required until recently fresh unfixed material, the progress in studies relating aneuploidy to disease-free interval and overall survival has been slow. DNA measurements in specimens processed for histological examination has been described using microdensitometry of Feulgen-stained sections of paraffin-embedded tissue. This technique, however, is laborious and does not seem to have the resolving power of flow cytometry. Recently, Hedley et al. $(4,5)$ developed a method to process paraffin-embedded material for flow cytometric DNA determination. They were, however, unable to estimate ploidy levels owing to intersample variations in fluorescence intensities. In this chapter we describe a modification of this technique and an investigation of the methodological variations which give rise to inconsistent ratios of diploid $\mathrm{G}_{1}$ peaks of sample to reference standard. Furthermore, we present an alternative method of standarization that involves the admixture of nuclei from normal paraffin-embedded tissue of the same surgical specimen and processed under similar conditions as the primary tumor.

\subsection{Materials and Methods}

\section{Tissue}

Fresh unfixed tumor tissue was collected and transferred in RPMI 1640 supplemented with 10\% newborn calf serum (NCS), penicillin (100 units $/ \mathrm{ml}$ ), and streptomycin (100 units $/ \mathrm{ml}$ ). All samples were stained according to the method of Vindelov et al. (12). Part of the same tumor tissue and normal mucosa, taken from a remote part of the surgical specimen, were fixed in $10 \%$ neutral buffered formalin and embedded in paraffin by routine histotechnical procedure. Chicken red blood cells (CRBC) were 
frozen and stored according to the method of Vindelov et al. (11). CRBC samples were thawed and fixed with varying time intervals in $10 \%$ neutral buffered formalin.

\section{Preparation of Single Cells from Paraffin-Embedded Tissue}

A thin slice of paraffin-embedded tissue was scraped off the block surface with a scalpel. The tissue was cleared of paraffin with two changes of xylene for 1 hour at room temperature and rehydrated in a sequence of ethanol/xylene, $100 \%, 96 \%, 70 \%$ and $50 \%$ ethanol for 0.5 hour at room temperature. Samples were incubated in $0.25 \%$ trypsin (DIFCO) in citrate buffer $(3 \mathrm{mM}$ trisodiumcitrate, $0.1 \% \mathrm{v} / \mathrm{v}$ Nonidet $\mathrm{P} 40,1.5 \mathrm{mM}$ sperminetetrachloride, $0.5 \mathrm{mM}$ Tris, $\mathrm{pH} 7.6$ ) overnight at $37^{\circ} \mathrm{C}$. After vortexing and filtration over a nylon mesh $(50 \mu \mathrm{m})$ approximately $2-3 \times 10^{6}$ cells were stained according to the method of Vindelov et al. (12).

\section{Propidium lodide (PI) Saturation}

In order to study the PI saturation kinetics, formalin-fixed CRBC (24 h, room temperature) were processed for paraffinembedding. Single cells were prepared as described above and stained with various PI concentrations (final concentration: 100, $50,25,10,5$ and $2.5 \mu \mathrm{g} / \mathrm{ml}$ ).

\section{Measurement of PI Binding in Formalin-Fixed Cells}

CRBC were fixed for various time intervals in $10 \%$ neutral buffered formalin and stained for DNA content.

\section{Flow Cytometry}

Cellular DNA content was measured on a FACS IV cell sorter (Becton and Dickinson, Sunnyvale, CA) equipped with a $2 \mathrm{~W}$ argon ion laser (Spectra'Physics, model 164-01) operating at 488 $\mathrm{nm}$. Histograms of $10^{4}$ cells were recorded and the DNA index (DI) was calculated as the ratio of aneuploid to diploid $\mathrm{G}_{1 / 0}$ peak channel. Histograms with coefficients of variation (CV) less than $8 \%$ were considered of good quality. In case of overlap of diploid and hyperdiploid histograms the percentage of S-phase cells was not calculated. 


\section{$\overline{2} . \overline{2}$ Results}

When tissue, cleared of paraffin and rehydrated, was trypsinized overnight, a sufficient number of nuclei of acceptable quality for analysis of cellular DNA content were obtained. The fluorescence intensity of dip»oid nuclei, however, appeared to be less intense and more variable as compared to fresh, unfixed material. As a result the ratios of normal as well as malignant $G_{1}$ peaks to CRBC and TRBC peaks were inconsistent. Therefore, standardization in order to determine the ploidy level was almost impossible. One of the possible causes of this variability was considered to be nonsaturated dye uptake under the conditions used in the assay. Therefore, the PI uptake of fresh, formalin-fixed, and paraffin-embedded CRBC was investigated. As shown in figure 1, PI binding was saturable under the conditions tested, confirming stoichiometric binding. The fluorescence intensity appeared to be markedly decreased. Trypsinization of formalinfixed and paraffin-embedded $C R B C$ resulted in an almost twofold increase in fluorescence intensity. However, in comparison to fresh cells, the fluorescence intensity was still decreased. A

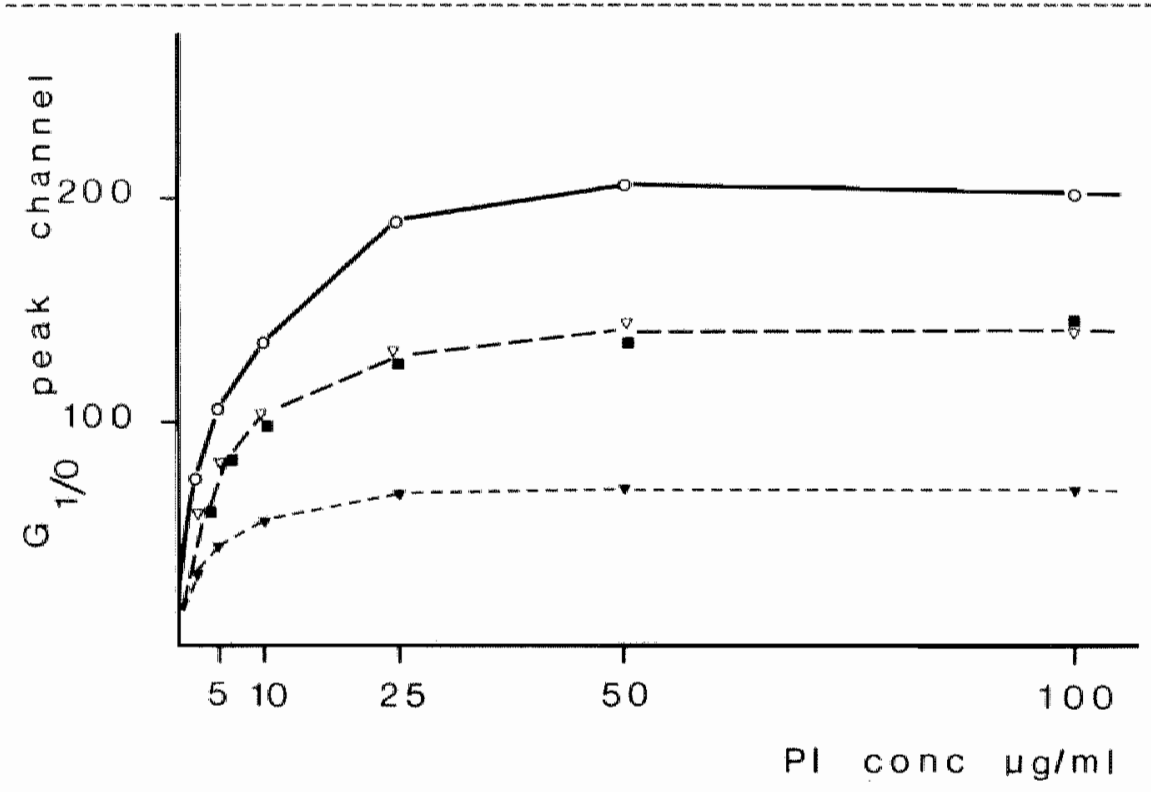

Figure 1 Pl saturation of CRBC after varjous treatments. CRBC were stained with increasing concemtrations of $P \rrbracket$ either fresh, unfixed (0), formalin-fixed with $(\nabla)$ or without $(\mathbf{v})$ overnight trypsinization, or formalin-fixed, paraffin-mbedded, rehydrated and trypsinized $1=1$. 
decrease in fluorescence intensity was also observed when other proteases were used in combination with or in addition to trypsin. Acid extraction of nucleoproteins (3) gave similar results. Since undersaturation of $\mathrm{Pl}$ binding could not account for inconsistent ratios of TRBC to diploid $\mathrm{G}_{1}$ peaks, we investigated the influence of the duration of fixation. The duration of fixation appeared to markedly influence the fluorescence intensity (table 1). For this experiment formalin-fixed CRBC with and without overnight trypsinization were mixed with fresh unfixed cells. Under both conditions, the relative lluorescence intensity was decreased after prolonged fixation. All other methodological variations had negligible effects on fluorescence intensity. For standardization purposes, normal diploid cells, CRBC and/or TRBC therefore appeared to be unsuitable, given the fact that the duration of fixation of sample material is not rigorously standardized. In an alternative approach to standardize DNA histograms, nuclear preparations from 14 paraffin-embedded colorectal tumor sam- ples were mixed with nuclei from tissue, taken from a normal part of the surgical specimen, and processed under identical conditions (figure 2). No significant differences between CV's of diploid $G_{1}$ peaks of separately stained samples and mixed populations could be observed (table 2). In this way we were able to calculate DNA indices of paraffin-

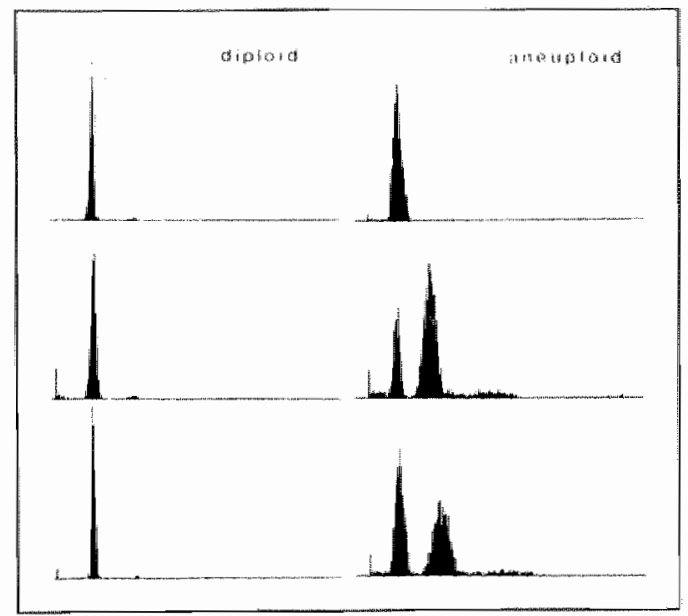

Figure 2 DNA histograms derived from one surgical specimen. Histogram from normal mucasa (topl. microscopically malignant tissue (middle), and a mixad population of bath (bottam) are showan. 
embedded tumor tissue. A comparison of ploidy level and percentage of $S$-phase cells in unfixed versus paraffin-embedded tissue is shown in figure 3. For both parameters statistically significant relationships were observed ( $r=0.9877$ and 0.5875$)$.

Table 1 Saturation of CRBC after verious treatments $(a, c)$.

\begin{tabular}{|c|c|c|}
\hline \multirow[b]{2}{*}{ lixallon tome } & \multicolumn{2}{|c|}{ 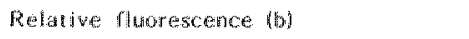 } \\
\hline & Formallo & Formalin a crypolnt \\
\hline $1 \mathrm{hi}$ & 0.36 & 0.82 \\
\hline $3 \mathrm{ll}$ & 0.34 & 0.73 \\
\hline $5 \mathrm{~h}$ & 0.35 & 0.67 \\
\hline $26 \pi$ & 0.32 & 0.60 \\
\hline $2 \mathrm{mon}$ & 0.28 & 0.42 \\
\hline
\end{tabular}

(a) PI fluorescence of CRBC after warlous fixation time intervals in formalin with and without overnight trypsinization.

(b) The relative fluorescemce intensity is expressed as the ratio of peath lluorescence of fresh to formalun-fixed CREC.

(c) All measurements were done in duplicate.

Table 2 Coefficients of wariation of diploid peaks of normal mucosa, lumor and mixed populations*.

\begin{tabular}{|c|c|c|c|}
\hline & $\begin{array}{l}\text { Nonnal } \\
\text { mucosás }\end{array}$ & Tumor & $\begin{array}{l}\text { Narmal mucosat } \\
\text { * tumar }\end{array}$ \\
\hline Me⿰п $\mathrm{CV}$ & 5.28 & 5.10 & 5.27 \\
\hline Standard Deviation & $\| .11$ & 1.17 & 1.06 \\
\hline
\end{tabular}

* Differences in CV for normal mucosa and tumor versus mixed population are not statistically significant (paired t-test, $p>0.30$, respectively $p>0.95$ ).
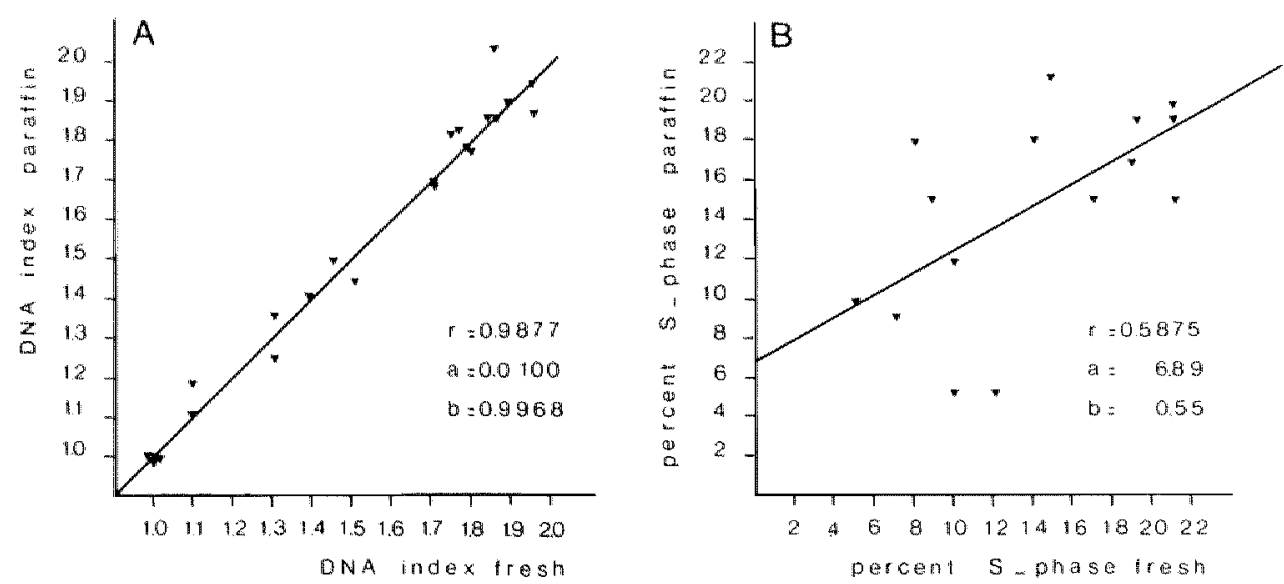

Figure 3 Correlation between ploidy levels (A) and percentage of S-phase cells (B) of rresth, unfixed, and paraffin-derived nuclei from 24 colorectal tunor specimens. Significant correlations for both $\mathrm{DI}(\mathrm{p}<0.001)$ and prolilerative actiwity $(\mathrm{p}<0.05)$ are observed. 


\section{$\overline{2} . \overline{3}$ Discussion}

Until recently flow cytometric measurements of cellular DNA content were limited to the availabillity of fresh unfixed tissue. Therefore, relationships between aneuploidy and disease-free interval or overall survival have to be studied in a prospective way and hence can only be established after considerable followup time. Recently, Hedley et al. $(4,5)$ developed the possibility of a retrospective approach by applying flow cytometry to nuclei released from paraffin-embedded tissue. We modified this technique and attempted to solve the problem of intersample variability in the intensity of DNA-derived fluorescence, observed when nuclei from paraffin-embedded tissue are mixed with unfixed reference standards.

As shown, PI fluorescence in formalin-fixed cells is decreased, depending on the duration of fixation. It is known that formalin cross-links proteins and stabilizes single-strand sequences of DNA (3). In this respect overnight trypsinization serves a dual purpose, because it releases cellular material from paraffin-embedded tissue and increases the fluorescence intensity by breaking up cross-linked nucleoproteins. In spite of variations in the level of PI fluorescence, dye uptake appears to be saturable, indicating that stoichiometric binding of the fluorochrome is obtained, i.e. a constant ratio of bound fluorochrome per amount of DNA. Hedley et al. $(4,5)$ observed similar effects, using 4-6Diamidino-2-Phenylindole (DAPI), a nonintercalating dye (2). These data suggest that loss of fluorescence owing to formalin fixation is not dye-specific but an inherent property of formalin-fixed chromatin.

Our observations confirm that an estimation of the ploidy level by admixture of fresh unfixed reference cells is not feasible as long as routine histological procedures are not rigorously stan dardized. As an alternative approach, we used paraffin-embedded normal tissue of the same patient, processed under identical conditions as the primary tumor. When a mixture of normal and tumor cells is stained, diploid nuclei can be identified by relative enrichment of one of the peaks in the DNA histograms. As shown in table 2, the resollution, as reflected in the CV, is not appreciably decreased, indicating that near-diploid tumors can also be identified. When paraffin-embedded blocks of normal tissue are not available, nonmalignant parts of the tissue can be excised from the blocks after microscopic examination. In contrast to the standardization procedure used by Hedley et al. (4, 5), which does not allow for unequivocal identification of the 
diploid $G_{\mathbb{1} / 0}$ peak, our method of standardization allows us to discriminate between aneuploid and diploid $G_{1 / 0}$ peaks and thereby to calculate DNA indices.

An excellent correlation $(r=0.9877)$ between DI's of 24 paraffinembedded and unfixed colon tumors was observed, confirming stoichiometric PI binding and justifying the use of normal tissue as reference standard. For an estimation of the proliferative activity this relationship, though statistically significant, was not optimal. As an explanation for this finding two factors should be considered. Overall loss of resolution of DNA histograms of paraffin-embedcled (mean $\mathrm{CV}=5$ ) as compared to unfixed (mean $C V=3.6$ ) nuclei reduces the accuracy of cell cycle analysis. More important, marked differences in proliferative activity are observed when multiple samples of the same unfixed tumor specimen are analysed separately ( $r=0.6354$ in 33 experiments, unpublished, and (6)), indicating the importance of sampling as a source of error. Therefore, both the overall loss of resolution and sampling differences may account for the relatively poor correlation between proliferative activity in unfixed versus paraffin-embedded nuclei.

Aberrations in nuclear DNA content are a well-known feature in human malignancies. Retrospective analysis of aneuploidy and cell cycle characteristics using paraffin-embedded tissue will accelerate the research for its prognostic implications. 


\section{References}

1. Baisch H, Otto U, Konig $K$, Kloppel $G$, Kollermanr $M$, Linden WA. DNA content of hurnan kiney carcinoma cells in relationt to histocytological grading. Br / Cancer 45: 878-886, 1982.

2. Coleman AH, Maquire MJ, Coleman IR. Mithramycin and 4'-6'Diamidino-2-Phenyldmolo (DAPIIDNA staning for fluorescence micraspectrophotometric measurement of DNA in nuclei, plasmids and virus particles. J Histochen Cytochem 29: 959-968, 1981.

3. Fraschini A, Pillicciari C, Biggiogera M, Manfredi Romanini MO. The ffect of dirferent tixatives on chromatun. Cytochemical and ultrastructural approaches. Histochem I 13: 763-779, 1981.

4. Friedlander ML. Hedley DW, Taylor IW, Russel P. Coates AS, Tatcersall MHW. In luence of cellular DNA content on survival in adwanced owariar cancer. Cancer Res 44: 397-400, 1984.

5. Hedey DW, Friedander ML, Taylor W. Rugg CA. Musgrove EA. Method for analysis of cellular DNA content of paraffin-embedded pathological material using flow cytometry. I Histochem Cytochem 31: 1333-1335, 1983.

6. Lamber $M$. Intratumor heterogeneity of thymidime labeling index in primary breast cancer: the reason for its fallure as a prognostic indicator. 3ra EORTC Breast Cancer Working Conference, 1983, abstract no. Vl 20 .

7. Olszewski W., Darzynkiewicz Z, Rosen PP, Schwartz MK, Melamed MR. Flow cytometry of breast carcimoma: relation of DNA ploidy level to histology and estrogen receptors. Cancer 48: $980-984$, 1981.

8. Raber MN, Barlogie B, Latreille J, Bedrossian C, Fritsche H, Blurnenschein G. Ploidy, proliferative activity and estrogen receptor content in human breast cancer. Cytometry 3: $36-41,1982$.

9. Rognam TO, Thorud E, Elgjo K, Brandzaeg P, Orjasaeter H, Nygaard K. Lange-bowel carcinomas with different ploidy, related to secretory component, IgA, and CEA in epithelium and plasma. Br $J$ Cancer $45: 921-934,1982$.

10. Teodori $L$, Tirindelli-Danesi $D$, Mauro $F$, DeVida $R$, Uccelli R, Botti $C$, Modini $C$, Nervi $C$, Stipa S. Non small cell lung carcinoma: tumor characterization on the basis of flow cytometrically de termined cellular heterogeneity. Cytometry 4: 174-183, 1983.

11. Vindelov LL, Christensen I], Keiding N, Spang-"Thomsen M, Nissen NI. Long-term storage of Samples for flow cytometric DNA andysis. Cytometry 3 : $317-322,1983$.

12. Vindelov LL, Christensen IJ. Nissen NI. A detergent trypsin method for the preparation of nuclei for flow cytometric DNA analysis. Cytometry 3: 323-327, 1983. 
PLOIDY LEVEL AND PROLIFERATIVE ACTIVITY IN COLORECTAL CARCINOMA: CORRELATION WITH CLINICOPATHOLOGICAL AND IMMUNOHISTOCHEMICAL PARAMETERS 


\section{Introduction}

Flow cytometry allows the measurement of deviations in the total cellular DNA content. Using this technique, aneuploidy has been detected in 50 to $90 \%$ of the solid tumors in man (1). In several tumor types, including colorectal carcinoma, aneuploidy has emerged as an indicator of unfavourable prognosis (1-9). Traditionally, the stage of the tumor has emerged as the most important criterium to identify patients with different clinical courses in colorectal carcinoma (10). Grading, which is mainly a descriptor of biological characteristics of the individual tumor cells, has been shown to correlate with a more malignant behaviour of the tumor. Undifferentiated or poorly differentiated tumors show a more unfavourable prognosis as compared to moderately or well differentiated tumors $(11,12)$. The degree of differentiation can also be analysed using immunohistochemistry. In this way, alterations in the expression of cell products, which are associated with various differentiated cell types in colonic mucosa such as secretory component (SC), serotonin and mucin can be studied, as well as the expression of tumor associated markers such as carcinoembryonic antigen (CEA) and gastrointestinal antigen (Ca 19-9) (13).

It has been shown that alterations in the expression of functional markers or tumor associated markers bear prognostic information. Tumors lacking immunoreactivity for SC (11) or for CEA (14) behaved more agressively. Also the presence of serotonin immunoreactivity (15), uniform expression of Ca 19-9 (16) and the predominance of sialomucins over sulphomucins (17) were related to a poorer survival.

Since colorectal tumors, as they become more malignant, are more frequently aneuploid and simultaneously show loss of differentiation characteristics, we certain patterns of antigen expression and/or prognostically relevant pathological or clinical parameters.

\subsection{Materials and Methods}

\section{Tissues}

The material used for the present study was derived from a multicenter prospective controlled surgical trial. This study was conducted between January 1979 and January 1982 and compared the no-touch approach of colorectal carcinomas with the conventional surgical approach, follow-up parameters being diseasefree interval and overall survival. Pertinent information including 
age, preoperative CEA levels, localization, stage of extension, tumor shape, angioinvasive growth and histological grade as well as follow-up data on local recurrence and metastases were collected according to protocol and computerized. In addition, in the same period 76 patients, who could not be entered in the trial because of age, stage or technical failures of the no-touch procedure, were included in this study, bringing the total number of patients to 350 . Clinicopathological data of these patients were collected and computerized in the same way as for the trial patients. All pathologic reports, histologic slides and paraffin blocks were collected in our institution and reviewed with regard to stage and grade by two independent observers.

\section{Pathology}

Details of staging and grading have been described elsewhere (18). Briefly, for staging purposes the Turnbull modification (19) of the original Dukes' classification was employed. The degree of differentiation was rated according to criteria adapted from Blenkinsopp et al. (20).

Tumors of the cecum and the ascending colon were classified as right sided tumors. Tumors of both flexures were assigned to the transverse colon. Left sided tumors comprised those in the colon descendens and the sigmoid. The rectosigmoid and rectal tumors were taken together as well.

Tumors were classified according to their macroscopical shape into sessile, ulcerative and polypoid tumors.

\section{Immunohistochemistry}

5 micron sections of the primary tumor were subjected to inmunostaining for secretory component (SC), serotonin, CEA and Ca 19-9. Mucin Production was examined using the High-IronDiamine/Alcian Blue stain (HIDAB) (21), distinguishing between sulphated and sialated mucins. The source of the antibodies applied in indirect immunoperoxidase procedures and the methods employed have been reported previously $(11,14,15,18)$. Immunoreactivity of the various antigens was semiquantitatively scored as positive when over $80 \%$ of the tumor cells expressed the antigen, as negative when less than $5 \%$ of the neoplastic cells displayed immunoreactivity, and as focally positive, when in between 5 and $80 \%$ of the carcinoma cells showed expression of the antigen. An exception was made for serotonin reactivity. Tumors were scored positive, when serotonin immunoreactive 
cells were encountered and negative when no immunoreactivity was observed.

\section{Flow cytometry}

279 cases were available for flow cytometric analysis. Ploidy levels were measured on nuclei derived from paraffin-embedded tissue as described previously (22). Small tissue fragments were dissected from the blocks, dewaxed in xylene and rehydrated according to routine histological procedures. Nuclei isolated from the tissue fragments by trypsin digestion, were stained with propidium iodide and analyzed on a FACS IV cell sorter (Becton \& Dickinson, Sunnyvale, CA). A tumor with a single $G_{1}$ peak was considered to be diploid whereas an additional $G_{1}$ peak indicated the presence of aneuploidy. The DNA index was calculated as the ratio of the $G_{1}$ peak with the highest DNA content to the $G_{1}$ peak with the lowest DNA content. In 194 cases we were able to calculate the percentage of S-phase cells, in the other cases this was technically impossible due to overlapping populations.

\section{Statistics}

A chi-square analysis for association was used for interpretation of the cross tabulations between the ploidy level/percentage Sphase cells and clinicopathological and immunohistochemical parameters.

\subsection{Results}

The frequency distribution of the DNA indices is depicted in figure I. Since the degree of aneuploidy was not correlated with any of the variables, the tumors were classified as diploid $(37.6 \%)$ or aneuploid $(63.4 \%)$, the latter category including tumors with multiple stemlines (3.9\%) (23). Figure 2 shows the frequency distribution of the percentage of S-phase cells. Tumors were designated as high proliferative when the percentage of S-phase cells exceeded $13 \%$, corresponding to the $95 \%$ confidence level for normal mucosal epithelium. All other tumors were scored as low proliferative.

No correlation was observed between DNA index or proliferative activity and age, preoperative CEA levels, stage, grade or angioinvasive growth (table 1). Tumors in the left hemicolon, ulcerative tumors and tumors which presented with anal blood loss, 


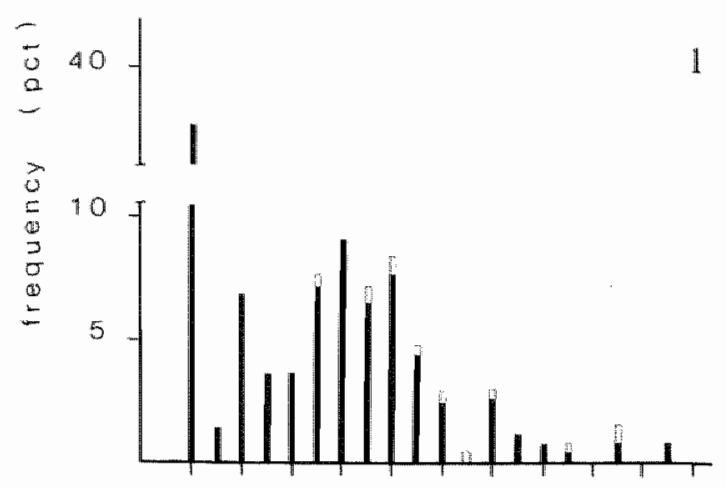

$\begin{array}{lllllllllll}10 & 1.2 & 1.4 & 1.6 & 1.8 & 20 & 2.2 & 24 & 26 & 28 & 3.0\end{array}$

DNA index

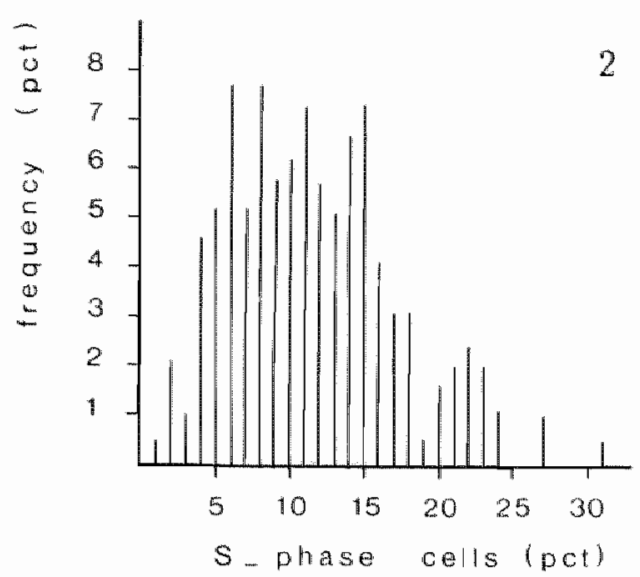

Figure 1 Frequency distribution of DNA indices in 279 colorectal carcinomas. Open bars represent tumors with multiple stemlines.

Figure 2 Frequency aistribution of percentage $S$ phase cells in 194 colorectal carcinomas.

Table $\quad$ Relationship between ploidy level/percentage S phase cells and clinicopenthological and immunohistochemical parameters in 279 colorectal carcinomas.

P values

DNA index \% 5 phase cells

$\begin{array}{lll}\text { localization } & 0.008 & 0.0002 \\ \text { anal blood loss } & 0.005 & \text { n.s. } \\ \text { angioinvasive growth } & \text { n.s. } & \text { n.s. } \\ \text { stage } & \text { n.s. } & \text { n.s. } \\ \text { grade } & \text { n.s. } & \text { n.s. } \\ \text { age } & \text { n.s. } & \text { n.s. } \\ \text { plasma CEA levels } & \text { n.s. } & \text { n.s. } \\ \text { secretory component (SC) } & \text { n.s. } & \text { n.s. } \\ \text { serotonin } & \text { n.s. } & \text { n.s. } \\ \text { mucir composition } & 0.007 & 0.009 \\ \text { CEA } & 0.0009 & 0.0113 \\ \text { Ca 19-9 } & \text { n.s. } & \text { n.s. } \\ \text { \% S phase cells } & 0.0001 & \\ \text { (chi square) } & & \end{array}$


were more frequently aneuploid (tables 2, 3, 4). Expression of CEA and the absence of mucin production were associated with aneuploidy (tables 5 and 6), whereas no correlation was found between DNA index and expression of SC, Ca 19-9 or serotonin. Proliferative activity was correlated with the same parameters as the DNA index except for the presence of anal blood loss. This is explained by the strong association between these two parameters, as shown in table 6 .

\section{$3 . \overline{3}$ Discussion}

Rognum et al. (24) showed in a semiquantitative analysis that more extensive SC expression occurs in diploid colorectal carcinomas. Furthermore, they observed a statistically significant correlation between ploidy level and CEA immunoreactivity, aneuploid tumors expressing higher levels of CEA. Our results on 279 colorectal tumors are in close agreement with those of Rognum et al. (24). Although we did not scored the immunoreactivity semiquantitatively, we were able to show that CEA is preferentially expressed in aneuploid tumors. However, no association between SC expression and ploidy level was observed in our material. In general, significant correlations between the histologically assessed degree of differentiation and ploidy level did not exist. We only found that diploid tumors show more mucin production and more frequently do not express CEA.

There are several explanations for our inability to demonstrate a correlation between the expression of differentiation and ploidy level. Firstly, these features were scored independently, markers which may introduce a sampling bias. Secondly, alterations of the tumor cell phenotype as well as flow cytometrically detectable aneuploidy are most likely secondary phenomena, not directly responsible for the malignant behaviour of the tumor cells. Evidence is accumulating that more subtle alterations of the genome, especially involving oncogenes, may be more directly related to the malignant behaviour of tumor cells (25). Our data suggest that high proliferative activity is an intrinsic property of aneuploid tumors. However, due to the admixture of unknown numbers of normal, non-proliferating leucocytes or fibroblasts, the observed proliferative activity of diploid tumors may be an underestimate.

A striking result is the statistically significant difference in incidence of aneuploidy between tumors in the right and those 
Table 2 Ploidy level and localization.

\begin{tabular}{|c|c|c|c|c|}
\hline & $\begin{array}{l}\text { right sided } \\
\text { quimber } \\
\text { (perent }\end{array}$ & 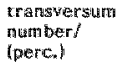 & $\begin{array}{l}\text { feft sided } \\
\text { menmberl } \\
\text { fperc.) }\end{array}$ & $\begin{array}{l}\text { rougal } \\
\text { numbriber }\end{array}$ \\
\hline dipl & $31(29.5)$ & $16(15,3)$ & $58 \div 55,2)$ & 105 \\
\hline amevploid & $27 \| 15.5 \%$ & $17(9.81)$ & 130174.70 & 174 \\
\hline cotat? & $58(20.8)$ & $33(11.8)$ & $188 \quad 67.41)$ & 279 \\
\hline
\end{tabular}

chli square peid.0079

Table 3 Ploidy level and tumor shape.

\begin{tabular}{|c|c|c|c|c|}
\hline & $\begin{array}{l}\text { polypous } \\
\text { number } \\
\text { (perc.) }\end{array}$ & $\begin{array}{l}\text { sescile } \\
\text { number } \\
\text { tperc. }\end{array}$ & $\begin{array}{l}\text { wlcerative } \\
\text { number/ } \\
\text { (permot) }\end{array}$ & $\begin{array}{l}\text { tot al } \\
\text { num ber }\end{array}$ \\
\hline diploid & $20(19.8)$ & $2 耳\{20.8\}$ & $60 \quad[5,5,4]$ & 000 \\
\hline aneuploid & $19(10.9)$ & $27\{0.5,5\}$ & $128(73.6)$ & 17 米 \\
\hline wotal & $39: 14.21$ & $4 B(07.5)$ & $188(68.3)$ & 275 \\
\hline
\end{tabular}

chi squatite pro.0xg8

Table 4 Ploidy level and blood loss.

\begin{tabular}{|c|c|c|c|}
\hline & $\begin{array}{l}\text { not present } \\
\text { number/ } \\
\text { (percil }\end{array}$ & $\begin{array}{l}\text { present } \\
\text { number/ } \\
\text { (perce) }\end{array}$ & $\begin{array}{l}\text { totat } \\
\text { number }\end{array}$ \\
\hline $\begin{array}{l}\text { diploid } \\
\text { arietpplolid } \\
\text { total }\end{array}$ & $\begin{array}{r}31(77.1) \\
110(62.2) \\
191(6.8 .5)\end{array}$ & $\begin{array}{l}2.4(22.9) \\
64(36.9) \\
88 .(34.5)\end{array}$ & $\begin{array}{l}105 \\
174 \\
279\end{array}$ \\
\hline
\end{tabular}

chis square per 0.05

Table 5 Ploidy level and CEA expression.

\begin{tabular}{|c|c|c|c|}
\hline & $\begin{array}{l}\text { negatiwe } \\
\text { nurntber } \\
\text { (perce) }\end{array}$ & $\begin{array}{l}\text { positive } \\
\text { number } \\
\text { (perch) }\end{array}$ & $\begin{array}{l}\text { total } \\
\text { number }\end{array}$ \\
\hline tipto & $18 \llbracket 18.0 j$ & $92(82.0)$ & 100 \\
\hline aneuplotold & (8) 4.8 & $160(95.2)$ & 168 \\
\hline \{01 tof & $26 \quad 9.7\}$ & 242003 & 2689 \\
\hline
\end{tabular}

chi square $p=0.0009$

Table 6 Plordy level and mucin production.

\begin{tabular}{|c|c|c|c|c|c|}
\hline & $\begin{array}{l}\text { negiatline } \\
\text { numberer/ } \\
\text { ipersol }\end{array}$ & 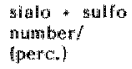 & 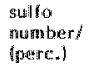 & 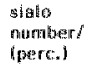 & 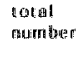 \\
\hline dip & $49\{150,5\}$ & $2: 121.61$ & 105.6 & $=9.31$ & 97 \\
\hline aneuploid & 113168.5 & $2:(12.7)$ & $13,7.9 y$ & $18(10,9)$ & 165 \\
\hline Hot a 1 & $162(61.9)$ & $42(16.0)$ & 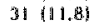 & $27(10.54)$ & 161 \\
\hline
\end{tabular}

chis square $p=0.0065$

Table 7 Ploidy level and percentage of 5 phase cells.

\begin{tabular}{|c|c|c|c|}
\hline & $\begin{array}{l}513 \% \\
\text { rumberf } \\
\text { fpere- }\end{array}$ & 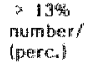 & $\begin{array}{l}\text { colal } \\
\text { number }\end{array}$ \\
\hline $\begin{array}{l}\text { diploid } \\
\text { ane uptoid } \\
\text { total }\end{array}$ & $\begin{array}{rr}82 & 165,61 \\
6 & (8,7) \\
88 & (45,4)\end{array}$ & $\begin{array}{r}43(54,4) \\
63(91.3) \\
106(54.6)\end{array}$ & $\begin{array}{r}125 \\
69 \\
194\end{array}$ \\
\hline
\end{tabular}


in the left hemicolon. This finding suggests that different factors may be involved in the evolution of carcinomas in the right and the left hemicolon. This is also supported by the finding of Matek et al. (26) in demonstrating that $50 \%$ of the colorectal adenomas occur in the right hemicolon, whereas only $25 \%$ of the carcinomas are located there. In addition, Hagitt (27) reported that rectal carcinomas that arise in adenomas are more deeply invasive than carcinomas in other locations. Furthermore, Rothberg (28) observed that elevated expression of the myc oncogene occurs more frequently in tumors of the left side than in tumors of the right side. The correlations between ploidy level and other clinical and pathological features, such as anal blood loss and shape of the tumor, reflect the strong correlation between aneuploidy and the localization of the tumor.

In conclusion, as shown by others, loss of differentiation characteristics and aneuploidy are both associated with a more agressive behaviour of colorectal tumors, which would be in accordance with the theory of tumor progression as proposed by Nowell (29). However, this study does not support the contention of aneuploidy being simply related to either the extent of disease or the degree of differentiation, assessed morphologically or immunohistochemically. 


\section{References}

1. Friedlander $M L$, Hedley DW, Taylon IW. Clinical and biological significance of aneuploidy in human tumours, If Clin Patholl 37: $961-974,1984$.

2. Amitage NC, Robins RA, Evans DF, Tumer DR, Baldwin RC, Hardcastle ID. The infuence of tumor cells DNA abnormalities on survival in colorectal cancer. Br \ Surg 72: 828-830, 1985 .

3. Atkins $N B$, Kay R. Prognostic significance of modal DNA value and other factors in malignant tumours, based on 1465 cases. Br J Cancer 40: $210-211,1979$.

4. Aler $G$, Eriksson $E$, Azavedo $E_{y}$ Caspersson $T$, Wallgren A. Prognostic significance of nuclear DWA content in manmary adenocarcinomas in humans. Cancer Res 44: 394-396, 1984.

5. Barlogie B, Johnston DA, Smallwood L, Raber MN, Maddox AM, Latreile J, Swartzendruber DE, Drewinko B. Prognostic implications of plody and proliferative activity in human solid umors. Camcer Gener Cytogenet 6: 17-28, 1982.

6. Kokal W, Scheibani K. Terz J, Harada R. Tumor DNA content in the progrnosis of colorectal carcinoma. JAMA 255: $3123-3127,1986$.

7. Schute B, Reynders MMJ, Wiggers T, Arends JW, Volowics L, Bosman FT, Blijham GH. The prognostic significance of DNA content and proliferative actiwity in large bowel carcinoma. Cancer Res (accepted).

8. Volm M, Drings, P, Mattern J, Sonka I, Vogt-Moykopf I, Wayss K. Prognostic significance of DNA patterns and resistance predictive tests in ron small lung carcinoma. Cancer 56: 1396m 1403, 1985.

9. Wolley RC, Schreiber K, Koss LG, Karas M, Sherman. A. DNA distribution in human colon carcinom ma and its relationship to clinical behaviour. I Nat Cancer Inst 69: 15-22, 1982,

10. Phillips RKS, Hittinger R, Blesowsky L, Fry IS, Fielding LP. Large bowel cancer survival pathology and its relationship to survival. Br J Surg 71: 604-610, 1984 .

11. Arends WW, Wiggers T, Thijs CT, Verstignen K, Swaen GI, Bosman FT. The value of secretory component (SC) immunoreactivity in diagnosis and prognosis of colorectal carcinomas. Am I Chin Pathol 82: $267-274,1984 a$.

12. Jass JR, Atkin WS, Cazick J, Bussey HJR, Morson BC. Northover JMA, Todd IP. The grading of rectal cancer: historical perspectives and a multivariate analysis of 447 cases. Histopathology 10 : $437-459,1986$.

13. Arends JW, Bosman FT, Hilgers J. Tissue antigens in Iarge bowel carcinoma. Biochim Biophys Acta $780: 1-19,1985$.

14. Whgers T, Arends JW, Verstijnen K, Moerkerk PM, Bosman FT. Prognostic signiflcance of CEA immunoreactivity patterns in large bowel carcinoma tissue. Br J Cancer 54: 409-414, 1986.

15. Arends JW, Wiggers T, Verstijnen K. Bosman FT. The occurrence and clinicopathological signifi. cance of serotonin immunoreactive cells in large bowel carcinoma. J Pathol 149: 97-102, 1986a.

16. Arends JW. Wiggers T, Verstijnen C, Hilgers J. Bosmen Fl. Gast rointestinal cancer-bsaciated antigen (GICA) immunoreactivy in cotorectal carchoma in pelation to patient surviwal. Int I Cancer 34: 193-196, $1984 \mathrm{~b}$.

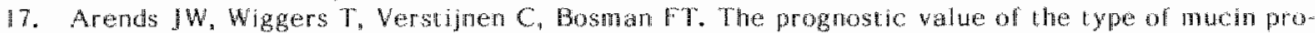
duction in large bowel carcinoma. J Clin Pathol (in press).

18. Arends IW, Wiggers T, Schutte B, Thils CT, Verstijnen K, Hilgers J, Blijham GH, Bosmant. Monoclonal ant body (1116 NS 19-9) defined monosialoganglioside (CICA) in colorecual cancinoma in relation to stage, histopathology and DNA flow cytometry. Int J Cancer 32: 289-293, 1983.

19. Turnbull RB, Kyle K, Watson $F R$, Spratt J. Cancer of the colon: the influence of the gno-tondy isolation technique on survival rates. Ann Surg 168: 420-427, 1967.

20. Btenkinsopp WK, Steward Brown S, Blesovski L, Kearney G, Fielding L. P. Histopathology reponing in large bowel cancer. I Clim Pathol 34: 509-513, 1981.

21. Spicer $\$ 5$. Henson $1 G$. Methods for localizing mucosubstances in epithelial and connechut lissu. Methods Arch Exp Pathol 2: 78-\#12, 1967.

22. Schut te B, Reynders MM】, Bosman FT, BHijham GH. Flow cytometric determination of DNA photy level in nuclei isolated from parafinmembedded tissue. Cytometry $6: 26-30,1985$.

23. Hiddeman $W$, von Bassewlt a $\mathrm{DB}$, Kleinemeier HJ, Schulte-Brochterbeck E, Hauss SA, Limgeman B, Buchner $\mathrm{T}$, and Grundmann E. DNA stemline heterogeneity in colorectal cancer. Cancer 58: 258m 26\%. 1986

24. Rognum TO, Thorud E, Elgjo K, Brandtzagg P, Orjasaeter I. Nygaard K, Lange bowel carcinomes with different plotiy, related to secretory component, IgA, and CEA in epithelium and plasma. Br I Cancer, $45: 921-934,1982$.

25. Siamon Dd, de Kernian JB, Verna JM, Cline MJ. Expression of cellular oncogemes in human malignancies. Science 224: $256-262$, 1984.

26. Matek W, Hermanek P. Demling L. Is the adenoma-carcinoma sequence contradicted by the differ ing location of colorectal adenomas and carcinomas? Erdoscopy 18: 17-19, 1986. 
27. Haggitt RC, Glotzbach RE, Solfer EE, Wruble LD Prognosilic factors in colorectal carcinomas arising in adenomas: implications for lesions removed by endoscopic polypectomy. Gastroenterology $89: 328-336,1985$.

28. Rothberg PG, Spandarfer JM, Erisman MD, Staroscik RN, Sears HF, Petersen RO, Astrin SM. Ewidence that c-myc expression defines two genetically distinct forms of colorectal adenocarcinoma. $\mathrm{Br}\rfloor$ Cancer 52: 629-632, 1985.

29. Nowell PC. The clonal evolution of tumour cell populations. Acquired genetic lability permits stepwise selection of variant sublines and underlies tumour progression. Science $194: 23-28,1976$. 
COMPARISON OF PHENOTYPIC AND GENOTYPIC FEATURES IN PRIMARY LARGE BOWEL CARCINOMAS AND LYMPH NODE METASTASES 


\section{Introduction}

Most human tumors are known to consist of multiple subpopulations differing in genotypic and phenotypic characteristics (1). From animal experiments there are indications that metastasis is a selective process, in which some clones have the ability to metastazise whereas others have not $(2,3)$.

It is conceivable that clones with and without metastatic potential differ in genotypic and phenotypic characteristics and that as a consequence of the selection, metastasized clones show a more restricted spectrum of these features. Description and comparison of genotypic and phenotypic characteristics between primary tumors and metastases may therefore be of value to type tumor cells with metastatic potential and eventually even allow the identification of these cells in a primary tumor. To investigate this hypothesis the expression of several antigens associated with normal and neoplastic large intestinal epithelium was compared in an analysis of phenotypic characteristics on a series of primary large bowel carcinomas and their lymph node metastases. To this effect two antigens known to be particularly associated with adenocarcinoma, CEA (4) and $\mathrm{Ca} 19-9$ (5), as well as the relevant products of the three differentiated cell types, secretory component (SC) (6) for the columnar cells, mucin for the goblet cells and serotonin for the enterochromaffin cells were chosen. In addition, we compared flow cytometric data on DNA content as a genotypic feature and S-phase cell percentage.

\subsection{Materials and Methods}

\section{Materials}

The material of this study was derived from a multicentre prospective controlled clinical trial conducted to compare the Turnbull no-touch surgical procedure with the conventional approach. Details on the design of the study have been reported previously (8, 9). From a total of 311 patients included in this trial 87 Dukes' $C$ cases were available for the study.

\section{Antigen Expression and Mucin Histochemistry}

One $5 \mu \mathrm{m}$ section of routinely formalin-fixed and paraffin-embedded tissue sample of the primary tumor and one section of a regional lymph node metastasis were subjected to immunostaining for SC, Ca 19-9, serotonin and CEA. The source of the antibodies applied in the immunoperoxidase procedure and the de- 
tails of the methods employed have been reported previously ( 8 , $9,10,111$.

Briefly, the SC antiserum was purchased from Dakopatts (Copenhagen, Denmark) and used in an unlabeled peroxidase/antiperoxidase technique after trypsinization of the sections. The antiserum to serotonin was obtained by immunization of rabbits with a formalin-condensed serotonin/BSA complex and employed in an indirect immunoperoxidase procedure (12). The CEA-reactive monoclonal antibody, Parlam 1, has been generated in our institution and the characteristics of this monoclonal antibody have been extensively reported (13).

The Ca 19-9 monoclonal antibody was kindly provided by Dr. Z. Steplewski from the Wistar Institute, Philadelphia, U.S.A. Both the CEA reactive and the $\mathrm{Ca} 19-9$ monoclonal antibodies were applied in an indirect immunoperoxidase technique. Immunoreactivity of the different antigens was semiquantitatively scored as positive, when over $80 \%$ of the tumor cells expressed the antigen, negative, when less than $5 \%$ of the neoplastic cells displayed immunoreactivity and focally positive, when in between 5 and $80 \%$ of the carcinoma cells showed antigen expression. Mucin production was examined using the High-iron-diamine/Alcian blue stain (14) allowing the distinction between sulphated and sialated mucins. Tumors were designated according to the type of mucin observed, as sulphomucin tumors, when predominantly sulphomucins were detected, sialomucin tumors in case of predominant sialomucin detection and mixed sialo/sulphomucin tumors when both mucin types were observed.

\section{Flow Cytometry}

In 44 of 87 Dukes" $C$ cases sufficient material was available for flow cytometric analysis. Ploidy levels and percentage of S-phase cells were measured on nuclei isolated from paraffin-embedded tissue as described previously (15).

Briefly, small tissue fragments were dewaxed in xylene and rehydrated in a graded series of ethanol.

Nuclei isolated by trypsin digestion of the tissue fragments were stained with propidium iodide and analyzed on a FACS IV cell sorter (Becton \& Dickinson, Sunnyvale, CA, USA). A tumor with a single $G_{1}$ peak was considered to be diploid, whereas evidence of an additional $G_{1}$ peak was taken to indicate the presence of aneuploidy. The DNA index was calculated as the ratio of the $G_{1}$ peak with the highest DNA content to the $G_{1}$ peak with the 
lowest DNA content. The proliferative activity was calculated by counting the number of cells with a DNA content between $G_{1}$ and $\mathrm{G}_{2} / \mathrm{M}$ values. In cases with less than $30 \%$ admixture of diploid cells the percentage of aneuploid S-phase cells was calculated without corrections for the presence of diploid S- and $\mathrm{G}_{2} / \mathrm{M}$-phase cells.

\section{$\overline{4} . \overline{2}$ Results}

\section{Phenotypic Features}

In 45 cases $(52 \%)$ no difference was observed between primary tumors and their lymph node metastases with regard to the expression of CEA, Ca 19-9, SC and serotonin as well as the production of mucin. The remaining 42 cases $(48 \%)$ showed a difference in expression of one to three antigens and mucin production. These results are summarized in table 1 . The lymph node metastases were uniformly rather small, allowing the analysis of an entire cross section of the lesion in one section. In discrepant cases additional sections of the primary tumor were analyzed for intratumor heterogeneity. Heterogeneity between different sections, however, never exceeded that between different areas within one section.

In tables 2 and 3 expression patterns of the antigens and the production of mucin are further detailed. It appeared that the mode of expression of the individual antigens and mucin production most frequently is identical in primary tumors and lymph node metastases, the percentages of concurrence being 94,75 , 83, 94 and 74 for CEA, Ca 19-9, SC, serotonin and mucin type respectively.

Table 1 Difference in antigen expression and/or mucin prodiction between primary large bowel carcimomas and lymph node metastases.

Number of differing antigens* number of cases percentage

$\begin{array}{rrr}0 & 45 & 52 \\ 1 & 26 & 30 \\ 2 & 13 & 15 \\ 3 & 3 & 3\end{array}$

*including mucin production. 
CEA was observed in almost all tumors and their metastases. The five cases in which a difference in expression was noted, demonstrated more expression in primary tumors in two cases and more expression in metastases in three cases.

Serotonin appeared to be only scarsely expressed in primary tumors and even less in metastases. In three cases, however, the antigen was detectable in both the primary tumors and their metastases.

Ca 19-9 and SC demonstrated a comparable distribution of positive, focally positive and negative tumors over the tumor population and a comparable number of cases in which the expression differed between primary tumors and metastases. No striking discrepancy was observed in the number of cases expressing more of the antigens in either primary tumors or metastases. The type of mucin production also appeared to be remarkably constant. In seven mucin producing primary tumors no mucin was detectable in the metastases, but in seven cases in the metastases mucin was seen despite its absence in the primary tumors. In nine cases loss of production of either sulphomucin or sialomucin was found in the metastatic lesion. In three cases more than one metastasis could be studied. No differences in antigen expression were found between different metastases from one original tumor with exception of one case in which SC was positive in one metastasis but only focally expressed in another metastasis.

\section{Genotypic Features}

In the majority of cases (33 of 44 ) the DNA index was identical in primary tumors and lymph node metastases, as indicated by the highly significant correlation shown in figure 1 . In three cases the primary tumor was diploid, but the metastasis aneuploid. In three other cases the primary tumor was aneuploid, but the metastasis diploid. In four cases the primary tumor contained two aneuploid stemlines of which only one recurred in the metastasis. Strikingly enough only the stemline with the lowest DNA index recurred in the metastasis. In one case an aneuploid primary tumor resulted in an aneuploid metastasis with a different DNA index. Figure 2 shows the correlation of percentage Sphase cells between primary tumors and metastases. Only those cases were considered in which no difference in ploidy level was observed. A statistically significant correlation $(\mathrm{p}<0.001)$ was found between the S-phase fractions of primary and metastatic 

bowel carcinomets.

\begin{tabular}{|c|c|c|c|c|c|c|c|}
\hline \multirow{3}{*}{$\frac{\text { primary/metastasis }}{\text { negative/negative }}$} & \multicolumn{6}{|c|}{ number of cases } & \multirow[b]{2}{*}{ Difference in pattem } \\
\hline & CEA & $\mathrm{Ca}$ & $19-9$ & SC & & serotomin & \\
\hline & 5 & 27 & & 33 & & 79 & \\
\hline focal/focal & $994 \%$ & 30 & $75 \%$ & 31 & $83 \%$ & $394 \%$ & identical pattern \\
\hline positive/posicive & 68 & 8 & & 8 & & 0 & \\
\hline positive/negative & 0 & 0 & & 0 & & 0 & \\
\hline positive/focal & $12 \%$ & 4 & $10 \%$ & 2 & $9 \%$ & $06 \%$ & more expression \\
\hline focal/negative & 1 & 5 & & 6 & & 5 & in primary tumor \\
\hline negative/positive & 0 & 0 & & 3 & & 0 & \\
\hline negative/focal & $04 \%$ & 6 & $15 \%$ & 1 & $8 \%$ & 0 & more expression \\
\hline focal/positive & 3 & 7 & & 3 & & 0 & in metastasis \\
\hline
\end{tabular}

Table 3 Type of mucin production (Su=sulphomucin, $\mathrm{Si}=$ sialomucin) in primary and metastatic large bowel carcimomas.

primary/metastasis* Number of cases Differences of pattern/type

\begin{tabular}{|c|c|c|}
\hline negative/negative & 29 & \\
\hline $\mathrm{Su}+\mathrm{Si} / \mathrm{Su}+\mathrm{Si}$ & 12 & \\
\hline Su/Su & $1474 \%$ & identical pattern/type \\
\hline $\mathrm{Si} / \mathrm{Si}$ & 9 & \\
\hline$S u+S u / S u$ & 3 & reduction in one type \\
\hline $5 \mathrm{Su}+\mathrm{Si} / \mathrm{Si}$ & 5. $10 \%$ & of mucin in either primary \\
\hline $\mathrm{Su} / \mathrm{Su}+\mathrm{Si}$ & 1 & or metastasis \\
\hline Su/negative & 4 & \\
\hline Si/negative & $28 \%$ & mucin present in puimary, \\
\hline Su. Si/negative & $\|$ & absent in metastasis \\
\hline negative/su & 3 & \\
\hline negallive/Si & $\| 8 \%$ & mucin present in metastasis \\
\hline negalive/Su + Si & 3 & absent in primary \\
\hline
\end{tabular}

* only the observed combinations are compiled 

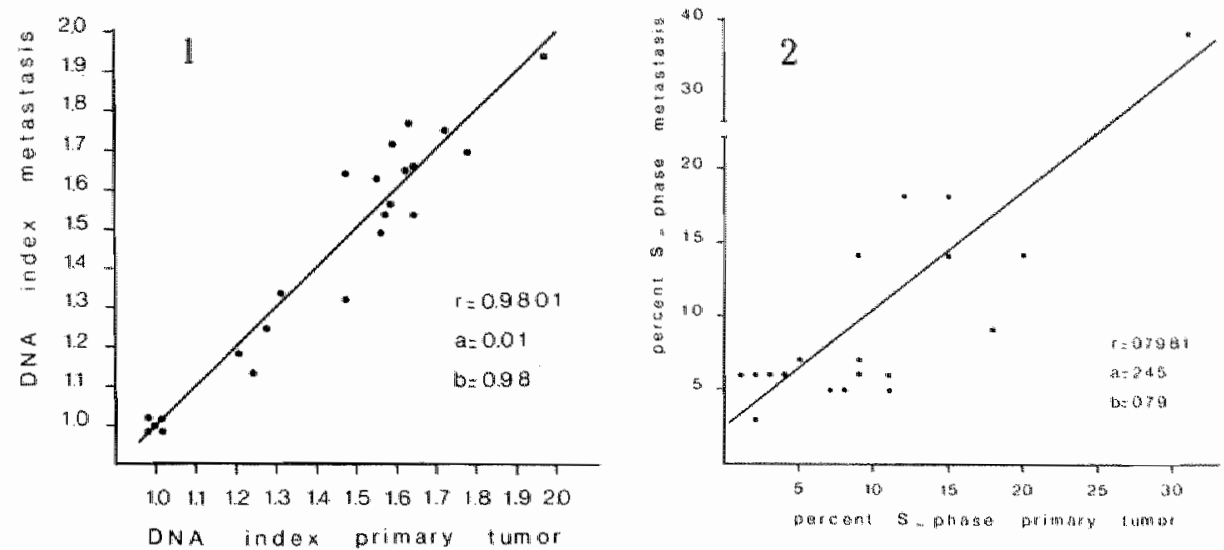

Figtare $\|$ Correlation between ploidy lewels in primary tumors and netastases (n-33). For conwe nience only five of fifteen diploid tumors are shown. A highly significant correlation (p 0.0011 was observed.

Figure 2 Correlation between percentage of S-phase cells of primary tumors and metastases (n= 191. A significant correlation $(\mathrm{p}=0,001)$ was observed.

tumors, indicating that in general metastatic tumors are not more actively proliferating than primary tumors.

\subsection{Discussion}

Recent studies in animal models suggest that metastasis is not a random, but a selective process, in which only a limited number of clones from a heterogeneous primary tumor are involved ( 2 , 3). If metastases are of monoclonal origin, the genotypic and phenotypic characteristics of such lesions would be restricted to those of the metastasizing clonogenic cell.

It has been shown, however, that metastases, though clonal in origin, during progression diverge to reform phenoty pically heterogeneous populations (16). Our finding, that primary tumors and their metastases usually share the same phenotypic features, is in line with this observation. The various lines of differentiation in colorectal carcinomas, which correspond with those in normal colonic epithelium, apparently reemerge in the lymph node metastases. These may either not be clonal or if they are clonal, are subject to rapid phenotypic divergence. In either case it is clear that phenotypic characteristics, such as expression of antigens or production of mucins, cannot be used as evidence in studies concerning the pathogenesis of lyph node metastases, which is not in keeping with Kellokumpu's observations (17). This may be different, however, in regard of the genotype. Although flow cytometric DNA analysis allows only a rough 
estimate of genotypic variability the fact that 40 of our 44 cases contained only one stemline indicates that gross genotypic divergence is a much less frequently occurring phenomenon in colorectal cancer. We therefore chose the genotype as a second tumorcell characteristic.

In 33 cases the DNA index of the primary tumor was identical to that of the lymph node metastasis. All those cases, however, had only one stemline and were therefore not heteroclonal from a genotypic point of view. In four cases however, the primary tumor contained two stemlines, of which only one recurred in the lymph node metastasis. This finding would support the selective nature of the metastatic process. In seven cases a primary tumor with a single stemline gave rise to a lymph node metastasis with a different DNA index. In these cases the variant (metastasizing) cells could have belonged to a minority population which escaped detection by flow cytometry. An alternative explanation could be that they emerged during the early stages of the development of the metastasis, which however, then might have shown more than one stemline.

In summary our results show that phenotypic characteristics of colorectal carcinoma cells cannot be used to study the pathogenesis of lymph node metastases. Our flow cytometric observations are compatible with the hypothesis that metastasis is a selective clonal event. Which mechanisms are involved in the process of selection, however, remains unclear. 


\section{References}

1. Woodruff MFA. Cellular heterogeneity in tumors. Br J Cancer 47: $589-594,1983$.

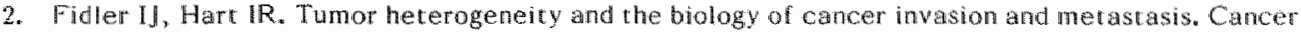
Res 38: 2651-2660; 1979.

3. Fidler [1, Hart IR. The dewelopment of biological diversity and metastacio potential in malignam neoplasms. Oncodev Biol Med 4: 161-176, 1982.

4. Gold $P$, Freeman 50 . Specific carcinoembryonic antigens of the lnuman digestive system. I Exp Med 122: 467-481, 1965 .

5. Koprowski H, Steplewski Z, Mitchell K, Herlyn M, Herlyn D, Fuhrer P. Colorectal carcinoma ambigens detected by hybridoma artabodies. Som Cell Genet 5: 957-972, 1979.

6. Tourville DR, Adler RH, Blenenstock J, Tomasi TB. The human secretory im mughlobulin system: immunohistological localization of A, secrecory "piece" and lactoferrin in normat human tissues. I Exp Med 129: $411-426,1969$.

7. Wells CA, Taylor SM, Cuello AC. Argentafin and argyrophil reactions and serotonin content of endocrine tumors. J Clin Pathol 38: 49-53, 1985.

8. Arends JW, Wiggers Th, Thijs CT, Verstijnen CPHJ, Swaen GJV, Bosman FT. The walue of secretory component (SC) immumoreactivity in diagnosis and prognosis of colorectal carcinomas. Am II Clin Pathol 82: 267-274, 1984.

9. Arends JW, Wiggers Th, Schutte B et al. Monoctonal antibody (II 6 NS 19-9) defined monosialom ganglioside (GICA) in colorectal carcinoma in relarion to stage, histopathology and DNA flowcytometry. Int I Cancer 32: 289-293, 1983.

10. Arends JW, Wiggers Th, Verstignen CPHJ, Bosman FT. The occurrence and clinicopathological significance of serotonin immunoreactive cells in large bowel carcinona. I Pathol 149:97-102, 1986 .

11. Wiggers Th, Arends JW, Verstijmen CPHJ, Moerkerk PM, Bosman FT. Prognostic significance of CEA immunoreactivity patterns in large bowel carcimoma tissue. Br J Cancer 54: 409-4 $14,1986$.

12. Verhofstad AAJ, Steinbusch HWM, Joosten HWJ, Penke B, Varga J, Goldsten M. Im munocytoxhe. mical localization of noradrenaline, adrenaline and serotonin. In: Polak JM, van Noorden $\mathrm{S}$ leds.). Immunocytochemistry: practical applications in pathology and biology. Bristol, U.K. Wright and Sons, pp. $\mathbb{4} 43-160,1983$.

13. Verstinen CPHJ. Arends JW, Moerkerk PTM, wanaar S, Hilgers J, Bosman F T. CEA specifichty of CEA reactive monoclonal antibodies. Immunochemical and immunocy tochemical studies. Anticancer Res 6: $97-104,1986$.

14. Spicer SS. Diamine methods for differentiating mucosubstances histochemically. J Histochem Gy tochem 13: 211-234, 1965.

15. Schute B, Reynders MM], Bosman FT, Blijham CH. Flow cytomeric determination of DNA ploty level in nucles isolated from paraffin-embedded tisste. Cytometry 6: 26-30, 1985.

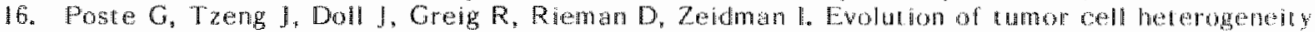
during progressive growth of individual lung metastases. PNAS 79: 6574-6578,1982.

17. Kellokumpu IH. Differences in lectin reactivities of cellular gllycoconjugates between prinary human colorectal carcinomas and their metasrases. Cancer Res. 46: 4620-4625, 1986. 


\section{Introduction}

Large bowel carcinoma is one of the most common neoplasms, rating second only to carcinoma of the lung. It carries a considerable mortality with an overall 5 year survival of around $50 \%$. Adjuvant chemotherapy and radiotherapy have not been able to change survival rates significantly. Promising results have been obtained, however, with local chemotherapy by infusion into the portal vein in colonic cancer (1) and combined chemoradiotherapy in rectal cancer (2). These adjuvant treatments may cause considerable morbidity and are therefore best studied in well defined patient populations with a less favourable prognosis. The most important prognostic factor in large bowel carcinoma is the Dukes' stage. Additional features, related with prognosis, include the degree of differentiation (3) and marker profiles (4, $5,6)$. Furthermore, aberrations in ploidy level are a well recognized feature of human solid tumors with an incidence of aneuploidy ranging from 50 to $90 \%$ (7). In certain tumor types (8-14), including colorectal carcinoma (15-18), analysis of DNA content appears to offer prognostic information.

In this study we have evaluated the prognostic significance of ploidy levels in a large series of large bowel carcinomas, which were included in a prospective randomized trial comparing two different modalities of surgical treatment. The aim was to obtain an additional biological determinant which may help to segregate patients with similarly staged tumors into subgroups with different prognosis.

\subsection{Materials and Methods}

Tissue

Blocks of paraffin-embedded colorectal carcinoma tissue were collected from a multicenter prospective controlled surgical trial, carried out from January 1979 through January 1982. This trial was conducted to compare the results of the no-touch isolation technique (9) with those of conventional surgical approach. In 279 of 350 cases sufficient material for flow cytometry was obtained. For this purpose also cases with nonresectable tumors or distant metastases were included. In all cases material from the primary tumor was used for analysis.

\section{Staging}

In this trial patients were staged according to the Turnbull modification of the original Dukes" classification. Of this series 
of patients $22,41,31$ and $7 \%$ were classified as Dukes" A, B, C and $D$ respectively (19).

\section{Flow Cytometry}

The method used has been fully described elsewhere (20). Briefly, tissue was scraped from a paraffin-embedded tissue block, dewaxed and rehydrated in a sequence of xylene and a graded series of ethanol. The tissue was then digested with trypsin and the obtained nuclei were stained for DNA content according to the method of Vindelov et al. (21). A tumor with a single $G_{1}$ peak was considered to be diploid, whereas evidence of an additional $G_{1}$ peak indicated the presence of aneuploidy. The DNA index was calculated as the ratio of the $G_{1}$ peak with the highest DNA content to the $G_{1}$ peak with the lowest DNA content. The proliferative activity was calculated by counting the number of cells with a DNA content between $G_{1}$ and $G_{2} / M$ values. In cases with less than $30 \%$ admixture of diploid cells, the percentage of aneuploid S-phase cells was calculated, without corrections for the presence of diploid $S$-and $\mathrm{G}_{2} / \mathrm{M}$-phase cells.

\section{Statistics}

For the calculation of disease-free and overall survival, product limit survival analysis was performed using the Biomedical Computer Program P-Series (BMDP). Calculations of the significance of observed differences were made using the log rank test (Mantel Cox) and the generalized Wilcoxon test (Breslow). Patients with adjacent organ invasion or distant metastases (Dukes' D) were included in this material for the calculation of overall survival rates, but this category of patients was excluded from the calculation of disease-free interval limiting the total number of cases to 260 . To date, the mean duration of follow-up is 51.9 months (range 44.1-60.0 months).

If possible, histological or cytological evidence was obtained to confirm metastatic or recurrent disease. Characteristic changes on chest X-ray, liver scan (repeatedly) or abdominal CT-scan preferably in combination with a raised carcinoembryonic antigen (CEA) level were accepted as well. Abnormal liver function tests or CEA level raised without a strongly suspected anatomical site were not accepted as a proof of recurrent disease. 


\subsection{Results}

Figure 1 represents the frequency distribution of ploidy levels in 279 cases of large bowel carcinoma. A characteristic bimodal distribution of aneuploidy is observed with tumors having either a near-diploid mode or a triploid-tetraploid mode. In a minority of cases $(3.9 \%)$ the tumor was multiploid. Since the degree of aneuploidy appeared not to be significantly correlated with survival, for further analysis tumors were classified as diploid $(37.6 \%)$ or aneuploid $(63.4 \%)$, the latter comprising all cases with one or more $G_{1}$ peak(s) additional to the diploid $G_{1}$ peak. In 194 cases we were able to calculate the percentage of $\mathrm{S}$-phase cells. The frequency distribution is shown in figure 2. For further analysis tumors were classified as low proliferative or high proliferative with a cutoff point at 13\% S-phase cells, being the $95 \%$ confidence level for normal mucosal epithelium.

Product limit survival analysis demonstrated a borderline significant association between tumor ploidy and survival (generalized Breslow, $p=0,0689$; generalized Savage, $p=0.0336)$. Patients with diploid tumors demonstrated a 75 th quantile survival of 49.8 months versus 35.9 months for patients with aneuploid tumors (figure 3). After stratification for staging, Dukes' C cases showed a statistically significant association between tumor ploidy and overall survival (generalized Breslow, $\mathrm{p}=$ 0.0224 ; generalized Savage, $p=0.0110$ ) with a 75 th quantile survival of 47.9 and 28.9 months for patients with diploid and aneuploid tumors respectively (figure 4). In Dukes" stages A, B and $D$ different ploidy levels did not correlate with prognosis.
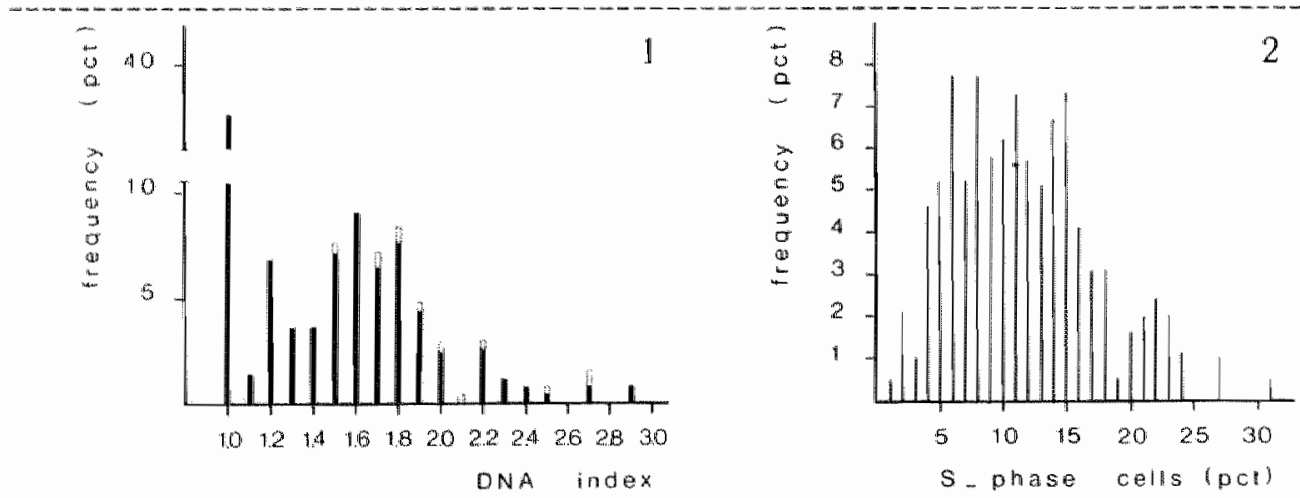

Figure 1 Frequency distribution of DNA index in 279 cases of large bowel carcinoma. Open bars represent tumors with multiploid stemlines.

Figure 2 Frequency distribution of the percentage of S-phase cells in 194 cases of large bowel carcinoma. 


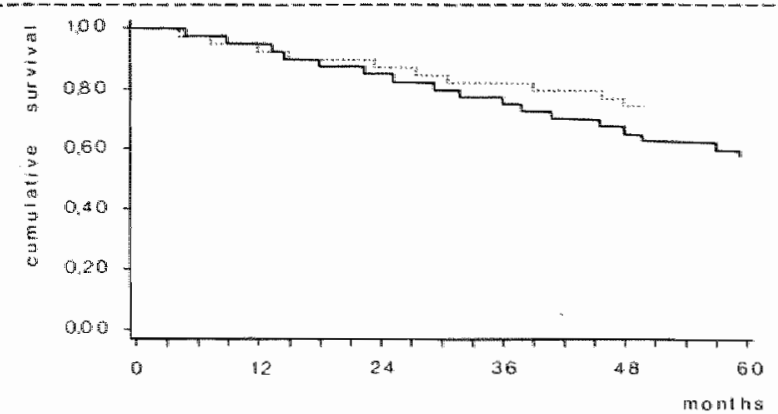

Figure 3 Life table analysis demonstrating overall survival for pacients win diploid (.....) (n = 105 ) and aneuploid (-) tumors $(n=174) . p=0.0689$ (generalized Breslow), $p=0.0336$ (generalized Savage).

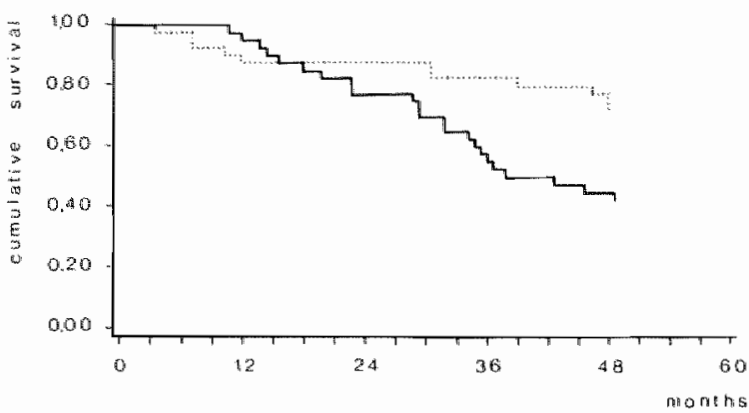

Figure 4 Life table analysis for Dukes' C stage of disease, demonstrating survival for patients with diploid $\{\ldots . . .$.$) ( n=31)$ and aneuploid $(-)$ tumors $(n=55), p=0,0224$ (generallzed Breslow), $p=0.0110$ (generalized Savage).

Figure 5 demonstrates the relation between ploidy level and disease-free interval. Patients with diploid tumors showed a longer disease-free interval (75th quantile of 52.3 months) as compared to patients with aneuploid tumors (75th quantile of 22.2 months). This difference was significant (generalized Breslow, $p=0.0107$ ) generalized Savage, $p=0.0089)$, even if the stages $\mathrm{A}, \mathrm{B}$ and $\mathrm{C}$ were taken together.

Product limit survival analysis showed an association between proliferative activity and survival, similar to ploidy level. Overall survival for patients with low proliferative tumors was longer than for patients with high proliferative tumors (generalized Breslow, $p=0.0451$; generalized Savage, $p=0.0320$ ) (figure 6). After stratification for Dukes' stage this association was again only significant in Dukes" C disease (figure 7) with a 75th quantile survival time of 38.9 and 18.0 months for patients with low and high proliferative tumors respectively (generalized Breslow, $p=0.0121$; generalized Savage, $p=0.0093)$. 


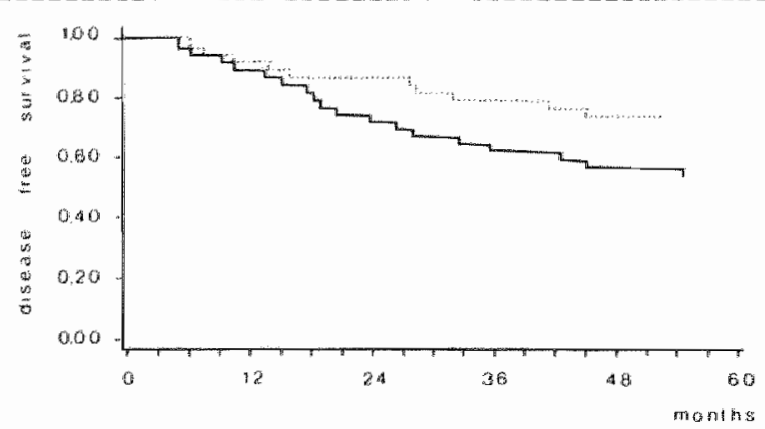

Figure 5 Disease-free survival for patients with diploid $(\ldots \ldots).(n=98)$ and aneuploid $(-)$ tumors $(n=160), p=0.0107$ (generalized Breslow), $p=0.0089$ (generalized Savage).

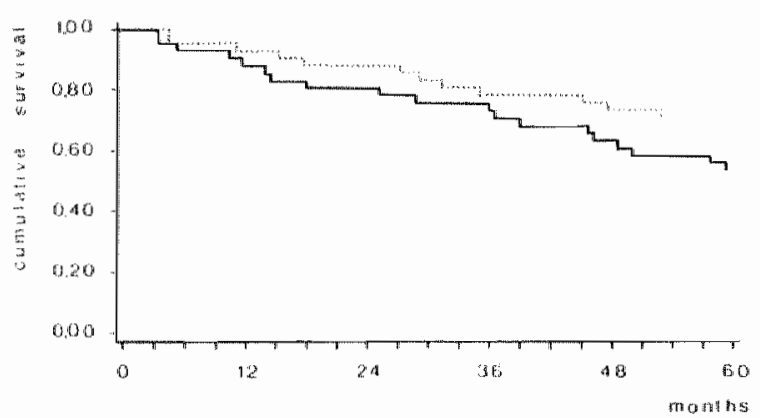

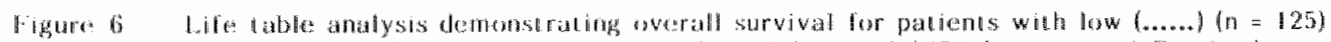

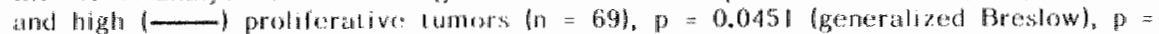
0.0920 fgeneralizad Savage\%.

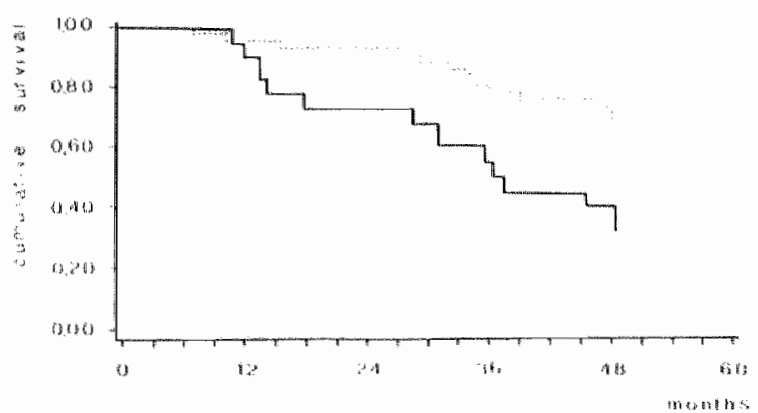

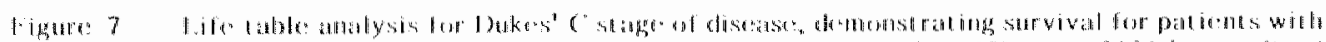

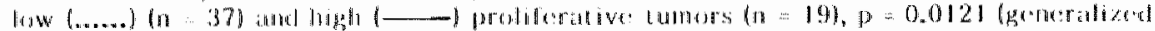

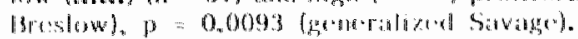




\section{$\overline{5} . \overline{3}$ Discussion}

The DNA content of colorectal tumors cells as assessed by flow cytometry of propidium iodide stained nuclei from paraffin-embedded tissue appears to add important prognostic information to that obtained from staging. In fact, of patients with diploid Dukes' $C$ tumors approximately $25 \%$ expired within 4 years in contrast to $60 \%$ of the patients with a hyperdiploid DNA content, in the majority of cases due to recurrent tumor growth. Several studies have been published concerning aneuploidy in colorectal carcinoma, which generally show similar frequency distributions of aneuploid DNA content $(7,22,23)$. In one report (15), specifically dealing with the relation between ploidy and prognosis, Dukes' $C$ cases represented 21 of 33 patients. The remarkably better survival of patients with diploid tumors in that study may therefore in part be due to an overrepresentation of Dukes' $\mathrm{C}$ cases, in which we found a strong association between ploidy level and survival. This observation seems to be confirmed by recent publications with smaller numbers of patients $(16,17,18)$.

Any effect of DNA content on the survival of Dukes' A and B patients is necessarily limited to those cases in which the tumor was not radically excised and, in view of the high cure rate in those stages, may need very large numbers to be demonstrated. In Dukes' D patients the tumor load is high and the rapidly downhill course is apparently not appreciably influenced by variability in DNA content of the tumor cells (24). Reliable assessment of tumor extent is difficult in patients with locoregionally advanced disease. From a biological as well as a therapeutical point of view in this group of patients, stage independent variables which might predict recurrent and therapy resistant disease, would be usefull. The DNA content appears to be one such variable $(9,10,11,12,13,14)$. Apparently with aneuploid tumors the chance of dissemination beyond the regional lymph nodes is higher or, alternatively, such micrometastases will demonstrate a more accellerated growth. The shape of the disease-free survival curve, showing separation after 18 months which is maintained throughout the next 3 years, suggests the former explanation to be valid.

It can not be excluded that the similar outcome of survival analysis in relation to proliferative activity and ploidy level reflects the strong correlation between the two parameters. Such a correlation can parlly be explained by technical reasons, since due to the admixture of normal cells in DNA histograms of 
diploid tumors the percentage of S-phase cells may be spuriously low. This contention is supported by the results of Meyer et al. (25) in showing that $\left[{ }^{3} \mathrm{H}\right]$-thymidine labeling indices in colorectal carcinomas are not correlated with prognosis. Cell kinetic studies, using bromodeoxyuridine incorporation in vivo, might clarify whether or not a difference in growth characteristics exists between diploid and aneuploid tumors and thus ascertain its potential prognostic importance.

Tumors with a diploid cellular DNA content do not necessarily have a normal karyotype $(26,27)$. Flow cytometric DNA analysis does not allow to detect small or balanced chromosomal aberrations. Nevertheless, this technique does distinguish tumors with a normal from those with an abnormal DNA content easily and with a high success rate. Therefore, as long as a more precise determination of structural and functional abnormalities of the genome remains time consuming and cumbersome, flow cytometric DNA analysis provides the clinician with important prognostic information. 


\section{References}

1. Taylor $I_{\text {, Machin }} \mathrm{D}$, Mullert M. Troter $G$, Cooke T, West C. A randomized controlled trial of adjuvant portal vein cytotoxic perfusion in colorectal cancer. Bu I Surg 72: 359-363. 1985.

2. Gaserointestinal Tumor Study Group. Prolongation of the disease-free inferval in surgically traated rectal carcinoma. $N$ Engl J Med 312: 1405-1412, 1985.

3. Jass JR, Atkin WS, Cuzick J, Bussey HJR, Mason BC, Northover JMA, Todd bP, The grading of rectal cancer: historical perspectives and a multwariate analysis of 447 cases. Histopathology 10 : $437-459,1986$.

4. Arends IW. Wiggers T, Thijs. CT, Verstijnen K, Swaen GJ, Bosman FT. The walue of secretory component (SC) immunoreact ivity in diagnosis and prognosis of colorectal carcinomas. Am $\mathrm{J}$ Clin Pathol 82: 267-274, 1984.

5. Arends $\mathrm{JW}$, Wiggers $\mathrm{T}$, Verstijnen $\mathrm{K}$, Bosman $\mathrm{FT}$. The occurrence and clinicopathological signilim cance of serotonin immunoreactive cells in large bowel carcinoma. J Pathol 149: 97-102, 1986.

6. Wiggers T, Arends JW, Verstijnen $K$. Moerkerk PM, Bosman FT. Prognostic significance of CEA immunoreactivity patterns in large bowel carcinoma tissue. $\mathrm{Br} J$ Cancer 54: 409-414, 1986.

7. Friedlander ML. Hedley DW, Taylor IW. Clinical and biological significance of aneuploidy in human tumours. I Clin Pathol 37: $961-974.1984$.

8. Barlogie B, Johnston DA, Smallwood L, Fraber MN, Maddox AM, Latreille J, Swartzendruber DE, Drewinko B. Prognostic implications of ploidy and prollferative activity in human solid tumors. Cancer Genet Cylogenet 6: $17-28,1982$.

9. Atkin NB, Kay R. Prognostic significance of modal DNA value and other factors hn mallignant tumours, based on 1465 cases. Br ॥ Cancer 40: 210-221, 1979.

10. Auer G, Eriksson E, Azavedo E, Caspersson T, Wallgren A. Prognostic significance of muclear DNA content in mammary adenocarcinomas in humans. Cancer Res 44: 394-396, 1984.

11. Carlson PB, Thornthwate JT, Woolley TW, Sugarbaker EV, Seclinger D. Prognostic indicators including DNA histogram type, receptor content and staging related to breast pathent survival. Cancer Res 44: 4187-4196, 1984.

12. Friedlander ML, Hedley DV, Taylor IW, Russel P, Coates AS, Tattersall MMV. Influence of cellulat DNA content on survival in adwanced ovarian cancer. Cancer Res 44: 397-400, 1984.

13. Volm M, Drings P, Mattern J, Sonka J. Vogt-Moykopl I, Wayss K. Prognostic significance of DNA patternis and resistance predictive tests in non small cell lung carcinoma. Cancer 56: 1396-1403, 1985.

14. Abe S, Makimura Itabashi K, Nagai T, Tsuneta Y, Kawakani Y. Prognostic significance of nuclean" DNA content in small cell carcinoma of the lung. Cancer 56: 2025-2030, $\| 985$.

15. Wolley RC, Schreiber K, Koss LG, Karas M, Sherman A. DNA distribution in human colon carcinomas and its relationship to clinical behawiour. JMCJ $69: 15-22,1982$.

16. Melamed MR, Warren EE, Banner $P$. Abbe J], Kressler G, Darzynkiewics $Z$. Flowcylonetry of colorectal carcinoma with three year rollow-up. Disease of the Collon \& Rectum 29: 184-186. 1986.

17. Armitage NC, Robins RA, Evans DF, Tumer DR, Baldwin RC, Hardcastle JD. The intluence ol umor cells DNA abnormalities on survival in colorectal cancer. Br I Surg 72: 828-830, 1985.

18. Kokal W. Scheibani K. Ter2 J. Harada R. Tumor DNA content in the prognosis of collorect cinoma. IAMA 255: 3123, 1986.

19. Turnbull RB JR, Kyle $K$, watson FR, Sprat I. Cancer of the collon: the influence of the no-louch isolation technique on surviwall rates. Ann Surg 16f; $420-427, \| 967$.

20. Schutce B, Reynders MMJ, Bosman FT, Blitham GH. Flow cycometric determination of DNA ploidy level in nuclei isolated from parafrinembedded tissue. Cytometry 6: 26-30, 1985.

21. Nindelov LL, Christensen 1], Nissen NI. A detergent trypsin method for the preparation of nuclei for flowcytometric DNA analysis. Cytometry 3: $323-327,1983$.

22. Hidemann won Bassewir DB, Klenemeler HI, Schulte-Brochterbeck E, Hauss I, Limgerribln B, Buchner 17, Grundmann E. DNA stemline heterogeneity in colorectal cancer. Cancer 58: 258-263. 1986.

23. Rognum TO, Thorud E, Elgjo K, Brandtzaeg P, Orjasaeter H, Nygara K. Large-bowel carcinomas with different ploidy, related lo secretory component, IgA, and CEA in epithellum and plasma. Br 1 Cancer 45: 921-933, 1982,

24. Finar PJ, Quirke P, Dixon MF, Dyson JED, Giles GR, Bird CC. Is DNA aneuploidy a good prognostic indicator in patients with advanced colorectal cancer? Br J Cancer 54: 317-320. 1986.

25. Meyer JS, Prioteau PG. S-phase fractions of colorectal carcinomas related to pathological and clinical reatures. Cancer 48: 1221-1228, 1981 .

26. Tribukatt B, Granbergu Ohman I, Wijkstrom H. Flow cytometric DNA and cytogenetic studies in human tumors: a comparison and discussion of the differences in modal values obtained by the trwo methods. Cytometry 7: 194-199, 1986. 
27. Petersen $\mathrm{SE}_{*}$ Fritmich $\mathrm{U}$. A comparison between llow cytometric ploidy investigation and chromosome andysis of 32 human colorectal tumors Cytometry 7 : $307-312,1986$. 
LIMITATIONS OF DNA FLOW CYTOMETRIC ANALYSIS: THE RATIONALE FOR DYNAMIC CYTOKINETIC STUDIES 


\section{Determination of S-phase fractions}

Several methodological considerations underline the relative inaccuracy of S-phase estimations as a descriptor of cellular growth. Firstly, there is a mathematical inaccuracy of resolving the various phases of the cell cycle from a single histogram due to overlapping $\mathrm{G}_{1} / \mathrm{S}$ and $\mathrm{G}_{2} / \mathrm{M}$ populations. More importantly, in case of multiple stemlines within one tumor, mathematical models are to be developed to selectively segregate mixed populations with different ploidy levels. Secondly, admixtures of unknown quantities of normal diploid cells can cause an underestimation of proliferative activity of diploid tumors. A promising development is the simultaneous staining of DNA content and intermediate filament proteins, with which epithelial cells can be discriminated from infiltrating leucocytes and fibroblasts with a high degree of specificity $(1,2)$. Furthermore, admixture of normal cells and also the proliferative activity might not be randomly distributed giving rise to sampling bias. Thirdly, measurements which are based on a static approach, such as the determination of the relative number of S-phase cells at a given point of time, do not allow a detailed description of a dynamic process such as cellular growth. No information is obtained about the growth rates and the size of the non-proliferating compartment. Those are the parameters which determine the production rate of tumor cells (3).

\section{6.i Methods for the measurements of cell kinetic parameters}

To obtain dynamic information such as cell cycle traverse time (Tc), S-phase transit time (Ts) and growth fraction (GF), a detectable precursor can be incorporated into the reduplicating DNA of a proliferating cell. Sofar, radiolabeled precursors have been mostly used in cyto- or histoautoradiographic techniques (4). By counting the fraction of labeled mitoses at different time intervals after labeling, the phase transit times and the cell cycle traverse time can be calculated according to mathematical models. The autoradiographic technique and cell counting are laborious and time consuming. In addition the use of radiolabeled chemicals in patients is subject to ethical considerations. Recently, Gratzner (5) developed an immunocytochemical method for the detection of bromodeoxyuridine (BrdU) incorporated into the DNA of proliferating cells. BrdU is a synthetic analog of thymidine. Monoclonal antibodies can be raised which react with BrdU without cross-reacting with the other nucleotides. In an 
indirect immunocytochemical technique, cells which have incorporated BrdU can be labeled with a fluorochrome and simultaneously the DNA can be counterstained (6). Flow cytometry then allows the simultaneous measurement of incorporated BrdU as well as the DNA content on a single cell level. In this way the cohort of labeled cells can be followed through the cell cycle. Recently, Begg et al. (7) described a method for the estimation of the S-phase duration and the potential doubling time using a single sample analysis. The method is based on the assumption that the mean DNA content of the BrdU labeled cells during progression through $S$-phase increases linearly. This movement of cells is expressed as a relative movement (RM) which shows a linear increase in time, starting with a value of 0.5 directly after pulse labeling. When the time after pulse labeling is known the duration of the S-phase can be calculated through extrapolation of RM to 1.0 at which time all labeled cells would have reached $\mathrm{G}_{2} / \mathrm{M}$-phase.

\section{$\mathbf{6 . 2}$ Clinical significance}

The application of BrdU labeling with subsequent immunocytochemical detection has several advantages. Firstly, as discussed above, this approach could describe the cellular growth of a tumor more accurately and therefore add to the pretreatment prognostic information, which may be important for clinical research. Secondly, with this technique problems related to the cytokinetic resistance of tumors can be addressed. New drugs. after being developed in preclinical models, are lested as single agents and in varying combinations with or without other therapeutic modalities on a largely empyrical basis. Detailed knowledge of the cytokinetic characteristics of specific tumor types in combination with knowledge concerning the mode of action of specific cytostatic agents could lead to a more conceptional approach.

\section{$\overline{6} . \overline{3}$ Outline of the study}

To date $\left[{ }^{3} \mathrm{H}\right]$-thymidine has frequently been applied as a DNA precursor in cell kinetic studies. There are several limitations to this technique. Firstly, the technique requires the use of radioactive precursors, limiting the application for in vivo studies in patients due to ethical considerations. Secondly, the detection 
methods are laborious and time consuming. Thirdly, often multiple biopsies are needed to measure cell cycle parameters. Because of these drawbacks cell kinetic analyses in cancer research have been limited. By introducing BrdU as a precursor molecule for incorporation into cellular DNA, with subsequent immunocytochemical detection, many of these drawbacks can be overcome. Several studies indicate that BrdU or iododeoxyridine (IdU) can be administered to patients without severe toxic effects $(8,9)$. The methods for detection of BrdU are rapid and relatively simple, giving identical information as obtained by using [3H]-thymidine incorporation. Furthermore, by combining BrdU and DNA staining, kinetic information can be obtained using a single biopsy, making this approach extremely valuable for in vivo cell kinetic research. We therefore raised a monoclonal antibody against BrdU and developed techniques for its detection. In chapter 7 the production and characteristics of the anti-BrdU monoclonal antibody are described. Furthermore, an improved and highly sensive method for bivariate BrdU/DNA analysis using llow cytometry is presented. This method also allows the detection of labeled cells in ethanol fixed tissue fragments. In this way multicentre clinical trials using in vivo BrdU or ex vivo incorporation for cell kinetic studies are facilitated. In chapter 8 the influence of tissue fixation on anti-Brdu immunoreactivity is studied.

Chapter 9 describes a method for the immunohistochemical delection of proliferating cells in combination with the detection of antigen expression. Apart from topographical detection of proliferating cells, this method allows to address more fundamental questions concerning the relationship between differentlation and proliferation.

Chapter 10 the method presented by Begg et al. (7), using a single sample andysis for the estimation of the S-phase duration and the potential doubling time, is evaluated in colorectal cancer cell lines grown in vitro and in vivo. In addition, the cytokinetic parameters are discussed in relation to the biological behaviour of the same cell lines grown as xenograft in nude mice. Chapter 11 contains a brief summary of chapters 7 to 10 and a general discussion. 


\section{References}

1. Ramaekers FCS, Beck H, Vooys GP. Hermen CJ. Flowcytometic analysis of mixed cell population: using intermediate flament antibodies. Exp Cell Res 153: 249-253, 1984.

2. Feitz WFJ, Beck HLM, Smeets AWGB, Debrune FMI. Vooys GP. Herman CI, Ramaekers FCS. Tissue speciflc markers in flowcytometry of urological cancers: cy tokeratins in bladder conchoma. Int I Cancer 36: 349-356, 1985.

3. Barlogie B, Drewinko B, Raber MN, Swartzendruber D. Cell knetics in clinical oncolog lla Call Growth. C. Nicolint ted.1. Plenum Press, NY, 773-778, 1982.

4. Stee GG. Crowth kinetics of tumours. Clarendon Press, Oxfors. $197 \pi$.

5. Gratzer HG. Monoclonal antibody to 5-bromo- and 5-Hododeoxyuridine: to nev reagene for deteotion of DNA replication. Science 218: 474-475, 1982.

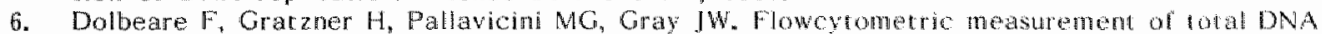
content and incorporated bromodeoxymidine. Proc Natl Acad Sci USA 80: 5573-5577, 1983.

7. Begg AC, MCNally NJ, Schrteve DC, Karcher H. A method to measure the duration of DNA symthesis and the potential doubling time from a single sample. Cynometr: 6: 620-626, 1985.

8. Kinsella TJ, Russo A, Michell JB, Collins JM, Rowland J, Wright [D, Glatstein E. A phase 1 study

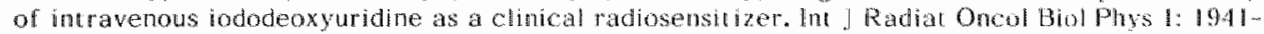
$1946,1985$.

9. Phuphanick $S$, Levin EM, Levin VA. Phase I study of intravenous bromodeoxyuridine used con-

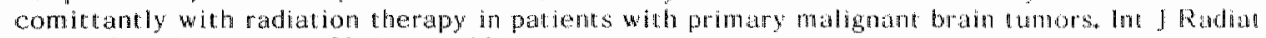
Oncol Biol Pliys 10: 1769-1772, 1984. 
STUDIES WITH ANTI-BROMODEOXYURIDINE ANTIBODIES. I. AN IMPROVED METHOD FOR THE IMMUNOCYTOCHEMICAL DETECTION OF BRDU LABELED NUCLEI USING FLOW CYTOMETRY 


\section{Introduction}

In cell kinetic research, there is a growing interest in the use of immunocytochemistry for the detection of 5-bromodeoxyuridine (BrdU), which S-phase cells have incorporated into their DNA (1-5). Bivariate flow cytometric analysis of BrdU incorporatilon and DNA content allows the calculation of cell kinetic parameters, such as phase distribution, growth fraction and cell cycle traverse time. The most important advantage of this method is that it obviates the need for radioactive DNA precursors and the time consuming methods for their detection (6). The im munocy tochemical method requires in situ denaturation of DNA in order to make the incorporated BrdU accessible to the antibody. This has mainly been accomplished by applying either acid $(7,11)$ or heat $(8)$. Acid denaturation results in a low BrdU detection level (8), which may be insufficient for the detection of slowly cycling cells in solid tumors after in vivo administration of BrdU. In contrast, thermal denaturation of cellular DNA shows higher sensitivity (8), but cannot be applied to cells from bone marrow or peripheral blood, because they are more fragile than other cells and therefore mostly destroyed during thermal denaturation.

Here we describe a new method for the preparation of nuclei for immunocytochemical detection of BrdU, using pepsin digestion of ethanol fixed cells or tissue, followed by acid denaturation of the obtained nuclei. This method is applicable to a variety of cells, including cultured cells, human bone marrow cells and tumor xenografts in nu/nu mice. Because of its high sensitivity, its high cell yield from solid tumors and its low background staining, this method is especially suitable for the analysis of tumor cells labeled in vivo.

\subsection{Materials and Methods}

Several cell lines were used for this study including MCF7 (breast cancer cells), HT-29, Colo-205, 5583 (13) and 2246 (colorectal carcinoma cells). The cell lines 5583 and 2246 are a gift from Dr. C. Verstijnen (Department of Pathology). All cell lines were grown at $37^{\circ} \mathrm{C}$ in Dulbecco"s modified medium supplemented with $10 \%$ Fetal Calf Serum (FCS). Human bone marrow was collected freshly. After lysis of red blood cells in $0.155 \mathrm{M}$ $\mathrm{NH}_{4} \mathrm{Cl}$, white blood cells were cultured at $37^{\circ} \mathrm{C}$ in RPMI 1640 , supplemented with $10 \%$ FCS. 


\section{BrdU Labeling}

Cell lines and human bone marrow cells were pulse labeled in vitro by incubation ( $30 \mathrm{~min}$.$) in BrdU containing medium (10 \mu \mathrm{M}$ final concentration). Cells were harvested by trypsinization, washed in phosphate buffered saline (PBS) and fixed in $70 \%$ ethanol at $4^{\circ} \mathrm{C}$ for at least 30 minutes. In vivo labeling was studied on cell line 2246 grown as xenografts in NMRI nu/nu mice. BrdU $(50 \mathrm{mg} / \mathrm{kg}$ body weight) was administered by i.p. injection. After 1 hour the animals were sacrificed and the xenografts were removed and fixed in $70 \%$ ethanol at $4^{\circ} \mathrm{C}$.

\section{Monoclonal Antibody}

The anti-BrdU monoclonal antibody (clone II B5) was obtained by immunizing Balb/c mice intraperitoneally with BrdU conjugated to bovine serum albumin. Hybridomas were obtained by standard cell fusion techniques and screened in an ELISA using BrdU and thymidine conjugated to ovalbumine as the solid phase antigens. Supernatants of hybridoma cells which reacted with BrdU- but not with thymidine-conjugates were selected by cloning, which was done by limiting dilution. Cloning was repeated until the supernatants of cloned cells were uniformly positive. Antibody affinity was determined by incubating $50 \mu \mathrm{l}$ of culture supernatant with $50 \mathrm{Hl}$ of serial dilutions of [3 $\mathrm{H}]$-BrdU (Amersham, S.A. $40 \mathrm{Ci} / \mathrm{mmol}$ ) in a range of 0.025 to $0.4 \mu \mathrm{Ci}$ in phosphate buffered saline (PBS). After overnight incubation at $4^{\circ} \mathrm{C}$, the bound and free antibody were separated by addition of 100 Hi dextran coated charcoal (DCC) followed by centrifugation. 100 ul of supernatant was used for liquid scintillation counting. The affinity constant was calculated as described by Steward et al. (10) by extrapolation of $\log \mathrm{b} /([\mathrm{At}]$-b) versus $\log [\mathrm{Ag}]$. All tests were performed in duplicate. The specificity of the monoclonal antibody was determined by incubating $50 \mathrm{Hl}$ of a monoclonal antibody dilution which was chosen to bind approximately $50 \%$ of the ligand in a given concentration, with $25 \mu \mathrm{I} 0.025$ $\mu \mathrm{Ci}\left[{ }^{3} \mathrm{H}\right]$-BrdU on $25 \mu /$ of serial competitor dilutions. After overnight incubation at $4^{\circ} \mathrm{C}$ the bound and free antibody were separated as described above. The influence of the addition of competitor or ligand binding was described by plotting the percentage of bound label against the concentration of the competitor, using the logit transformation (11), $\log i t b=\ln b /(100-b)$ where $\mathrm{b}$ is the amount of bound radiolabeled ligand expressed as 
a percentage of that in the zero standard. The specificity of the MOAb was expressed as the ratio of the BrdU concentration, needed to give $50 \%$ competition of radiolabeled ligand binding to the concentration of competitor. All tests were performed in duplicate. Competitors used were bromodeoxyuridine (Serva, 15240), bromouridine (Sigma, B9752), deoxythymidine (Serva, 18600) and adenosin (Serva, 10770).

\section{Cytochemistry}

Ethanol fixed cells were pelleted and digested with pepsin (Boehringer Mannheim GmbH, 108057, $0.4 \mathrm{mg} / \mathrm{ml}$ in $0.1 \mathrm{~N} \mathrm{HCl}$ ) for 30 minutes at room temperature (RT). In some experiments the pepsin concentration was varied. The ethanol fixed solid tissue was digested with pepsin $(0.4 \mathrm{mg} / \mathrm{m} \Perp$ in $0.1 \mathrm{~N} \mathrm{HCl})$ for 1 hour at RT under constant agitation. The reaction mixture was sieved through a $50 \mu \mathrm{m}$ nylon mesh to remove tissue fragments. The enzymatic treatment was terminated by washing the cell suspension twice in PBT buffer (PBS, BSA $1 \mathrm{mg} / \mathrm{ml}$, Tween 20, $0.05 \% \mathrm{v} / \mathrm{v}, \mathrm{pH} 7.4$ ).

In order to make antibody binding sites accessible approximately $2.10^{6}$ ethanol fixed cells or nuclei were suspended in $2 \mathrm{~N}$ $\mathrm{HCl}$ and incubated for 30 minutes at $37^{\circ} \mathrm{C}$. After washing in borax buffer $(0.1 \mathrm{M}$ sodium tetraborate, $\mathrm{pH} 8.5)$ and PBT, cells were resuspended in $100 \mu \mathrm{l}$ of anti-BrdU antibody containing culture supernatant. After 1 hour at RT, PBT buffer was added, the cells or nuclei were sedimented, washed once and resuspended in $100 \mu 1$ rabbit anti-mouse $\operatorname{IgG-FITC}$ (Dako F 3\$3, 1:50 dilution in PBT) for 1 hour at RT. The cells or nuclei were washed twice in PBT and finally resuspended in $50 \mu 1$ PBS containing $10 \mu \mathrm{g} / \mathrm{ml}$ propidium iodide (Calbiochem 537059). The samples were ready for flow cytometric analysis after 15 minutes. Before analysis the cells or nuclei were syringed through a 23 gauge needle.

In one experiment ethanol fixed cells were stained according to the thermal denaturation procedure described by Dolbeare et al. (8). Briefly, ethanol fixed cells were first incubated with RNAse (Serva, $1 \mathrm{mg} / \mathrm{ml}$ ) for 20 minutes at $37^{\circ} \mathrm{C}$, sedimented and resuspended in cold $0.1 \mathrm{~N} \mathrm{HCl}$ for 10 minutes. The cells were then incubated for 30 minutes at $80^{\circ} \mathrm{C}$ in $50 \%$ formamide $(v / v)$ in PBS. Tubes were cooled in ice water and after 5 minutes PBT was added and each tube was mixed rigorously. Cells were then stained for BrdU and DNA content as described above. 


\section{Flow Cytometry}

Double stained cells were analysed on a FACS IV cell sorter (Becton \& Dickinson, Sunnyvale, CA) equiped with a 4W Argon Ion Laser (Spectra Physics, model 164-05) operating at 400 mWatt output at $488 \mathrm{~nm}$. A $520 \mathrm{lp}$ filter was used to block scattered light. Log green fluorescence was measured through a 540 $\mathrm{sp}$ filter and recorded as a measure of the amount of bound anti-BrdU antibody. Red fluorescence was measured through a 620 Ip filter and was recorded as a measure of the amount of bound PI. The relative anti BrdU fluorescence intensity (RFI) was calculated as the ratio of the modal green fluorescence of cells in S-phase to the modal green fluorescence of cells in $G_{1}$ phase of the cell cycle, using RFI $=10 \exp (0.0198 \Delta), 0.0198$ being the factor for the conversion of $\log$ to linear fluorescence distributions and $\Delta$ being the difference in modal log green fluorescence channel of cells in $S-$ and $G_{1}$-phase of the cell cycle.

\section{$\overline{7.2}$ Results}

The binding characteristics of the monoclonal antibody !clone II B5) were determined in a radioim munoassay using $\left[{ }^{3} \mathrm{H}\right]$-BrdU as a ligand. The affinity constant was found to be $3.1 \times 10^{7} \mathrm{~L} / \mathrm{mol}$, comparable to $4.0 \times 10^{7} \mathrm{~L} / \mathrm{mol}$ for the commercially available clone B44 (Becton \& Dickinson). As shown in table I clone II B5 was highly specific for BrdU or bromouridine (BrU) and hardly reacted with the structurally related nucleotides thymidine or adenosin.

bromodeoxyuridine (BrdU) 1

bromouridine

0.3

deoxythymidine

0.0002

5 -fluorodeaxyuridine

0.0006

adenosine

0.00002 
In a bivariate BrdU/DNA analysis on ethanol fixed cells, we observed specific S-phase cell labeling after acid denaturation (figure $1 \mathrm{~A}$ ), while in cells which had not incorporated BrdU no immunoreactivity was observed (data not shown). Surprisingly, in attempting to reduce background staining by isolating nuclei after pepsin treatment, we observed an increase in the specific immunofluorescence signal. Figure $1 \mathrm{~B}$ shows a bivariate BrdU/ DNA analysis recorded at equal photomultiplier settings as compared to figure IA on nuclei, isolated by pepsin treatment of ethanol fixed cells. The green (anti-BrdU) fluorescence of $\mathrm{G}_{1}$ and $\mathrm{G}_{2} / \mathrm{M}$ cells was shifted towards lower, whereas the green fluorescence of labeled S-phase cells was shifted towards higher channel numbers. Simultaneously, there was a shift towards lower channel numbers in the red fluorescence (DNA content).

To further investigate the effect of pepsin pretreatment on antiBrdU immunofluorescence intensity of $S$-phase cells, various concentrations of the enzyme were tested. As indicated in figure 2 the fluorescence intensity progressively increased with increasing pepsin concentrations, whereas the resolution of the DNA histograms was not seriously affected. For further experiments a pepsin concentration of $0.4 \mathrm{mg} / \mathrm{ml}$ was chosen.

In a second series of experiments the applicability of this method to various cell types was investigated. Furthermore, heat and acid denaturation protocols for whole cells were compared.

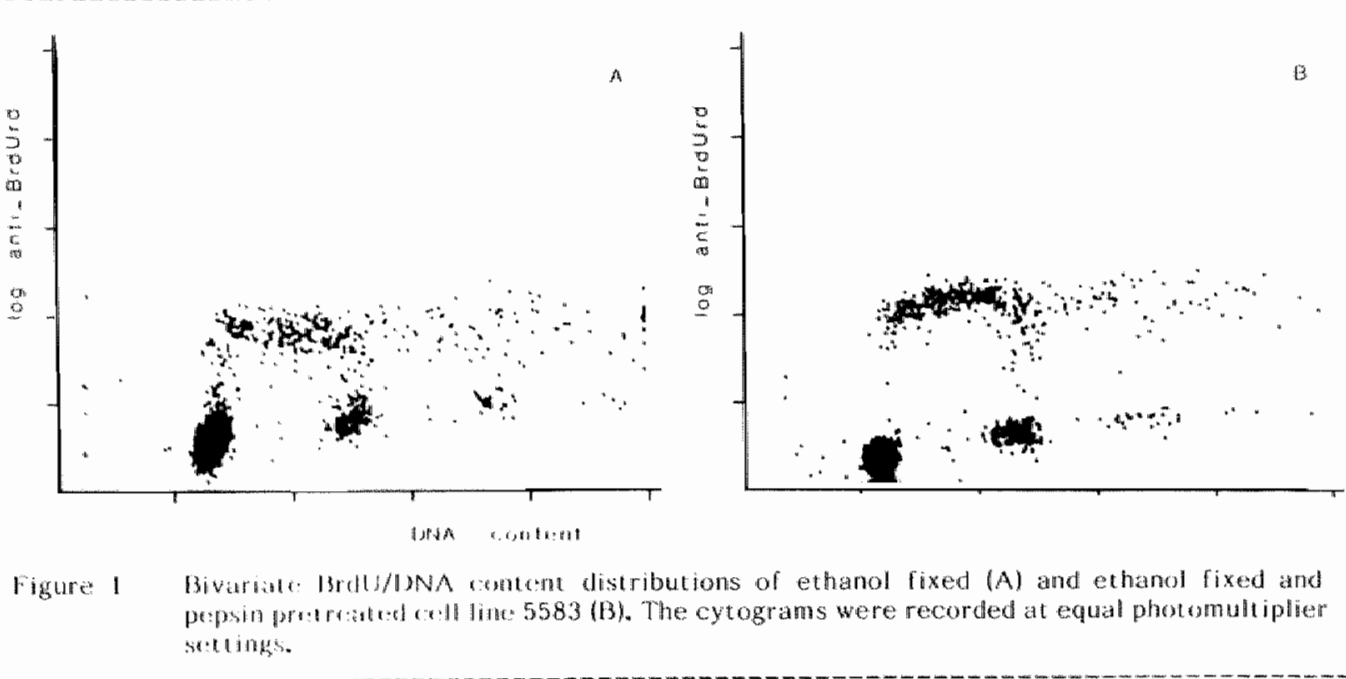


Table 2 summarizes the results. BrdU staining of human bone marrow cells after heat denaturation appeared to be impossible due to loss of cells. The RFI values were the highest for heat denatured cells, for pepsin digested and acid denatured nuclei only marginally lower but for acid denatured cells clearly inferior. Analysis of intact bone marrow cells was often hampered by nonspecific staining of non BrdU labeled $G_{1}$ cells presumably due to $\mathrm{Fc}$-binding. The preparation of stripped nuclei appeared to overcome this problem (data not shown).

When applied to ethanol fixed tissue fragments, pepsin treatment was able to digest the tissue almost completely after 1 hour at RT. The obtained nuclei from tumor xenografts showed specific S-phase labeling (figure 3).

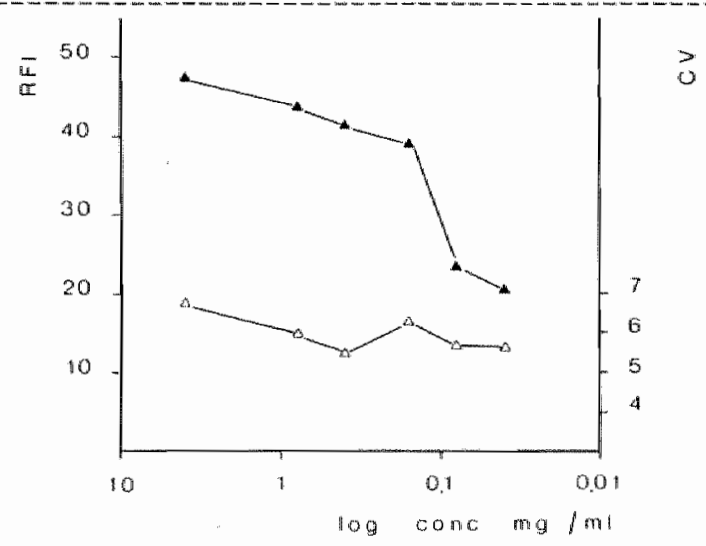

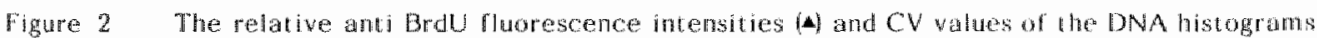
(4) of cell line 5583 at various pepsin concentrations.

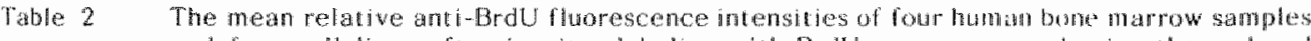

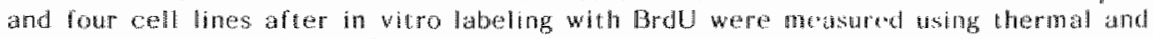
actd denaturation either with or whow pepsin pretreatment. All experingents were per.. romed ira duplicate.

Relative Brdu fluorescence intensity.

Acid denaturation Heat denaturation standard + pepsin

$\begin{array}{lccc}\text { Bone marrow } & 7.0 & 20.0 & \text { n.p. } \\ \text { (in vitro) } & 12.0 & 66.0 & 98.8 \\ \text { Cell lines } & \end{array}$

m.p. = not possible 


\subsection{Discussion}

Most procedures for the identification of BrdU labeled cells are based on the use of MoAbs that recognize BrdU in single-stranded DNA. In order to expose the binding sites for the antibodies, in situ denaturation of cellular DNA is needed prior to the immune reaction. In the original paper on immunocytochemical detection of S-phase cells by Gratzner et al. (12), acid denaturation of DNA was used. Although applicable to a variety of cell types, this method is hampered by a relatively small difference in the specific immunofluorescence intensity in S-phase cells in comparison to the background fluorescence of $G_{1}$ phase cells (8). An alternative technique, based on thermal denaturation of DNA, appeared to yield more intensive immunostaining (8). However, thermal denaturation in the presence of $50 \%$ formamide resulted in loss of fragile cells, as present in bone marrow and peripheral blood. Recently, a modification of this technique was described, consisting of heat denaturation at low ionic strength which improves its performance on fragile cells (9).

In the present paper, we describe a method for the immunocytochemical detection of BrdU labeled nuclei, which were obtained by pepsin treatment of ethanol fixed cells or tissue. We observed a reduction of background staining and an increased specific fluorescence intensity. Pepsin treatment probably leads to more extensive denaturation of DNA, since the peak $G_{1}$ red fluorescence (for native DNA) was also shifted towards lower intensity.

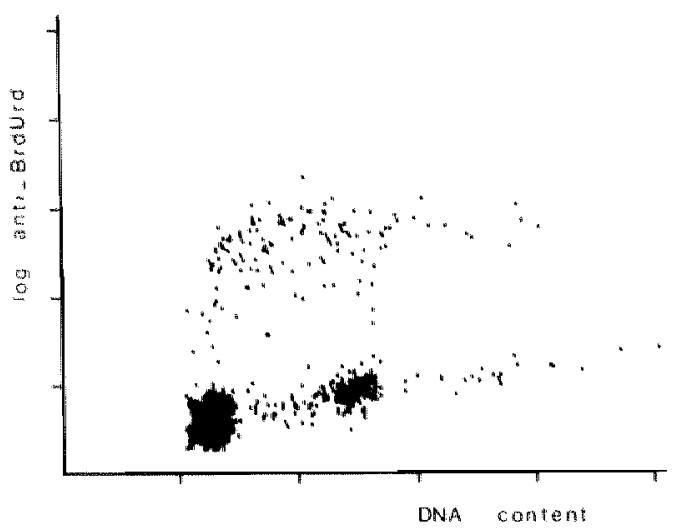

H. Hare: 3 Bivariate BrdU/DNA content distributions of ethanol fixed tissue fragments al cell line 2246, grown as xenograft in NMRl nu/nu mice, after digestion with pepsin. 
Overall, this combination resulted in a significantly better sensitivity with a low cell loss due to enzyme digestion of approximately $30 \%$, and an efficiency in producing bare nuclei of greater than $90 \%$ as determined both microscopically and flow cytometrically using forward angle light scatter.

The method described in this paper performed well on all cell types tested and resulted in a sensitivity which was equal to that obtained with the thermal denaturation protocol. The pepsin digestion step prior to DNA denaturation and BrdU staining appears to serve a dual purpose. Firstly, the anti-BrdU immunofluorescence intensity is increased, and secondly, by removing the cellular membrane and cytoplasm, the binding of antisera to cell surface $\mathrm{Fc}$ receptors is avoided $(7,14)$. The isolated nuclei, however, did show a tendency to aggregate, which could be partly overcome by syringing the samples. Our method does not allow the simultaneous measurement of cell surface antigens and BrdU incorporation (15). However, cells can first be sorted using antibodies against cell surface antigens and subsequently be digested with pepsin and stained for the presence of BrdU. Because of the pepsin digestion step background staining should not be a significant problem. With this sequence kinetic studies of phenotypically defined cells are possible without complex combinations of fluorochromes and dual laser excitation. Our method may be particularly relevant for cell kinetic studies in human solid tumors, after in vivo labeling. Recently, Begg et al. (16) described a mathematical approach using data from one sample, making such studies more feasible; a major problem, however, remains the low recovery of single cells from unfixed tissue. We have shown that BrdU can be detected in nuclei isolated from ethanol fixed tissue fragments, which we have found to be very efficient, allowing analysis on tissue fragment as small as $5 \mathrm{~mm}^{3}$. This is especially important when only a limited amount of tissue is available. Sparing use of tissue specimens also allows histological control of the tissue specimen. From such parallel flow cytometric and immunohistochemical estimations of BrdU labeled cells, we found that there was no evidence of preferentially gain or loss of S-phase nuclei after enzym digestion since the labeling index did not differ significantly between the two methods. However, as illustrated in figure 3, some cells with S-phase DNA content were not immunofluorescently stained. As we have shown elsewhere (17) by simultaneous immunohistochemistry and autoradiography, the 
specificity of the immunocytochemical technique is greater then $99 \%$. Therefore, the most probable explanation for the phenomenon of unlabeled S-phase cells is that these cells did not incorporate BrdU rather than a staining artifact. With this technique cell kinetic studies of human solid tumors after an in vivo labeling procedure can be performed which may provide important information related to the optimal scheduling of chemotherapeutic or radiotherapeutic treatment. 


\section{References}

1. Pallawicin MG, Summers L. J, Dobeare FD, Gray JW. Cylokinetic propertes of a synchronous and cytosine-arabinoside perturbed murine tumor measured by simultaneous bromodeonuridine/DNA analysis. Cytometry 6: 602-610, 1985,

2. Hoshino T, Nagashima T, Murovic J, Levin EM, Levin WA, Rupp SM. Cell thetic studies of in silu human brain tumors with bromodeoxyuridine. Cytometry 6:627-632, 1985.

3. Raza A, llar K, Preisler HD. Double labeling and in virro versus in vivo incorporation of bromodeoxyuridine in patients with acute nonlymphocytic leukenia. Cytomeny $6: 633-640,1985$.

4. Morsijn $G$, Msu SM, Kinsella T, Gratzner H, Russo A, Mitchell JB. Bromodeoxyuridine in lumors. and chromosomes detected with monoclonal andoody. J Clin Invest 72: 1844-1850, 1983.

5. Morstijn G, Kinsella T, Hsu SM, Russo A, Gratzer H, Mitchell JB. Identilication ol brathendeoxy. uridine in malignant and normal celss following therapy: relationship to complications. Int I Radiarion Oncology Biol Phys 10 : 144t-1445, 1984.

6. Yamagisawa $M$, Dolbeare F "Todorohi T, Gray JW. Cell cycle analysis using numeral stimulation of bivariate DNA/Bromodeoxyuridine distributions. Cytometry $6: 550-562,1985$.

7. Dobeare F, Gatzer H, Pallawich M. Gray JW. Flowcytometric measuremen of Lotal DNA onlent and incorporated bromodeoxyuridine. Proc Nall Acad Sci US 80: 5573-5577. 1983.

8. Dolbeare F, Beisker W, Pallavicini MG, Vanderlan M, Gray IW, Cytochemistry fon Bromodeaxyuridine/DNA analysis: stoichiometry and sensitivily. Cytometry 6: 52 I-530, 1985.

9. Moran R, Darzynkiewicz 2, Stabno-Coico L, Melamed MF. Detection of 5-bromodeoxyuridine (Brdurd) incorporation by monoclonal antibodies: role of the WNA denaturation step. I Histochom Cytochem 33: 821-827, 1985 .

10. Steward MW, Petry RE. The use of ammonium sulphate globulin precipitation for determination wo affinity of antiprotein antibodies in mouse serum. Immunology 22: 747-756, 1972.

II Charef T. An introdaction to radioimmunossay and related techniques. In: Laboratory Tethnigues in Biochemistry and Molecular Bology. Work TS and Work E leds. H. Elsevier Biomedical, Ansterdam. 1982.

12. Gratzner H. Monoclonal antibody against 5-bromo- and 5-iododeoxyuridine: a new reagent for detection of DNA replication. Science 218: 474-475, 1982.

13. Verstijnen CPHJ, Arends JW, Moerkerk PTM, Getaedts JPR, Uitendan PM, Bosman FT. Heterogeneous cell lines derived from one colonic carcinoma: establishment and chanacterization. Subminted.

14. Raza A, Preister HD, Mayers CL. Blankert R. Rapid entmeration of S-phase cells by muans of monoclonal antibodies. New Engl I Med 310: 991, 1984.

15. Houck DW, Loken MR. Simultaneous analysis of cell surlace antigens, bromodeoxyridine incorporation and DWA content. Cybomedy 6: $531-538$, 1985.

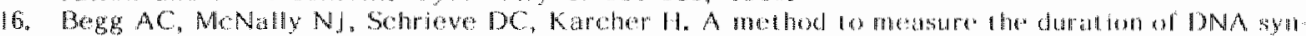

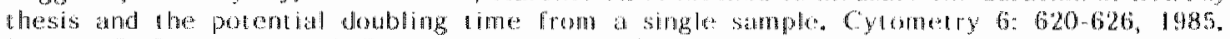

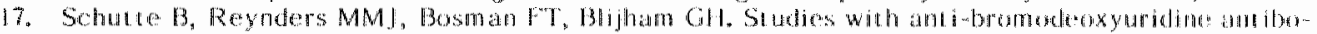

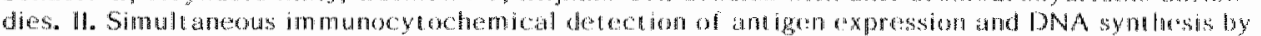
in wivo labeling of mouse incestinal mucosid. J flishochem Cyouchem 35: $371-374.1987$. 

URIDINE IMMUNOHISTOCHEMISTRY 


\section{Introduction}

The immunocytochemical detection of bromodeoxyuridine (BrdU) incorporated into DNA has become a powerfull tool for the study of the cytokinetics of normal and neoplastic cells (1-3). Detection of incorporated BrdU is less laborious and time consuming than autoradiography of incorporated tritiated thymidine and obviates the need for radioactive DNA precursors. One essential prerequisite for effective BrdU immunocytochemistry, however, is accessibility of antibody binding sites, which may be achieved through acid denaturation of DNA.

In this report, we describe the influence of various fixatives on monoclonal anti-BrdU antibody binding of BrdU substituted DNA in tissue sections of routinely processed mouse small intestine after in vivo administration of BrdU. In addition, the influence of pepsin digestion of tissue sections, prior to acid denaturation, on the BrdU immunoreactivity was investigated.

\subsection{Materials and Methods}

\section{Animals}

Balb/c mice weighing $30-40 \mathrm{~g}$ and fed ad libitum with a standard laboratory diet were used.

\section{BrdU Labeling}

Mice received $\mathrm{BrdU} 50 \mathrm{mg} / \mathrm{kg}$ body weight in a single bolus injection administered intraperitoneally. After 1 hour the animals were sacrificed and the small intestines were removed.

\section{Tissue Processing}

Samples of the small intestines were fixed in $10 \%$ neutral buffered formalin, bouin's fluid (4), carnoy (4), ethanol (70\%), $2.5 \%$ glutaraldehyde in $0.1 \mathrm{M}$ phosphate buffer (4), periodate-lysine paraformaldehyde (PLP) (5) or picric acid-paraformaldehyde (6) overnight at roomtemperature (RT). The tissues were paraffinembedded according to routine histological procedures. Part of the formalin-fixed tissue was embedded in Spurr's resin (7). 4 $\mu \mathrm{m}$ tissue sections were cut and mounted on gelatin-coated slides and incubated overnight at $37^{\circ} \mathrm{C}$ to improve adhesion of the sections to the slides. For plastic-embedded material $1 \mathrm{um}$ sections were used. In addition, frozen sections of fresh material were cut at $4 \mu \mathrm{m}$ and fixed for 20 minutes at $-20^{\circ} \mathrm{C}$ in acetone. 


\section{Immunohistochemistry}

An indirect enzyme labeled antibody technique with peroxidase conjugated second step reagents was used. Tissue sections were cleared of paraffin with two changes of xylene and rehydrated in a graded series of ethanol. Tissue sections, embedded in Spurr's resin were treated with $30 \%$ saturated $\mathrm{NaOH}$ in absolute ethanol for $10 \mathrm{~min}$. at RT. Endogenous peroxidase was blocked by immersing the sections in $0.3 \% \mathrm{H}_{2} \mathrm{O}_{2}$ in methanol for 10 minutes. In some cases tissue sections were digested with varying concentrations of pepsin (Boehringer), ranging from 0 (control) or 0.04 to $4 \mathrm{mg} / \mathrm{ml}$ in $0.1 \mathrm{~N} \mathrm{HCl}$, followed by rinsing twice in PBS (phosphate buffered saline, $\mathrm{pH}$ 7.4). After incubation in 2 $\mathrm{N} \mathrm{HCl}$ for $30 \mathrm{~min}$. at $37^{\circ} \mathrm{C}$ the slides were washed twice in 0.1 $\mathrm{M}$ borax buffer $\mathrm{pH}$ 8.5, once in PBS and incubated with monoclonal anti-BrdU antibody (8) containing culture supernatant for 1 hour at $37^{\circ} \mathrm{C}$, followed by washing twice in PBS containing BSA $(1 \mathrm{mg} / \mathrm{ml})$. The slides were finally incubated with peroxidase conjugated rabbit anti-mouse Ig (Dako, 1:200 diluted in PBS/BSA for 1 hour at RT. After washing twice in PBS/BSA the antibody binding sites were visualized by submersing the slides in $0.04 \%$ diaminobenzidine in $0.05 \mathrm{M}$ Tris $\mathrm{pH} 7.6$ to which $\mathrm{H}_{2} \mathrm{O}_{2}(0.01 \%)$ had been added just before use. The sections were finally counterstained with haematoxylin and mounted with entellan. In control slides the monoclonal anti-BrdU antibody was substituted by an indifferent monoclonal antibody of the same immunoglobulin subclass (Leu-2b, Becton \& Dickinson). The slides were scored for immunoreactivity and morphology by two independent observers.

\section{$\overline{8} . \overline{2}$ Results}

Table 1 shows the immunoreactivity of BrdU in tissue sections after various fixation protocols. Included in this table are frozen sections and sections of formalin-fixed plastic-embedded tissues. Except for Bouin's fluid, picric acid-paraformaldehyde, PLP and glutaraldehyde-fixed tissues, all sections showed a specific nuclear labeling of crypt cells. For most fixatives, tissue sections showed a remarkable increase in staining intensity after digestion with pepsin prior to acid denaturation. Moreover, with fixatives showing no immunoreactivity of BroU labeled crypt cells, positive staining was obtained after pepsin treatment (figure 1). Invariably, the intensity of staining increased with 

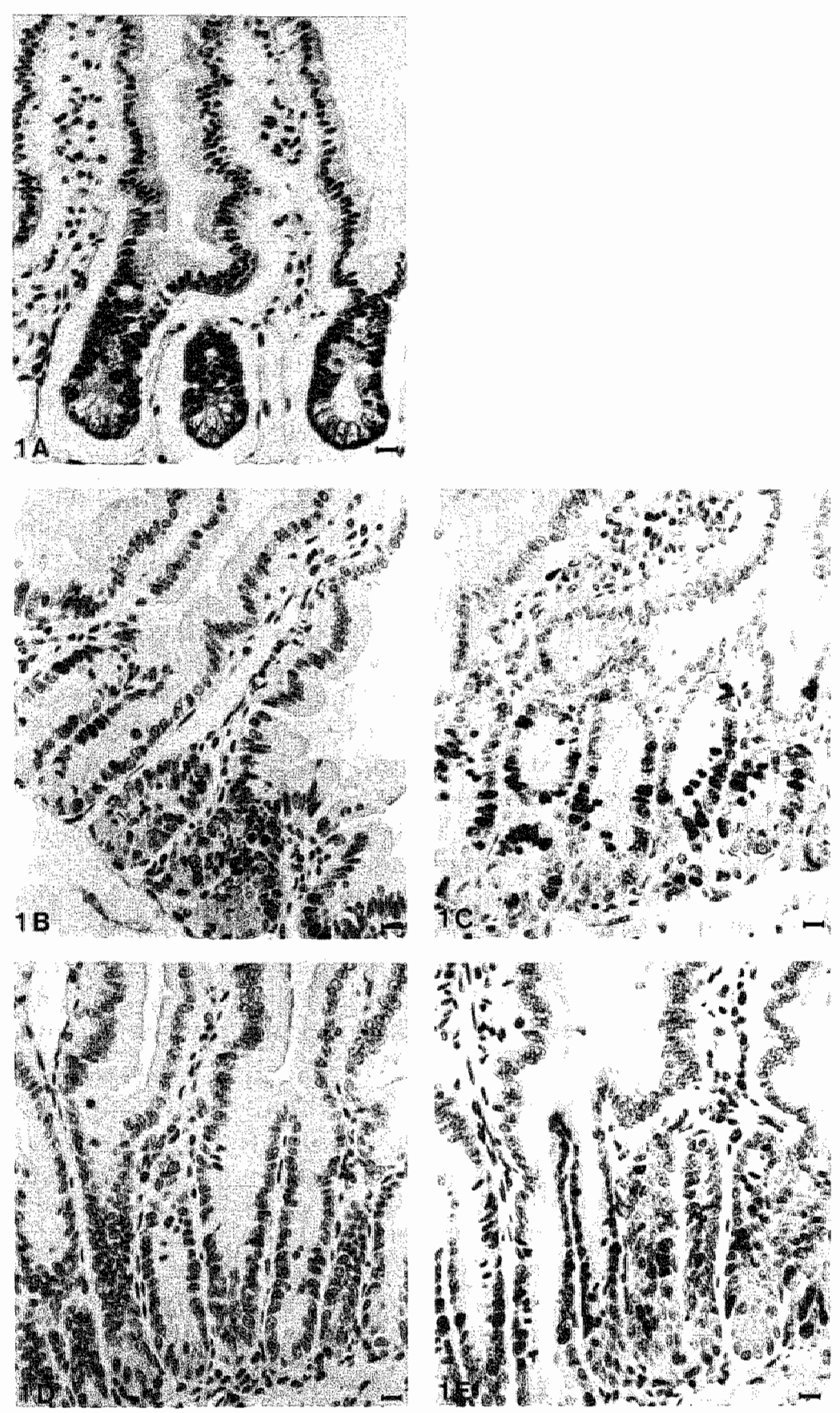

Figure 1 Anti-BrdU immunoreactivity in mouse small intestine after in viwo labeling with Brdu. Tissues were fixed in $70 \%$ ethanol $(A), 10 \%$ netstral bufered formatin (B), including pepsin digestion at a concent ration of $0.4 \mathrm{mg} / \mathrm{m} /(\mathrm{C})$ and $2.5 \%$ buf fered glutaraldehyde (D) incluw. ding pepsin digestion at a concentration of $4 \mathrm{mg} / \mathrm{m}$ ! (E). The bar represents $16 \mathrm{um}$. 
increasing pepsin concentrations over the range studied. However, morphology was seriously affected at high pepsin concentrations in a fixative dependent way. Table 2 shows the optimal concentrations of pepsin at which maximal immunoreactivity was combined with acceptable morphology.

Table 1 The effect of various fixatiwes on anti-Brdu immunoreactivity mouse snall intestine using the standard acid denaturation protocol. Crypt cell labeling was scored as posive $(+)$, weak (H/n) on negative (-).

Fixative Immunoreactivity

formalin

ethanol

bouin

carnoy

$+1-$

picric acid paraformaldehyde

PLP

glutaraldehyde

$+$

-

$+1-$

frozen sections

formalin

(plastic embedding)

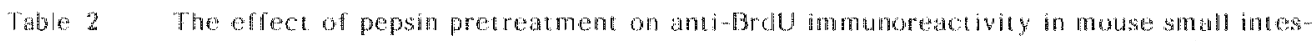
tine. The optimal pepsin concentration for the deferent fixatives is given for whith maximal immunomeactivity is ombined wh acceptable morpholgy.

Fixative Pepsin concentration $(\mathrm{mg} / \mathrm{ml})$

\begin{tabular}{ll}
\hline formalin & 0.4 \\
ethanol & 0 \\
bouin & 0.04 \\
carnoy & 0 \\
picric acid paraformaldehyde & 0.4 \\
PLP & 0.04 \\
glutaraldehyde & 4 \\
frozen sections & \\
formalin & 0 \\
(plastic embedding) & 4
\end{tabular}




\section{$\overline{8.3}$ Discussion}

Fixation of cell or tissue specimens is a crucial step in immunocytochemistry. Invariably, the balance between optimal preservation of immunoreactivity and optimal morphology has to be empirically established.

In the present report, we evaluated the influence of the fixation protocol on BrdU immunoreactivity in mouse small intestinal mucosa after in vivo labeling. Tissues fixed in denaturing fixatives such as ethanol or Carnoy's fluid invariably showed immunoreactivity, while cross-linking agents e.g. formalin and glutaraldehyde demonstrated weak or no reaction at all. By pretreatment of tissue sections with pepsin, the staining intensity of crypt cells was increased after formalin fixation. Furthermore, in glutaraldehyde-fixed tissue BrdU incorporation could be detected after digestion with pepsin in high concentration, without seriously affecting morphology. The effect of pepsin digestion can be explained by a facilitation of DNA denaturation due to digestion of chromatin-associated proteins. The optimal conditions of pepsin digestion of tissue sections fixed in different fixatives will be determined by (i) the effect of pepsin cligestion on tissue morphology, (ii) the possible cross-linking effect of the fixatives on DNA. As a consequence, cross-linking agents such as formalin and glutaraldehyde require higher pepsin concentrations for an optimal effect than denaturing fixatives e.g. ethanol or Carnoy's fluid. The increase in immunoreactivity was due to pepsin digestion and not to the additional incubation in $0.1 \mathrm{~N} \mathrm{HCl}$, since control incubation did not show any effect. Recently, alternative techniques to obtain single-stranded DNA have been developed which include thermal denaturation or nuclease digestion $(9,10)$. Since, depending on the fixative used, the DNA melting curves or the efficiency of nuclease digestion will vary; results obtained with these denaturation protocols will also be influenced by the applied fixatives.

In conclusion, the present report describes the effect of tissue fixation on immunocytochemical detection of BrdU. Pepsin digestion prior to acid denaturation of cellular DNA improves staining efficiency, and allows the detection of BrdU-substituted DNA under all tested fixation conditions. However, the optimal pepsin concentration varies for the different fixatives in relation to the efficiency of DNA denaturation after fixation and the resulting tissue morphology. 


\section{References}

1. Dolbeare FA, Gratzer HC, Pallavicini MG, Gray JW. Flow cytometric measurement of total DNA content and incorporated bromodeoxyuridine. Proc Nat Acad Sci USA 80: 5573-5577, 1983.

2. Hoshino T, Nagashima T, Muravic J, Levin EM, Levin VA, Rupp SM. Cell kinetic studies of in stu humar brain tumors with bromodeoxyuridine. Cycometry $6: 627-632,1985$.

3. Raza A, Ucar K, Preisler HD. Double labeling and in vitro versus in vilo incomporat hon of bromodeoxyuridine in patients with acute non lymphocytic leukemia. Cytonnetry 6: 633-640, 1985.

4. Bancroft JD. Histochemical techniques, 2nd Ed. London and Boston: Butterworks, 1975.

5. Mclean IW, Nakane PK. Periodate-Lysine-paraformaldehyde fixative. A new fixative for immumoelectromicroscopy. I Histochem Cytochem 22: 1077, 1974.

6. Stefanini M, de Marbino L, Zamboni ll.. Fixation of ejaculated sperm atozon for electronmicroscopy. Nature $216: 173,1967$.

7. Spurr AR. A low-viscosity epoxy resin embedding medium for electronmicrascopy. I Ultrastruct Res 26: $31-43,1969$.

8. Schutte B, Reynders MMJ, Bosman IFT, Bbijham GH. Studtes with arti-bromodeoxyuridine antibodies. II. Simultaneous detection of antigen expression and DNA synthesis by in viwo labeling of mouse intestinal mucosa. J Histochem Cycochem 35: $371-374,1987$.

9. Dolbeare F, Beisher W, Pallavicini MG, Vanderlan W, Gray JW, Cytochenistry for bromodeoxy uridine/DNA analysis: stotchiometry and sensitivity. Cytometry 6: 521-530, 1985.

10. Gonchoroff NJ, Greipp PR, Kyle RA, Katzmann JA. A monoclonal artibody reactive with 5 bromondeoxyuridine that does not reguire IDNA denaturation. Cytometry 6: 506-512, 1985. 
STUDIES WITH ANTI-BROMODEOXYURIDINE ANTIBODIES. II. SIMULTANEOUS IMMUNOCYTOCHEMICAL DETECTION OF ANTIGEN EXPRESSION AND DNA SYNTHESIS BY IN VIVO LABELING OF MOUSE INTESTINAL MUCOSA 


\section{Introduction}

Flow cytometric (FCM) analysis of cell DNA content is widely used for the estimation of cell cycle phase distributions $(1,2$, $3)$. However, this analysis does not provide cytodynamic information such as cycle traverse rates and phase transit times. These parameters can be obtained using autoradiographic techniques, in particular, by determining the fraction of labeled mitosis (4, 5, 6). By autoradiographic identification of labeled cells during various intervals after labeling, their transition through the subsequent mitotic divisions can be followed, and phase and cycle transit times can be calculated.

Recently, non-autoradiographic methods for distinguishing DNA synthesizing cells have been developed. These use monoclonal antibodies to measure the incorporation of bromodeoxyuridine (BrdU) into cellular DNA (7-14). By use of immunocytochemical detection methods, the number and localization of cells containing BrdU substituted DNA can be determined. Combination of this technique in double labeling experiments with immunocytochemical staining of cellular antigens does allow the study of the kinetic behaviour of specific subpopulations of cells. In this report, we describe such a method for simultaneous assessment of BrdU incorporation and specific antigen immunoreactivity on both paraffin-embedded and frozen tissue sections. As a model system, in vivo labeling of mouse intestinal mucosa was chosen. This technique allows the study of (i) the cytokinetic characteristics of phenotypically defined cells in heterogeneous populations and (ii) antigen expression in relation to the cell cycle progression.

\subsection{Materials and Methods}

\section{Animals}

Throughout the experiments, Balb/c mice, weighing 30-40 $\mathrm{g}$ and fed ad libitum with a standard laboratory diet, were used.

\section{Antisera}

Rabbit anti-serotonin antiserum was prepared by immunizing Flemish giant rabbits with serotonin-BSA conjugates prepared according to Verhofstad et al (15). The anti-bromodeoxyuridine monoclonal antibody (clone II B5) was obtained after immunization of Balb/c mice with BrdU conjugated to Bovine Serum Albumine (13). Spleen cells of immunized mice were fused with murine SP2/0 myeloma cells in a $2: 1$ ratio using polyelthylene- 
glycol (PEG 1500, BDH, $0.5 \mathrm{~g} / \mathrm{ml}$ ). Fused cells were selected in hypoxanthine, aminopterin and thymidine containing Dulbecco"s modified medium. Hybridomas were screened in an ELISA using BrdU and thymidine conjugated to ovalbumin as the solid phase antigens. Supernatants of wells which reacted with the BrdU but not with the thymidine-conjugate were selected for cloning, which was done by limiting dilution. Cloning was repeated until supernatants of cloned cells were uniformly positive. The immunoglobulin subclass was determined by incubation with antimouse immunoglobulin subclass specific antisera (Nordic) in a spot test using nitrocellulose paper. The anti-BrdU monoclonal antibody was of the $\lg G_{1}$ subclass. The binding characteristics of the monoclonal antibody were determined in a radioimmunoassay using $\left[{ }^{3} \mathrm{H}\right]$-BrdU as a ligand. The affinity constant was $3.1 \times 10^{7}$ $1 /$ mol. The specificity was tested in the same assay using structurally related nucleosides as competitors. The monoclonal antibody showed a 5000 and greater than 50.000 fold higher affinity for bromodeoxyuridine as compared to thymidine and adenosine, respectively.

As secondary step reagents, peroxidase-conjugated rabbit antimouse $\lg$ (Dako, Pl61) and peroxidase-conjugated goat anti-rabbit Ig (Nordic, 14-877) were used.

Balb/c mice were injected intraperitoneally with 50,5 and 0.5 $\mathrm{mg} / \mathrm{kg}$ BrdU respectively. After 1 hour the animals were sacrificed and the liver, kidneys and small intestine were removed. For comparative immunocytochemistry and autoradiography $\mathrm{Balb} / \mathrm{C}$ mice were injected with $25 \mu \mathrm{Ci}$ of $\left[{ }^{3} \mathrm{H}\right]$-BrdU (Amersham, SA $40 \mathrm{Ci} / \mathrm{mmol}$ ) supplemented with unlabeled BrdU to give a final dose of 50,5 and $0.5 \mathrm{mg} / \mathrm{kg}$ respectively.

\section{Tissue Preparation}

Tissues were fixed in 10\% neutral buffered formalin and paraffin-embedded according to routine histological procedures. Sections $(4 \mu \mathrm{m})$ were mounted on slides previously coated with gelatin. The slides were dried overnight at $37^{\circ} \mathrm{C}$ to improve adhesion of the sections to the slides. Unfixed fresh tissue specimens were frozen in liquid nitrogen and stored at $-80^{\circ} \mathrm{C}$. Four $\mu \mathrm{m}$ cryostat sections were cut and mounted on gelatin-coated slides. The sections were fixed $\left(20 \mathrm{~min}\right.$. at $\left.-20^{\circ} \mathrm{C}\right)$ in absolute acetone prior to immunocytochemistry. 


\section{Immunocytochemistry}

An indirect labeling technique with peroxidase conjugated secon step reagents was used. As chromogen in the peroxidase reactiol for the visualization of the first antigen 3,3'-diaminobenzidine tetrahydrochloride (DAB) (Fluka $A G, 32750$ ) was used, and fo the second antigen DAB supplemented with $\mathrm{CONO}_{3}(1 \% \mathrm{w} / \mathrm{v})$ wa applied (16). Tissue sections were cleared of paraffin with tw changes of xylene and rehydrated in a graded series of ethano to water. Endogenous peroxidase was blocked by immersing th sections in $0.3 \% \mathrm{H}_{2} \mathrm{O}_{2}$ in methanol for 1.0 minutes, with subse quent washing in water. After rinsing in PBS, excess liqui around the sections was removed by blotting. The slides wer incubated with rabbit anti-serotonin antiserum for 1 hour a room temperature (RT). After washing $(3 x)$ in PBS, the secon dary antibody (goat anti-rabbit $\mathrm{Ig}$ ) was applied for 1 hour a RT. The sections were finally washed with PBS and submerged $i$ $0.04 \% 3,5^{\prime}$-diaminobenzidine $(10 \mathrm{~min}$.) in $0.05 \mathrm{M}$ Tris, $\mathrm{pH} 7.6 \mathrm{t}$ which $\mathrm{H}_{2} \mathrm{O}_{2}(0.01 \%)$ had been added just before use. For im munocytochemical detection of BrdU incorporation, the sectior were subsequently incubated in $2 \mathrm{~N} \mathrm{HCl}$ for 30 minutes at $37^{\circ} \mathrm{C}$ After treatment with $0.1 \mathrm{M}$ sodiumtetraborate (UCB, 8529), pl 8.5, the slides were washed in PBS. Incubation conditions for th monoclonal anti-BrdU antibody and its secondary reagent ( $R$ anti-mouse (g-HRP) were similar to those for the first antiger the only difference being the incubation with the monocloni anti-BrdU antibody at $37^{\circ} \mathrm{C}$. Im munoreactive sites were detect by submerging the slides in $0.04 \% \mathrm{DAB}$, supplemented wit $\mathrm{CoNO}_{3}(0.02 \%)$, in $0.05 \mathrm{M}$ Tris $\mathrm{pH} 7.6$, to which $\mathrm{H}_{2} \mathrm{O}_{2}(0.01 \%$ had been added just before use. Finally, the sections were cour terstained with nuclear fast red and mounted with aquamount. I control slides, anti-serotonin and anti-BrdU antiserum were sut stituted by respectively normal rabbit serum and Leu-2a (ant human T suppressor cell, Becton \& Dickinson) monoclonal ant body.

\section{Determination of the Labeling Index (LI)}

The LI was calculated as the ratio of the number of BrdU $\mathrm{I}_{\text {i }}$ beled cells to the total number of crypt cells. Only crypts $\mathrm{cl}$ through the longitudinal axis were considered, and the LI w: expressed as the mean of 10 crypts. 
Autoradiography

After immunocytochemical staining of BrdU incorporation, the tissue sections were dipped in photographic emulsion (Kodak, K2) and exposed for 4 weeks. The autoradiographs were developed by standard techniques and counterstained with hematoxylin.

\section{$\overline{9} . \overline{2}$ Results}

In a first series of experiments, the characteristics of in vivo labeling with BrdU with subsequent immunocytochemistry were investigated. Balb/c mice were injected intraperitoneally with respectively 50,5 and $0.5 \mathrm{mg} / \mathrm{kg}$ BrdU and were sacrificed 1 hour later. When tissue sections of the small intestine were stained with the monoclonal antibody, cells in the lower part of the crypts were darkly stained over the nucleus, whereas no labeling was observed in the villi (figure 1). Non-proliferative control tissue, such as liver and kidney, did not show labeled cells. Background staining in control sections appeared to be negligible. The $\mathrm{LI}$ of the small intestine was dependent on the
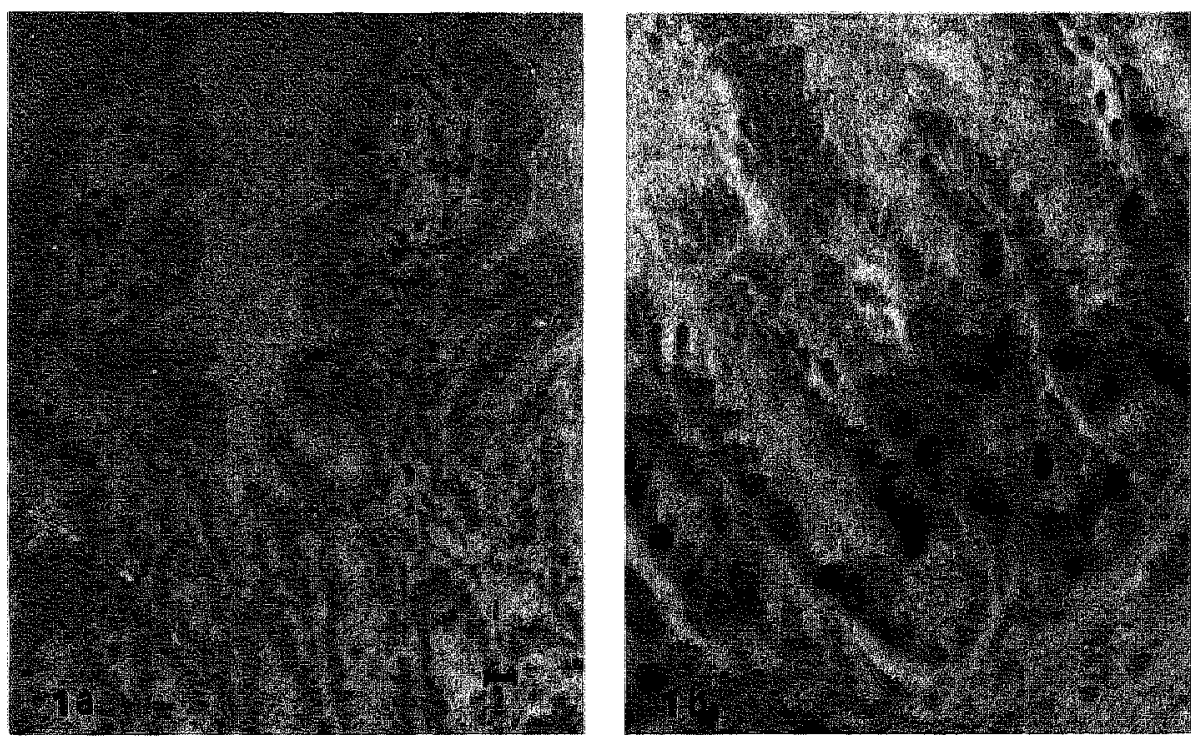

Figure 1 Small intestine of Balb/c mice stained with control serum (a) and MoAb llb5 (b). The bar represents $10 \mathrm{Hm}$. 
dose administered, i.e., a lower LI was observed at a dose of 0.5 $\mathrm{mg} / \mathrm{kg}$; no increment was observed at doses exceeding $5 \mathrm{mg} / \mathrm{kg}$ (table 1). To ascertain both the sensitivity and the specificity of the monoclonal antibody staining, in comparison to autoradiography, mice were injected with $25 \mu \mathrm{Ci}[3 \mathrm{H}]-\mathrm{BrdU}$, supplemented with unlabeled Brdu, to yield a final dose of 5 and $50 \mathrm{mg} / \mathrm{kg}$, respectively. When autoradiographs of peroxidase stained and $[3 \mathrm{H}]$-BrdU labeled tissue sections were analyzed, almost completely concordant nuclear localization of DAB precipitate and silver grains was observed at doses of 5 and $50 \mathrm{mg} / \mathrm{kg}$ (figure 2j. At 5 and $50 \mathrm{mg} / \mathrm{kg}$ the percentages of immunoreactive cells in the autoradiography positive group were $94.8 \%$ and $98.4 \%$, respectively, indicating somewhat higher sensitivity for a dose of $50 \mathrm{mg} / \mathrm{kg}$. The percentages of cells lacking immunoreactivity in the autoradiography negative group were $99.6 \%$ and $99.4 \%$, respectively, indicating equally high specificity.

In a second series of experiments, the dual staining of antigen expression and BrdU substituted DNA was investigated. Since acid denaturation, needed for unmasking BrdU binding sites, could affect the localization of anti-serotonin reactivity, serial tissue sections were cut. The slides were stained for serotonin immunoreactivity alone and serotonin immunoreactivity in combination with BrdU incorporation. However, serotonin immunoreactivity did not appear to be reduced in the double-staining technique (figure 3) nor was BrdU reactivity affected by the prior staining for serotonin.

\subsection{Discussion}

We have developed an immunocytochemical method for the simultaneous detection of antigen expression and BrdU substituted DNA. Serotonin immunoreactivity in intestinal endocrine cells

Table 1 The relationship between the dose of BrdU administered and the labeling index.

\begin{tabular}{lll} 
Dose $(\mathrm{mg} / \mathrm{kg})$ & LI & $( \pm$ SD $)$ \\
\hline 0.5 & 25 & $( \pm 7.8)^{*}$ \\
5 & 34 & $( \pm 9.0)$ \\
50 & $34.1( \pm 13.5)$ \\
$25 \mu \mathrm{Ci}$ & $38.9( \pm 18.4)$
\end{tabular}

* $\mathrm{p}<0.05$ student $-\mathrm{T}$ test 


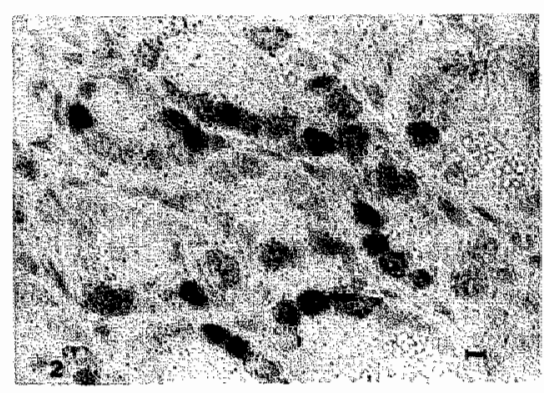

Figure 2 Combined immunocytochemistry and antoradiography on small intestine of Balb/c mice labeled in vivo wirh $25 \mu \mathrm{Ci}$ BrdU (final dose of $50 \mathrm{mg} / \mathrm{kg}$ body weight). The bar represents 4 in m.

was detected, by use of polyclonal anti-serotonin antibodies in a peroxidase diaminobenzidine technique. Subsequently, using monoclonal anti-BrdU antibodies, BrdU incorporated into DNA was detected in a peroxidase diaminobenzidine cobalt nitrate technique. BrdU-labeled cells showed a patchy pattern of nuclear staining, in agreement with the known heterogeneity in the rate and distribution of DNA synthesis in different parts of the chromatin during the course of the S-phase. Comparison of BrdU staining with autoradiographic detection of $\left[{ }^{3} \mathrm{H}\right]$-BrdU showed excellent agreement between the results obtained with these methods. Both sensitivity and specificity of the immunocytochemical technique were high at intraperitoneal BrdU doses of 5 and $50 \mathrm{mg} / \mathrm{kg}$.

Simultaneous detection of cytoplasmic or plasma membrane bound antigens and DNA synthesis related BrdU incorporation relies on the availability of an acid resistant staining after the first immunoreaction, for which we choose DAB. We have shown that acid denaturation of DNA, which is essential for unmasking BrdU antigenic sites, does not interfere with the formed DAB precipitate. In fact, this step serves a second purpose, since acid elution of antibodies and conjugates from the first reaction precludes the interference of peroxidase from the first step with BrdU localization. This technique can be applied to frozen or paraffin-embedded tissues and cytocentrifuge preparations. Alternative methods to obtain single-stranded DNA sequences have been described, including heat (17) or nuclease (18) digestion. Heat denaturation, however, is a rather aggressive method, which cannot always be applied to fragile material such as bone marrow cells. Moreover, both techniques do not obviate the need 

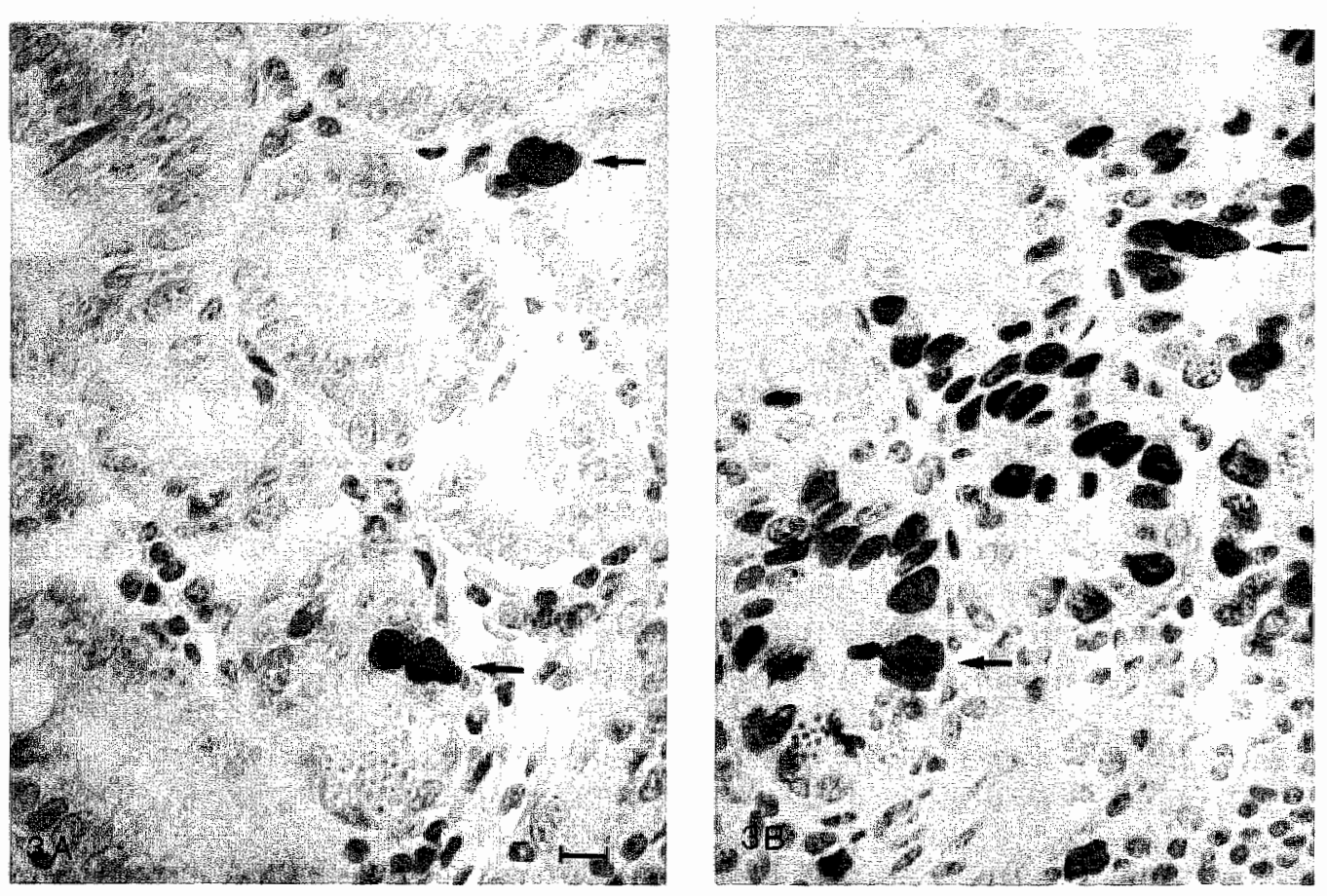

Figure 3 Serial tissue sections of murine small incestine stained with anti-serotonin (a) and antiserotonin and anti-BrdU bh. Arrows indledte serotornin positive cells. The bar represents $10 \mu \mathrm{m}$. 
for an additional elution of antibodies from the first staining reaction, and will therefore prolong the staining protocol. Although the immunocytochemical detection of BrdU incorporation as such is not new $(8,9)$, the technique described in the present paper has many new potential applications. For example, in phenotypically and cytokinetically heterogeneous cell populations, antigen expression can be studied as a function of progression through the cell cycle. Furthermore, this double labeling technique should allow cytokinetic analysis of phenotypically defined cell populations, such as normal or neoplastic white blood cells or solid tumor cells. Since no radioactive DNA precursors are needed, these applications can be studied using in vivo labeling; the feasibility of this approach in humans has already been described $(19,20)$. The technique described is not limited to in vivo labeling; in fact, we have studied human intestinal mucosa with ex vivo labeling finding similar results as described here. 


\section{References}

1. Tormstar MH, Tsou KC, Daly JM, Mullen JL, Stein TP, Miller EE, Buzby GP. Alteration of cumor cell kinetics by pulse total parenteral nutrition. Cancer 53: 1409-1415. 1984.

2. Spang-Thomsen M, Brumer $N$, Engetholm $S A$, Vindelow L. Estimation by flowcytometric DNA andysis of the effect of radiotherapy, hormone therapy and chemotherapy on human tumors grown in rude inice. Inmune-deficient. Animals. In tth International Work shop on Immume Deficient Animals in Exp Res, Chexbres 409 Karger, Basel, 1984), 1982.

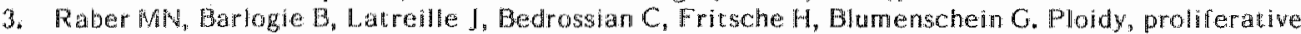
activity and estrogen receptor cortent in human breast cancer. Cytometry 3: 36-41, 1982.

4. Cray JW, Bogare E, Gavel DH. Ceorge YS, Moore DH Il. Rapid cell cycle analysis. II. Phase durations and dispersions from computer analysis of RC curves. Cell Tissue Kinetics $16: 457-471,1983$.

5. Pothen CS, Whimmann HE, Dobek K, Birch J, Codd TM, Horrochs L, Pedrick M, Tickle SP. Cell kinetic studies in the epidermis of mouse III. The percent labeled mitosis (PLM) technique. Cell Tissue Kinetics 18: $59-70,1985$.

6. Sted GG, Hanes S. The technigue of labelled mitosis: antysis by automatic curve-riting. Cell Tissue Kinetics 4: 93-105, 1971.

7. Dewn PN, Dolbeare F, Gratzier H, Rice GC, Gray JW. Cell cycle analysis using a monoclonal antibody to BrdU. Coll Tissue Kinetics 17: 427-436, 1984.

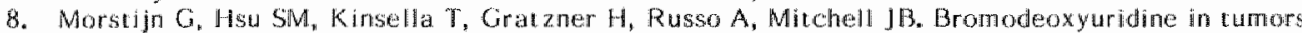
ard chromosomes decected whith a monoclonal artibody. J Clin Invest 72: 1844-1850, 1983.

9. Morstin G, Kinsella T, Hsu SM, Russo A, Gratzer H, Mitchell I. Identification of bromodeoxyuridine in malignant and normal cells following therapy: retationship to complications. Int I Radiation Oncology Biol Phys 10: 1441-1445, 1984.

10. Raza A, Spridamidis C, Ucar K. Mayers G, Banker. R, Preisler HD. Dutuble labeling of S-phase murine cells with bromodeoxyuridine and a specific DNA probe. Cancer Research 45: 2283-2287, 1985

11. Moran R, Darzymkewicz Z, St atino-Colco L, Melamed MR. Detection al 5-bonodeoxyuridina (Brdu) incorporation by monoclonal antibodies: rolle of the DNA denaturation step. J flistochem Cylochem 33: 821-827, 1985

12. Dobbare FA, Grazner HG, Pallavicini MG, Gray. W. Flowcytometric measurement of Lotan DNA content and imeorporated bromodeoxyuridine. Proc Nati Acad Sci USA 80: 5573-5577, 1983.

13. Gratzner HG. Monochonal ant body to 5-bromo and 5-iododeoxyuridine: a new reagent for detection of DNA replication. Science 218: 474-475, 1982.

14. Raza A, Uear K, Bhayand R, Kempski M, Preisler HD. Utility and sersitivity of ani-Brdu antibodies in assessing S-phase cells compared to autoradiography. Cell Biochemistry and Function 3 $149-153,1985$

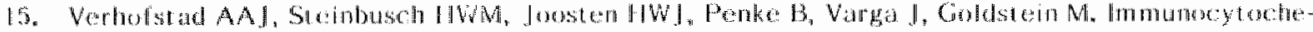

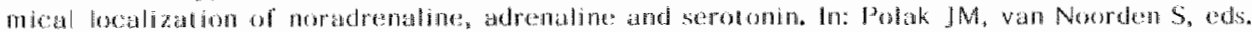

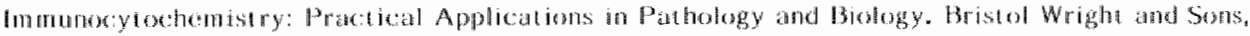
$143-160,1983$.

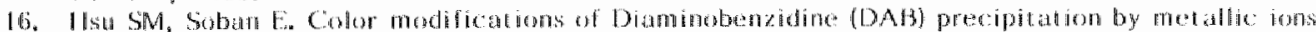

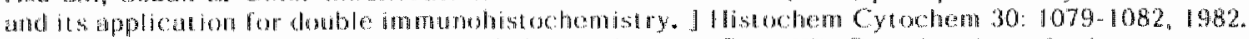

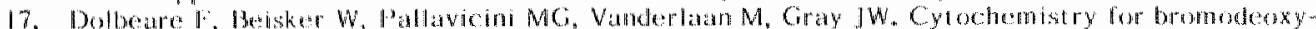

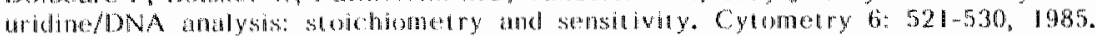

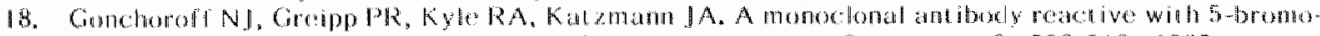

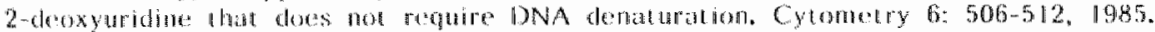

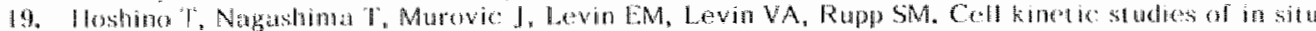

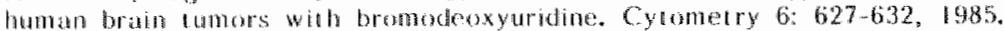

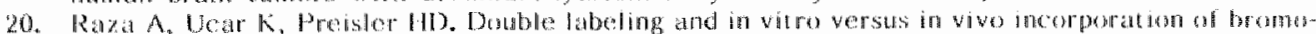

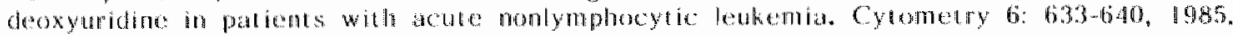


KINETIC STUDIES OF COLORECTAL CELL LINES GROWN IN VITRO AND IN VIVO 


\section{Introduction}

In a recent flow cytometric study of 279 cases of colorectal cancer, we were able to segregate patients into categories with diverse prognosis based on ploidy level and percentage of $\mathrm{S}$ phase cells of their tumors (1). Both aneuploid and high proliferative tumors showed a poorer survival as compared to diploid or low proliferative tumors. In addition, we found a strong correlation between ploidy level and the percentage of S-phase cells with tumors having low and aneuploid tumors having high numbers of S-phase cells (2). This finding suggests that there are differences in cytokinetic characteristics between diploid and aneuploid tumors. However, the estimation of numbers of Sphase cells from a single DNA histogram is a rather gross descriptor for cellular growth for several reasons. Firstly, due to the admixture of non-malignant and non-cycling diploid cells, the percentage of S-phase cells in diploid tumors may be spuriously low. Secondly, a static measurement can not fully describe a dynamic process such as cellular growth accurately. For example, no information is obtained about cell cycle duration and the number of actively cycling cells. These findings call for reevaluation of the relation between ploidy and proliferation with more appropriate methods.

Recently, Drewinko et al. (3) showed evidence for different cytokinetic properties between diploid and aneuploid tumors in a small series of 6 colorectal cancer cell $\|$ ines which were studied by a combination of FCM and $\left[{ }^{3} \mathrm{H}\right]$-thymidine autoradiography. Furthermore, it was shown that diploid tumors had a more differentiated phenotype. This is in agreement with our findings in the afore mentioned study (2), in which we were able to demonstrate that diploid tumors produce more mucin and less frequently produce CEA.

These findings prompted us to investigate in a larger series of colorectal cancer cell lines the relationship between ploidy, cytokinetic properties and differentiation. We specifically addressed the following questions: (i) do aneuploid tumor cell lines and their xenografts have higher growth fractions and shorter potential doubling and volume doubling times than diploid tumor cell lines, and (ii) do highly proliferative cell lines have less tendency to differentiate than less actively proliferating cell lines. To this end 13 colorectal cancer cell lines with different ploidy levels were propagated in vitro as well as in vivo as xenografts in nude mice and submitted to a detailled cytokinetic analysis using incorporation of bromodeoxyuridine (BrdU) $(4,5$, 
6). In addition, xenografts were characterized by immunohistochemistry for the expression of differentiation and tumor associated markers.

\section{iō.i Materials and Methods}

\section{Cell Lines}

Our studies were performed on the following 13 colorectal cancer cell lines: 5583-s, 5583-e, SW 48, HS 703T, SW 403, SW 480, SW 620, SW 1116, SW 1398, SW 2219, HT 29, Colo-205 and CaCo2. The 5583 cell lines were established at our own institution from a colloid carcinoma of the rectum. All other cell lines were obtained and described in detail elsewhere (7-11). All cell lines were maintained in Dulbecco's modified medium without antibiotics and supplemented with $10 \%$ heat inactivated fetal calf serum.

\section{Growth Kinetic Studies}

To determine the kinetics of in vitro growth, stock cultures of each cell line were harvested as a single cell suspension by trypsinization, and aliquots of approximately $5 \times 10^{5}$ cells were seeded into $25 \mathrm{~cm}^{2}$ culture flasks containing $5 \mathrm{ml}$ of nutrient medium and refed every two days for the duration of the experiments. Cell counts were made every 24 hours for up to 120 hours in a haemocytometer.

For the calculation of the S-phase duration (Ts) and the potential doubling time (Tpot), BrdU was added to each culture flask (10 i M final concentration). The cells were cultured in the presence of BrdU for 30 minutes, washed three times with PBS and refed with $5 \mathrm{ml}$ of nutrient medium $(t=0)$. The cells were harvested at different time intervals $(t=0,2,4,6$ and 8 hours) by trypsinization, washed twice with PBS and fixed in $70 \%$ ethanol.

For the calculation of the growth fraction, cells were cultured in the presence of BrdU (10 $\mu \mathrm{M}$ final concentration) for the time needed to reach the Tpot of a given cell line. The cells were harvested by trypsinization, washed twice with PBS and fixed in $70 \%$ ethanol. For the assessment of in vivo growth 10 wk old NMRI nu/nu mice were used. The animals were kept under sterile conditions in a laminar flow cabinet and fed with sterilized chow. Sterilized water was present ad libitum. Approximately $5 \times 10^{7}$ cells were inocculated subcutaneously at four 
different sites in the flanks of the mice. Tumor growth was measured by assessing the length (1) and the width (w) of the tumor every 3 days.

For the calculation of the Ts and Tpot; the animals were injected with BrdU $(50 \mathrm{mg} / \mathrm{kg}$ body weight by i.p. administration) when the tumors had reached a diameter of approximately 10 $\mathrm{mm}$. At a fixed time (ranging from 4 to 7 hours after injection) the animals were sacrificed by cervical dislocation and the tumors were excised. One half of the tumor was fixed in $10 \%$ neutral buffered formalin for immunohistochemistry and histo$\log y$, the other half was fixed in $70 \%$ ethanol for flow cytometry.

\section{Immunocytochemistry}

Details of the method have been described elsewhere (5). Briefly, ethanol fixed cells or tissue were digested with pepsin (Boehringer, $0.04 \mathrm{mg} / \mathrm{ml}$ in $0.1 \mathrm{~N} \mathrm{HCl}$ ) for 30 (cells) and 60 (tissue) min. at room temperature. Tissue digest was sieved through a $50 \mu \mathrm{m}$ nylon mesh to remove undigested tissue fragments. The obtained nuclei were washed twice in PBS and incubated in $2 \mathrm{~N} \mathrm{HCl}$ for $30 \mathrm{~min}$. at $37^{\circ} \mathrm{C}$, followed by washing twice in $0.1 \mathrm{M}$ sodiumtetraborate and once in PBT (PBS, BSA $0.1 \mathrm{mg} / \mathrm{ml}$, Tween 20, $0.05 \%, \mathrm{pH} 7.4)$. The pelleted nuclei were incubated in $100 \mu 1$ of monoclonal anti-BrdU antibody (clone Illb5) containing culture supernatant for 1 hour at room temperature, followed by washing twice in PBT. Monoclonal antibody binding was visualized by incubating the pelleted nuclei in $100 \mathrm{wi}$ of appropriately diluted FITC conjugated rabbit anti-mouse Ig $F\left(a^{\prime}\right)_{2}$ fragments (Dako F 313) for 1 hour at room temperature followed by washing twice in PBT. The nuclei were finally counterstained with $0.5 \mathrm{ml}$ of propidium iodide (PI) solution (Pl, Calbiochem $5 \mathrm{\mu g} / \mathrm{ml}$, RNAse Serva $0.1 \mathrm{mg} / \mathrm{ml}$ in PBS, pH 7.4) 15 minutes prior to flow cytometry.

\section{Flow Cytometry}

Nuclei were analyzed using a FACS IV Cell Sorter (Becton \& Dickinson, Sunnyvale, CA) equipped with a 4 Watt Argon lon Laser (Spectra Physics, model 164-05) tuned to $488 \mathrm{~nm}$ at 400 $\mathrm{mW}$ output. A $520 \mathrm{lp}$ filter was used to block scattered light. Log green fluorescence was measured through a $540 \mathrm{sp}$ filter and recorded as a measure of the amount of bound anti-BrdU antibody. Red fluorescence was measured through a $620 \mathrm{lp}$ filter and 
was recorded as a measure of the amount of bound PI.

\section{Histology}

Formalin-fixed and paraffin-embedded tissue sections were stained with haematoxylin and eosin and with the periodic acidSchiff reaction for total mucins, High-Iron-Diamine/Alcian Blue Stain (HIDAB) (12) for the detection of sialo- and sulphonucins and Grimelius (13) for the detection of argyrophil cells.

\section{Immunohistochemistry}

Formalin-fixed and paraffin-embedded tissue sections were stained for CEA (Dako, Al15) (14), SC (Dako, A 187) (15) and BrdU as described before $(4,6)$.

\section{Statistics}

Values were analyzed by linear regression techniques and doubling times were calculated from $\mathrm{ln} / \mathrm{slope}$. The volume of the tumor grown as xenograft was calculated at each time point using $\mathbf{V}=\left(\| \mathbf{w w}^{2}\right) / 2(16)$. The labeling index (LI) was measured as the total number of BrdU labeled cells. The relative movement of S-phase cells was calculated according to equation 1.

\section{$\mathbf{R M}=(\mathrm{Fl}-\mathrm{Fg}) /(\mathbf{F g m}-\mathrm{Fg}) \quad$ I (17)}

in which FI represents the mean DNA fluorescence intensity of BrdU labeled cells. Fg and Fgm represent the mean DNA fluorescence intensities of respectively $G_{1}$ - and $G_{2} / M$-phase cells. In case of in vitro growth, values were analyzed by linear regression techniques and $T$ s was calculated as the time at which $R M=1.0$. In case of in vivo growth equation 2 was used for the measurement of Ts.

$$
T s=(0.5 \times t) /(R M-0.5) \quad 2(17) .
$$

The Tpot was calculated according to equation 3, assuming unity value for $\lambda$.

$$
\text { Tpot }=\lambda x T s / L I \quad 3(16) \text {. }
$$

The cell loss factor was calculated using equation 4.

$$
\Phi=1 \text {-Tpot/Td } 4(16) \text {. }
$$

The growth fraction of the tumors grown as xenografts were assessed indirectly using

$$
\mathrm{GF}=\mathrm{LL} / \mathrm{L} \text { LIprol } \quad(16) \text {, }
$$

in which Liprol represents the labeling index of the exponentionally growing cells. 


\subsection{Results}

Table 1 presents the cytokinetic characteristics of each colorectal cancer cell line grown in vitro as analyzed by BrdU incorporation. The cell lines are grouped according to their ploidy level in diploid (DNA index $=1.0$ ), near-diploid (DNA index $>1.0$ and $<1.30$ ) and aneuploid (DNA index $\geqq 1.30$ ). In all cases the growth fraction was in excess of $90 \%$ except for SW 620, indicating exponential growth. There were no statistically significant differences between the three groups with respect to LI, Ts and Tpot.

When tumor cells were inocculated subcutaneously into the flanks of nude mice, all cell lines resulted in tumor growth. The xenografts showed continuous growth during the experiments (figure 1), with the exception of $\mathrm{CaCo} 2$, which remained stable in size during our observation period of 4 weeks. Table 2 presents the cytokinetic characteristics of the xenografts. The LI and the growth fraction were lower than were observed in vitro, indicating the presence of non cycling cells. Again, no statistilines are grouped according ro ploidy level in diploid, near-diploid and aneuploid.

\begin{tabular}{|c|c|c|c|c|c|}
\hline Group & Cell Line & $\mathrm{DI}$ & LI & $\mathrm{Ts}$ & Tpot \\
\hline diploid & $\begin{array}{l}5583-8 \\
5583-\mathrm{E} \\
H S 703 \mathrm{~T} \\
5 W 48 \\
\text { meames }\end{array}$ & $\begin{array}{l}1.01 \\
1.04 \\
0.98 \\
1.01\end{array}$ & $\begin{array}{l}38.4 \\
47.3 \\
32.0 \\
42.7 \\
40.1 \pm 6.5\end{array}$ & $\begin{array}{l}7.9 \\
7.8 \\
12.0 \\
10.3 \\
9.5+2.0\end{array}$ & $\begin{array}{l}20.6 \\
16.4 \\
37.5 \\
24.1 \\
24.6 \pm 9.1\end{array}$ \\
\hline $\begin{array}{l}\text { near- } \\
\text { diphoid }\end{array}$ & $\begin{array}{l}\text { SW } 480 \\
\text { SW } 1398 \\
\text { SW } 620 \\
\text { meantso }\end{array}$ & $\begin{array}{l}1.20 \\
1.22 \\
1.27\end{array}$ & $\begin{array}{l}34.8 \\
36.5 \\
55.8 \\
42.4 \pm 11.7 *\end{array}$ & $\begin{array}{l}8.7 \\
9.2 \\
8.8 \\
8.90 .3\end{array}$ & $\begin{array}{l}24.9 \\
25.3 \\
15.8 \\
22.0+5.4\end{array}$ \\
\hline aneuploid & 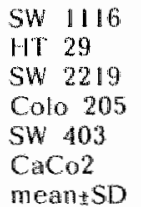 & $\begin{array}{l}1.57 \\
1.53 \\
1.70 \\
1.72 \\
1.50 \\
1.90\end{array}$ & $\begin{array}{l}22.1 \\
62.3 \\
59.8 \\
48.0 \\
42.8 \\
34.1 \\
44.9 \pm 15.3 *\end{array}$ & $\begin{array}{l}15.4 \\
10.0 \\
13.1 \\
8.3 \\
9.9 \\
11.2 \\
11.3 \pm 2.6 *\end{array}$ & $\begin{array}{l}69.7 \\
17.3 \\
21.9 \\
17.3 \\
23.1 \\
32.8 \\
30.3+20.1\end{array}$ \\
\hline
\end{tabular}

* student T-test not significant 

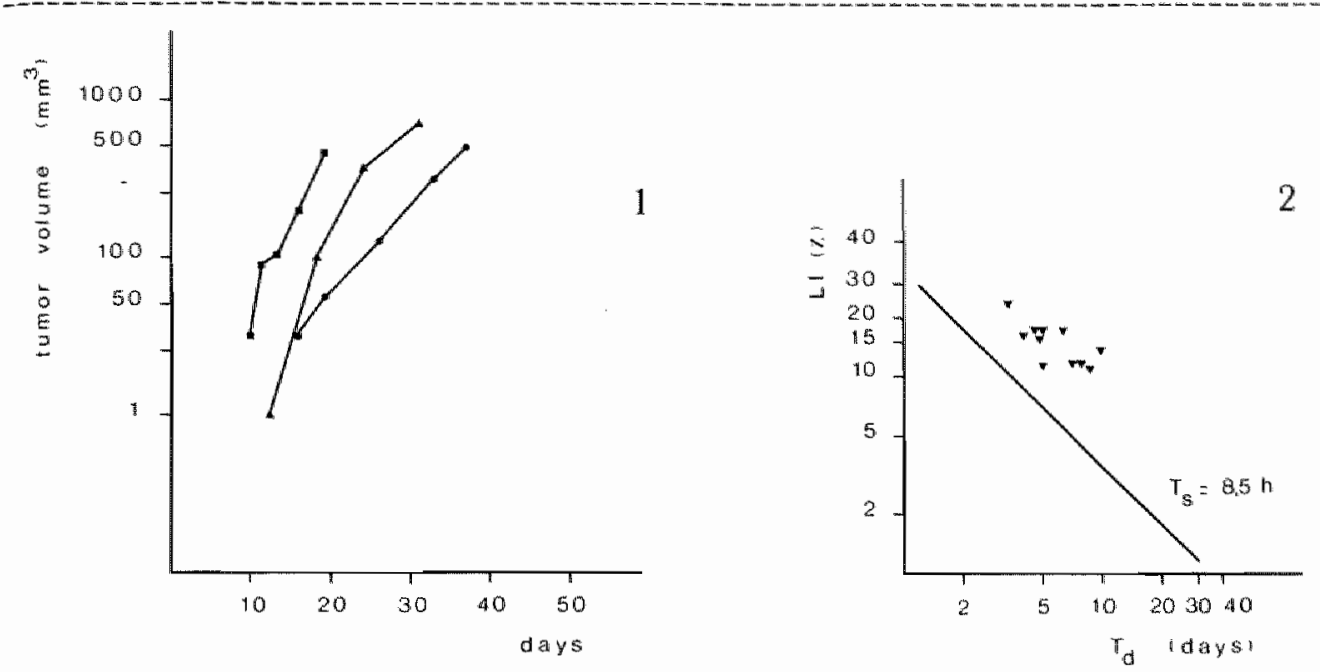

Figure 1 Growth curves of 3 colorectal cell lines grown as xenogralts in nude mice. (6) SW 2219, (4) Colo 205, (*) 5 w 480 .

Figure 2 Correlation between turnor volume doubling time and L 1 of 1 I colotectal cell lines grown as xenografts in nude mice. The calculated potential doubing times, based on an average S-phase duration of $8.5 \mathrm{~h} .$, as a function of the labeling indices are drawn as a straight line.

Table 2 Cytokinetic paramecers of colorectal cell lines grown as xenografts in nude mice. The cell lines are grouped according to ploidy level in diploid, near-diploid and anetiplobl.

\begin{tabular}{|c|c|c|c|c|c|c|}
\hline Group & Cell Line & $\mathrm{DI}$ & $\mathrm{H}$ & $\mathrm{Ts}$ & Tpot & $\mathrm{GF}^{\circ}$ \\
\hline diploid & 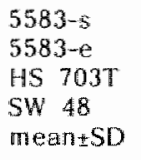 & $\begin{array}{l}1.01 \\
1.04 \\
0.98 \\
1.01\end{array}$ & $\begin{array}{l}17.6 \\
16.0 \\
14.0 \\
11.2 \\
14.7 \pm 2.8\end{array}$ & $\begin{array}{l}7.6 \\
6.6 \\
6.4 \\
8.3 \\
7.5 .0 .9\end{array}$ & $\begin{array}{l}43.1 \\
40.9 \\
55.4 \\
74.4 \\
53.5+15.4\end{array}$ & $\begin{array}{l}0.46 \\
0.34 \\
0.44 \\
0.26 \\
0.38+0.09\end{array}$ \\
\hline $\begin{array}{l}\text { near- } \\
\text { diploid }\end{array}$ & $\begin{array}{l}\text { SW } 480 \\
\text { SW } 1398 \\
\text { SW } 620 \\
\text { meantSD }\end{array}$ & $\begin{array}{l}1.20 \\
1.22 \\
1.27\end{array}$ & $\begin{array}{l}23.6 \\
11.9 \\
17.7 \\
17.7 \pm 5.9\end{array}$ & $\begin{array}{l}8.2 \\
12.4 \\
6.3 \\
9.0+3.1\end{array}$ & $\begin{array}{l}34.7 \\
106.4 \\
35.9 \\
59.0 \pm 41.0 *\end{array}$ & $\begin{array}{l}0.68 \\
0.33 \\
0.32 \\
0.44 .0 .21 *\end{array}$ \\
\hline aneuploid & $\begin{array}{l}\text { SW } 1116 \\
\text { HT } 29 \\
\text { SW } 2219 \\
\text { Colo } 205 \\
\text { SW } 403 \\
\text { CaCo2 } \\
\text { nuean+SD }\end{array}$ & $\begin{array}{l}1.57 \\
1.53 \\
1.70 \\
1.72 \\
1.50 \\
1.90\end{array}$ & $\begin{array}{l}12.0 \\
16.4 \\
11.8 \\
18.6 \\
16.5 \\
16.9 \\
15.4 \times 2.8\end{array}$ & $\begin{array}{l}8.5 \\
7.2 \\
10.0 \\
8.2 \\
12.2 \\
6.5 \\
8.8 \pm 2.0 *\end{array}$ & $\begin{array}{l}70.7 \\
46.3 \\
100 \\
44.0 \\
74.5 \\
40.2 \\
62.6+23.3\end{array}$ & $\begin{array}{l}0.54 \\
0.58 \\
0.20 \\
0.39 \\
0.39 \\
0.50 \\
0.40 .0 .21\end{array}$ \\
\hline
\end{tabular}

* student T-test not significant 
cally significant differences were observed, with respect to the LI, Ts, Tpot and GF, due to the large spread in individual values within each subgroup.

When characterized on morphological and (immuno)histochemical criteria, no striking differences between the three groups were observed (table 3). Almost all cell lines expressed CEA except SW 480, SW 620 and SW 2219. Moderately differentiated tumors were found in each group, which is also indicated by the presence of mucin production (only sialomucin) and SC immunoreactivity. Occasionally, argyrophilic cells were detected in some cell lines and in the central parts of the tumors necrosis was frequently observed.

In figure 2 the Ll's and the volume doubling times of the xenografts are plotted. For convenience the theoretical line, assuming no cell loss and an average Ts of $8.5 \mathrm{~h}$, was drawn. The individual measurements deviated from the theoretical line, indicating cell loss. There was a considerable variation in cell loss

Table 3 (Immunohistochemical characteristics of colorectal cell lines grown as kenograres in rude mice. The celt lines are grouped according to ploidy level in diploid, near-diploid and aneuploid. n.d. = not determined.

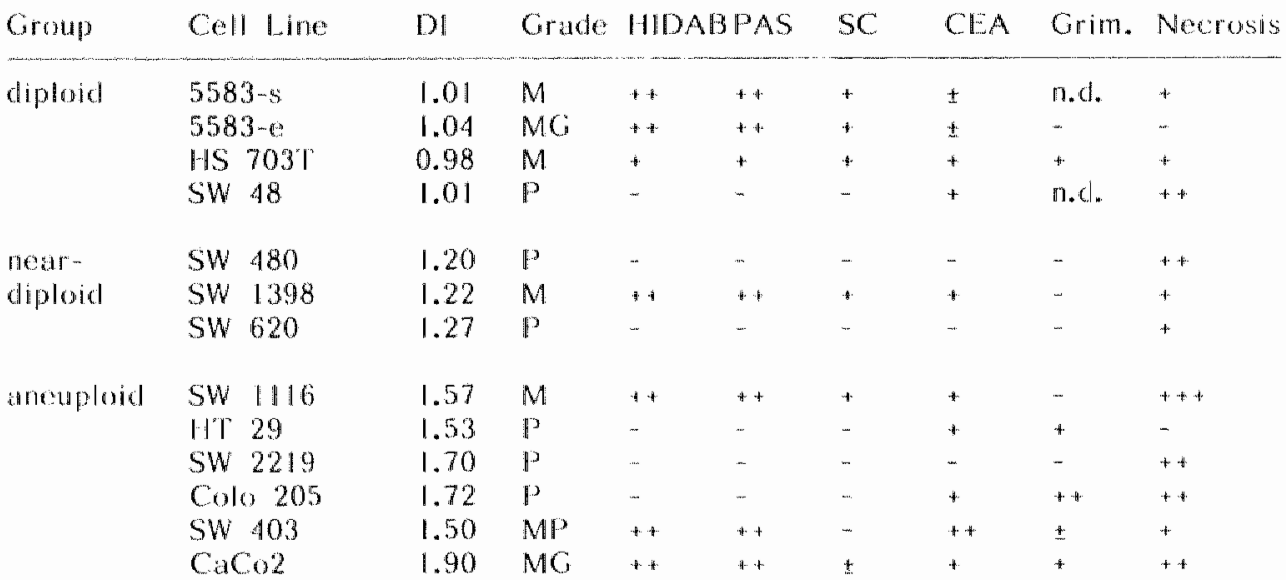


for different xenografts, since only a borderline significant relationship was found $(p=0.05)$. In moderately differentiated tumors the cell loss factor appeared to be highest. Regrouped according to the degree of differentiation, differences in the actual tumor growth, the Tpot and the GF were not statistically significant for both groups. However, there was a trend for longer volume doubling times and higher cell loss in moderately differentiated xenografts (table 4 ). In addition, moderately differentiated tumors were almost exclusively positive for PAS, HIDAB and SC, as compared to poorly differentiated tumors.

\section{$\overline{10} \overline{3}$ Discussion}

In a recent study of 279 colorectal cancer patients we found that low percentages of S-phase cells in a tumor were correlated with a better prognosis (1). Diploid tumors have also been shown to have a better prognosis than aneuploid tumors. We further-

Table 4 Growth characteristics of colorectal cell hines growm as xenografts an nude mice. The cell lines are grouped according to grade in moderately arnd poorly differentiated tumors.

\begin{tabular}{|c|c|c|c|c|c|c|}
\hline Group & Cell Line & $\mathrm{D} \|$ & Tpot & $G F$ & $\mathrm{Td}$ & Cell loss \\
\hline \multirow[t]{7}{*}{ Moderate } & $5583 \cdots \mathrm{s}$ & 1.01 & 43.1 & $0.46^{\circ}$ & 6.3 & 0.71 \\
\hline & $5583-\mathrm{e}$ & 1.04 & 40.9 & 0.34 & 4.8 & 0.65 \\
\hline & HS $703 \mathrm{~T}$ & 0.98 & 55.4 & 0.44 & 9.7 & 0.76 \\
\hline & SW 1398 & 1.22 & 106.4 & 0.33 & 7.2 & 0.38 \\
\hline & $S W 1 \| 16$ & 1.57 & 70.7 & 0.54 & 7.7 & 0.62 \\
\hline & CaCo2 & 1.90 & 40.2 & 0.50 & no growllin & 1.0 \\
\hline & mean $\pm S D$ & $1.29 \pm 0.37$ & $59.5 \pm 25.8$ & $0.44 \pm 0.08$ & $7.1 \pm 1.8$ & $0.69 \pm 0.2$ \\
\hline \multirow[t]{8}{*}{ Poorly } & SW 48 & 1.01 & 74.4 & 0.26 & 8.7 & 0.64 \\
\hline & $5 W 480$ & 1.20 & 34.7 & 0.68 & 3.3 & 0.56 \\
\hline & SW 620 & 1.27 & 35.9 & 0.32 & 4.6 & 0.67 \\
\hline & HT 29 & 1.53 & 46.3 & 0.58 & 4.1 & 0.53 \\
\hline & SW 2219 & 1.70 & 100 & 0.20 & 4.9 & 0.15 \\
\hline & Colo 205 & 1.72 & 44.0 & 0.39 & 4.9 & 0.63 \\
\hline & SW 403 & 1.50 & 74.5 & 0.39 & n.p. & n.p. \\
\hline & mean $₫ S D$ & $1.42 \pm 0.27 *$ & $58.5 \pm 24.7 *$ & $0.40_{ \pm} 0.17 *$ & $5.1 \pm 1.9 *$ & $0.53 \pm 0.19 *$ \\
\hline
\end{tabular}

*student T-test not significant 
more observed a strong correlation between proliferative activity as defined by the S-phase fraction and the DNA index (2). These findings suggest that diploid tumors might have low proliferative activity and aneuploid tumors a high proliferative activity. We therefore performed a detailed cytokinetic analysis of 13 colorectal cancer cell lines with different ploidy levels, in order to test this hypothesis. The results presented in this paper demonstrate that there are no statistically significant differences between diploid, near-diploid and aneuploid cell lines with regard to labeling index (LI), growth fraction (GF) and potential doubling time (Tpot) neither in vitro nor in vivo. These findings do not entirely exclude the possibility that in patients diploid cancers have a lower proliferative activity than aneuploid cancers. The tumor cell kinetics are not only determined by inherent tumor cell characteristics but may be also subject to host factors.

A further extension of this study concerned the relation between differentiation, proliferative activity and ploidy. The association of a high level of differentiation with better prognosis (15) does suggest that well differentiated tumors might be diploid rather than aneuploid and show less proliferative activity. Along these lines, Drewinko et al. (3) suggested that colorectal cancer cell lines might be classified into three biologically distinct groups. Group I consisted of the most differentiated cells showing gland formation, abundant mucin production and ciliary development, while group III consisted of undifferentiated cells, with numerous multinucleated cells as outstanding characteristic. The modal chromosome number, increased from group I to group III which was also reflected in the DNA content. The proportion of proliferating cells was higher in group I than in group III. Lack of CEA production was a characteristic feature of group II cells. The most striking observation was that only cell lines of group I could easily be propagated in nude rats. Cells of group II showed initial growth and then regressed while cell lines of group III could not be grown in nude rats at all. The authors suggested that the possibility of xenografting might be an important determinant for the biological behaviour of human carcinomas.

Several of our results are at variance with those of Drewinko et al. (3). First of all we did not find any correlation between differentiation, ploidy and growth characteristics, neither in vitro nor in vivo. Moderately differentiated as well as poorly 
differentiated cells occurred in all three ploidy groups and when the cell lines were grouped according to differentiation no significant differences in growth characteristics or ploidy emerged, largely due to a striking variability between the cell lines. We obtained a $100 \%$ take rate in our xenografting experiments and tumor regression did not occur.

Our experiments, however, differ from those of Drewinko et al. (3) in several respects. We studied 13 colorectal cancer cell lines, including 5 of the 6 lines used by Drewinko et al. (3). The culture media were different, which may account for small differences in cytokinetic parameters, and also the method and the calculations for determining cytokinetic parameters. We used incorporation of BrdU with subsequent immunocytochemical detection instead of $\left[{ }^{3} \mathrm{H}\right]$-thymidine and autoradiographic techniques. Consequently, different calculations were used. As shown by Begg et al. (17), however, results obtained by single sampling of BrdU labeled cells are comparable with those obtained by determining the percentage of labeled mitoses. In addition, the cytokinetic parameters which we have measured in xenografts, are comparable to those measured in human colorectal cancer after in vivo administration of $\left[{ }^{3} \mathrm{H}\right]$-thymidine (18). Another difference is that in our study differentiation was scored on (immuno)histological parameters in contrast to the cytological criteria applied by Drewinko et al. (3). We could apply immunohistological criteria because all xenografted cell lines resulted in tumor growth. The observed differences in take rates may be accounted for by differences in the state of immunocompetence of nude mice, which we used, and nude rats as applied in the study of Stragand et al. $(20,21)$. The results presented indicate that there are no unequivocal relations between differentiation, ploidy and proliferation. A simple explanation for this conclusion may be that poorly differentiated tumor cells do not necessarily all proliferate.

A striking finding in our study was that, given the differences between the volume doubling time of the xenografts and the potential doubling time, cell loss is an important determinant of tumor growth.

Cell loss was more pronounced in moderately differentiated than in poorly differentiated tumors. For instance, the moderately differentiated cell line $\mathrm{CaCo} 2$ showed no increase in size during an observation period of 4 weeks. Pulse لabeling with BrdU, however, resulted in a labeling index of $16.9 \%$, indicating a cell 
loss factor of approximately 1.0. However, the extent of necrosis observed histologically could not account for the calculated cell loss. It is useful to distinguish two types of non induced cell death in tumors: wholesale cell death at necrotic boundaries, and isolated cell death. Wholesale cell death is the result of inadequate supply of essential nutrients to some parts of the tumor. Individual cell death, or apoptosis (22) occurs in many normal tissues and is frequently associated with "physiological" cell death. Also in neoplastic tissues, apoptosis has been observed and a possible stimulus for cell death could be host factors, such as natural killer cell activity. However, no differences were observed in the extent of infiltration between moderately and poorly differentiated xenografts. Therefore, the most likely explanation for the more pronounced cell death in moderately differentiated xenografts is terminal differentiation leading to a programmed cell death.

Furthermore, care must be be taken to include take rates as a discriminant since the ability to grow in nude animals is not solely an intrinsic property of the tumor but also or largely defermined by the immune status of the animals used. Interesting from a biological point of view is the observation that in aneuploid tumors the duration of S-phase cells was not significantly longer than in diploid tumors. In other words, with a larger total amount of DNA per cell and a constant duration of the DNA synthesis phase, the rate of DNA synthesis must be increasing. The most likely explanation of this phenomenon is that with an increase in total cellular DNA, the total number of replicons active during DNA synthesis must be increasing accordingly.

Our findings might have consequences for clinical research of anticancer agents. The potential of colorectal tumors to respond to S-phase specific anticancer agents (i.e. 5-fluorouracil) will depend on the proliferative status of the targeted tumor. Degree of differentiation nor the ploidy level seems to be able to segregate tumors with differential proliferative potential. However, individual differences in proliferative potential were noticed and might be exploited to predict the response to therapy. In conclusion, colorectal tumors can not invariably be classified based on differentiation characteristics into two groups differing in potential growth. However, moderately differentiated tumors showed a tendency for a greater cell loss. The more favourable clinical course of patients with diploid tumors may therefore not 
be explained by a decreased potential for growth. However, detailed and dynamic cytokinetic studies in colorectal cancer patients are needed to settle the issue whether the relation between ploidy and percentage of S-phase cells is due to technical artifacts or real differences in proliferative characteristics of the tumor cell population. 


\section{References}

1. Schutle B, Reynders MMJ, Wiggers T, Arends JW, Volowics L, Bosman FT, Blijham GH. The progmostic significance of DNA content and proliferative activity in large bowel carcinoma. Cancer Res (accepted).

2. Schutte B, Reynders MMJ, Wiggers T, Arends JW, Volovics L, Bosman FT, Bijham GH. Ploidy level and proliferative activity in colorectal carcinoma: correlation with clinicopathological and immunocytochemical parameters (submitted).

3. Drewinko B, Yang LY, Leibovitz A, Barlogie B, Lutz D, Janssen B, Stragand JJ, Trujillo JM. Cetlular discriminants for a biological classification of human colon carcinoma. Cancer Res 44: 4241 $4253,1984$.

4. Schute B, Reymders MMJ, Bosman FT, Blijham GH. The effect of tissue fixation on anti-bromodeoxyuridine immunohistochemistry. I Histochem Cycochem (in press).

5. Schute B, Reynders MMJ, wan Assche C, Hupperets PSG J, Bosman FT, Blijham GH. Studies with anti-bromodeoxyuridine antibodies. I. An improved method for the immunohistochemical detection of BrdU labeled nuclei using flow cytometry. Cytometry (in press).

6. Schutte B, Reynders MMJ, Bosman FT, Blijham GH. Studies with anti-bromodeoxyuridine antibodies. II. Simultaneous immunocy tochemical detection of antigen expression and DNA synthesis by in wivo labeling of mouse intestinal mucosa. I Histochem Cytochem 35: 371-374, 1987.

7. Leibovitz A, Stinso JC, McCambs III WB, McCoy CE, Mazur KC, Mabry ND. Classificiation of human colorectal adenocarcinoma cell lines. Cancer Res 36: 4562-4569, 1976.

8. Pinto M, Robine-Leon S, Appay MD. Enterocyte-like differentiation and polarization of the human colon carcinoma cell line CaCo2 in culture. Biol Cell 47: 323-330, 1983.

9. Jogh J, Trempe G. New human tumor cell lines. In: J Fogh (ed). Human tumor cells in vitro, pp. 115-141, New York, Plenum Press, 1975.

10. Fogh J, Fogh JM, Orfeo T. One hundred and twenty - seven cultured human cumor cell lines producing tumors in nude mice. J Natl Canc Inst 59: 221-226, 1977.

11. Quinn LA, Moore GE, Morgan RT, Woods LK. Cell lines from human colon carcinoma with unusual cell products, double minutes, and homogeneously staining regions. Cancer Res 39: 4914-4924, 1979.

12. Wiggers $T$, Arends JW, Verstijnen $K$, Moerkerk PM, Bosman FT. Prognostic signilicance of CEA inmunoreactivity patterns in large bowel carcinoma tissue. Br J Cancer 54: 409-414, 1986.

13. Spicer SS. Diamino methods for differentiating mucosubstances histochemically. I Histochem Cytochem 13: 211-234, 1965.

14. Grimelius L. A silver nitrate stain for alpha-1-cells in human pancreatic islets. Acta Soc Med Ups 73: 243-270. 1968.

15. Arends JW, Wiggers T, Thijs CT, Verstignen $\mathrm{K}$, Swaen GJ, Bosman FT. The value of secretory component ( $\mathrm{SC}$ immunoreactivity in diagnosis arad prognosis of colorectal carcinomas. Am J Clin Pachol 82: 267-274, 1984 .

16. Steel GG. Growth kinetics of tumours. Clarendon Press (Oxford), 1977.

17. Begg AC, MCNally NJ, Schrieve DC, Karchner H. A method to measure the duration of DNA synthesis and the potentlal doubling time from a single sample. Cytometry 6: 620-626, 1985 .

18. Terz JJ, Curutchet HP, Lawrence Jr J. Analysis of the cell kinetics of human solid tumors. Cancer 28: $1100-1110,1971$.

19. Drewinko B. Moskwa P, Lotzova E, Trujillo JM. Succesful heterotransplantation of human colon cancer cells to athymic animals is related to tumor cell differentiation and growth kinetics and to host natural killer cell activity. Invasion and Metastasis 6: 69-82, 1986,

20. Stragand IJ. Barlogie B, White RA, Drewinko B. Biological properties of the human colonic adenocarcinoma cell line SW 620 grown as a xenograft in the athymic mouse. Cancer Res 41: 3364-3369, 1981.

21. Stragand II, Drewinko B, Henderson SD, Grossie B, Stephens LC, Barlogie B, Trujillo JM. Growt h characteristics of human colonic adenocarcinomas propagated in the Rowett at hymic rat. Cancer Res 42: 31\|1-3115, 1982.

22. Wyllie AH. The biology of cell death in tumors. Anticancer Research 5: 131-136, 1985. 
971

\section{DISCUSSION}




\section{Introduction}

What is generally recognized as the cancer cell is in reality but a late product of a complex set of biologica! interactions, described as carcinogenesis. The fundamental concepts of tumor progression as postulated by Foulds (1) and Nowell $(2,3)$ have as central theme the idea that increasing genetic alterations generated by random somatic mutational events are responsible for tumor cell heterogeneity and progression of tumor cells to increasingly malignant and less regulator responsive states. Since not all neoplastic cells show a higher mutational frequency than normal cells (4), processes such as rearrangement and DNA methylation (5), may also be involved in tumor cell progression. Irreversible changes of the cellular genome could result in autonomously growing cells with the typical morphological characteristics of cancer cells with the ability to invade and to metastasize. Evidence is accumulating that the socalled oncogenes are among the major target genes for the genetic alterations leading to neoplasia (6-9). Under normal conditions this group of genes is believed to play a major role in the regulation of cellular growth and differentiation. In neoplasia oncogenes are of ten found to be pointmutated (H-Ras), translocated or amplified (9). However, it is unlikely that a single oncogene activation event is sufficient for the malignant change (6).

\section{Ti. IT Aneuploidy}

It is beyond the skope of this discussion to give a detailed summary on carcinogenesis. However, as the preceeding discussion has pointed out, subtle changes in the genome such as chromosomal rearrangements or deletions, gene amplifications or point mutations might be responsible for the abnormal gene expression leading to tumor development. Gross deviations in cellular DNA content (aneuploidy) as measured by flow cytometry are probably epiphenomena rather than primary events in tumor development. The sensitivity of flow cytometry does not allow the detection of aberrations involving less than $5 \%$ of the total cellular genome. In addition, balanced chromosomal translocations, which do not result in altered net cellular DNA content, remain undetected. Evidence that aneuploidy is a rather late event in tumor development comes from the incidence of aneuploidy in the adenoma-carcinoma sequence. In colorectal adenomas, which are considered to be the main precursor lesions for colorectal cancer, the incidence of aneuploidy is low (6 to 
$27 \%)(10,11)$ as compared to that in colorectal carcinomas $(40$ to $70 \%$ ) (12-16). In other words in the development of malignant neoplasia aneuploidy is a relatively late phenomenon. The bimodal distribution of DNA indices, showing clustering of tumors in either a near-diploid or a triploid-tetraploid mode, suggest that high DNA content is achieved by a process of polyploidization with subsequent loss of chromosomes. Severa] mechanisms could cause polyploidization such as nondisjunction, endoreduplication or cell fusion.

\subsubsection{Biological significance of aneuploidy}

In chapter 3 we have shown that aneuploidy is often associated with a loss of differentiation characteristics. Mucin production, which is considered to be a functional property of mature mucosal goblet cells, was decreased in aneuploid tumors. In contrast, the expression of CEA, a tumor associated marker, was more frequently observed in aneuploid tumors. However, no tendency was observed for an increased expression of SC and a higher degree of morphological differentiation in diploid tumors. In chapter 4 evidence for clonal selection in metastatic disease is presented. Although no dramatic differences in phenotype were observed, we found changes in ploidy level in a minority of cases. Finally, in chapter 5 evidence is presented that patients with aneuploid tumors have a more unfavourable clinical course to diploid tumors.

These data are in agreement with the concept of the clonal evolution of tumor cell populations $(1,2,3)$. According to this theory tumor progression is due to an acquired genetic lability permitting stepwise selection of variant sublines of neoplastic cells. Most variants will be eliminated in time, but the clones which possess a selective advantage will emerge as a predominant subpopulation. Aneuploidy seems to be indicative for such selection towards higher malignancy. However, differentiation characteristics and ploidy level were evaluated independently at a cell population level. It cannot be ruled out that in some cases different cells were identified. For instance, cells with a diploid DNA content may be of lymphoid or stromal origin. In addition, small subpopulations of tumor cells with a different ploidy level could remain undetected. This problem can be overcome by measuring antigen expression and DNA content on the same cells. This approach would require the isolation of single 
intact tumor cells from fresh tumor tissue. Recently, such dual staining protocols have been described, which use cytokeratin expression to separate lymphoid and stromal cells from epithelial cells in bladder carcinomas (17). In a similar approach DNA analysis and the immunocytochemical detection of differentiation markers or tumor associated markers could be combined (18) in order to (i) study the cell cycle dependent marker expression and (ii) increase the chance of detecting small subpopulations of tumor cells with a different phenotype.

\subsubsection{Clinical relevance of aneuploidy}

In chapter 5 we have shown that patients can be segregated into subgroups with different prognosis on the basis of the tumor cell DNA content. At this stage, aneuploidy could be correlated with response to therapy in clinical trials. As outlined in chapter 1 , evidence has been presented for some beneficial effect of post-surgical treatment with infusion of the liver with 5-fluorouracil or combined radio- and chemotherapy in colonic and rectal cancer. Aneuploidy could be used to identify patient subgroups that may benefit from such treatment strategies. The objective of such analyses is the tailoring or individualization of therapy by identification of suitable patient subcategories.

\section{$11 . \overline{2}$ Cell kinetics}

By measuring the DNA content of cells, obtained from tumor biopsies, information is obtained about the number of $S$-phase cells. Ideally, the number of S-phase cells is indicative for cell growth, since a prerequisite for cell division is the reduplication of the DNA. Therefore, the more cells occupied with DNA synthesis, the faster a cell population is growing. However, the number of S-phase cells does not only depend upon the rate of entry of cells into S-phase but also on the duration of the Sphase. Furthermore, diploid tumors, admixture of unknown qualities of diploid infiltrating lymphoid and stromal cells would lead to an underestimation of the proliferative activity. Other techniques for the calculation of cell kinetic parameters have been described (19) including mitotic index, stathmokinetic methods and thymidine labeling. Determination of the mitotic index is one of the oldest methods. Its basic principle is the scoring of mitotic figures as a measure of proliferative activity, since 
growth occurs by cell division. As is true for the number of Sphase cells, the mitotic index not only depends on the rate of entry of cells into mitosis but also on the duration of mitosis. Stathmokinetic methods measure the rate of accumulation of cells into metaphase after administration of agents capable of interrupting the progression of cells through the mitotic cycle. Often these blocks are irreversible and cell populations are perturbed. The thymidine labeling index is the most widely applied technique for the measurement of kinetic parameters. This technique is based on the incorporation of $\left[{ }^{3} \mathrm{H}\right]$-thymidine into the DNA of reduplicating cells. Cell kinetic data can be obtained after pulse or continuous labeling of cell populations using fraction of labeled mitoses (FLM) and continuous labeling curves (CLC) respectively. The first method is based on the appearance of labeled mitoses as a function of time after administration of the label. Some investigators have used double labeling with $\left[{ }^{3} \mathrm{H}\right]$ - and $\left[{ }^{14} \mathrm{C}\right]$-labeled thymidine and scored changes in the coincidence of the labels in individual cells. These changes in coincidence of label are indicative for the duration of S-phase. The CLC method measures the accumulation of the number of labeled cells as a function of time.

Also, using autoradiography, grain count halving can be used for the calculation of the cell cycle duration. When cells divide after having replicated their DNA in the presence of $\left[{ }^{3} \mathrm{H}\right]$-thymidine, two daughter cells are produced with a radioactive label content of on the average half of that of the parent cell. In this way at each generation time there is a halving of the grain count.

Disadvantages of these techniques are the laborious and time consuming autoradiographic procedures and the need for radioactive precursors. Recently, a new method has been described using the immunocytochemical detection of BrdU incorporated into the cellular DNA of replicating cells (20). BrdU is a synthetic analog of thymidine in which the methyl group is substituted by a bromine atom. The bromine atom is similar in size to a methyl group and BrdU therefore closely imitates thymidine in its cellular metabolism. It is incorporated into DNA and shows competitive inhibition with thymidine $(21,22)$. Furthermore, it is catabolized rapidly on in vivo administration $(23,24)$. No skin or bone marrow toxicity is observed after in vivo administration at low dosages to patients, making this analogue extremely usefull for clinical cell kinetic research. 


\subsubsection{Immunocytochemical detection of $\mathrm{BrdU}$}

In chapter 7 we described the generation of a monoclonal antibody against BrdU. No crossreactivity of this antibody with structurally related nucleotides were observed. In addition, a new method for the bivariate BrdU/DNA analysis using flow cytometry was developed. The increased sensitivity of the method allows the detection of slowly cycling cells, which otherwise might escape detection. Furthermore, when applied to kinetic studies in patients, the dosage of Brdu necessary for reliable measurements can be decreased. Using bivariate BrdU/DNA analysis detailed kinetic information such as phase transit times, cell cycle duration and growth fraction can be obtained with CLC or an approach similar to FLM. Recently, Begg et al (25) described an elegant approach to in vivo kinetic studies in patients using a single sample. Here the increase of the mean DNA content of BrdU labeled cells after a known interval of time after pulse labeling is a measure of the progression of the cells through the S-phase. In chapters 8 and 9 methods for the detection of BrdU labeled cells in tissue sections were established either as a single staining protocol or in combination with antigen expression. The latter method can be used to address fundamental questions regarding (i) the topographical localization of proliferation in relation to vascularization, (ii) tumor differentiation and (iii) influence of basement membrane components on proliferation.

\subsubsection{Biological significance of tumor cell kinetics}

To date there is some controversy regarding the relevance of cell kinetic parameters such as LI, Ts, Tpot and GF in relation to tumor growth. Steel (19) showed that for different tumor types such as adenocarcinomas, squamous cell carcinomas, sarcomas, melanomas and lymphomas there is no correlation between $\mathrm{LI}$ and volume doubling time. This would imply that cell production is by no means the only determinant of the rate of tumor growth. The rate of cell loss also determines the volume increase of a tumor.

Our data presented in chapter 10 , using colorectal cell lines grown as xenografts in nude mice, show that on the average the LI correlates with the tumor volume doubling time. However, in individual tumors such a correlation may not be found, indicating the importance of cell loss in determining volume doubling time. When grouped according to degree of differentiation, mo- 
derately differentiated tumors tended to show more frequently higher cell loss values than poorly differentiated tumors. This indicates that also within one tumor type, the cell production rate is not the most important determinant of tumor growth. In tumors showing the highest degree of differentiation, the highest levels of cell loss were found. The degree of necrosis was similar for all xenografts. Therefore, individual cell loss by the process of apoptosis, could be the major discriminant. The most likely mechanism for this individual cell loss would be terminal differentiation leading to a programmed cell death. To clarify this issue detailed cytokinetic analysis is needed preferably on primary human tumors transplanted into nude animals. In this way the relation between histological characteristics and growth rate can be further investigated. Also the microarchitecture of tumors in relation to the vascular system and the influence of host factors on tumor growth are of interest. These aspects could be studied by transplanting tumors at different sites (subcutaneously, intrasplenic, intracaecal and intracerebellar) in different immune deprived animals.

Recently, suitable tools to identify the translational and transcriptional activity of oncogenes, such as DNA probes and monoclonal antibodies directed against the gene products, have become available. By adapting techniques, using these tools, for flow cytometry, new areas with regard to mechanisms responsible for the triggering of proliferation and differentiation can be investigated.

\subsubsection{Clinical relevance of tumor cell kinetics}

Kinetic parameters such as LI, GF and Tpot measured in vivo can be used to predict the response to therapy. Some examples of the usefulness of this approach have been described. For instance, alterations in LI after irradiation have been shown to confer prognostic information (26). Furthermore, Fowler et al. (27) presented evidence that effective doubling times of clonogenic cells in human tumors during multifraction radiotherapy are similar to the pretreatment potential doubling time. Therefore, the beneficial effect of multifraction radiotherapv would be greatest in tumors having short pretreatment potential doubling times, because repopulation of the tumor during therapy will be limited. Also, the measurement of kinetic parameters using BrdU incorporation either in vitro or in vivo might help 
to elucidate mechanisms of combination chemotherapy (28) or biological response modifiers such as Interferon (29). However, kinetic parameters such as LI, GF or Tpot could turn out to be to inaccurate in terms of predicting response to therapy. Response to cytotoxic damage is determined by the balance between slowly proliferating stem cells and a larger rapidly proliferating group of cells that act to amplify the cell production rate to the required level. In response to stress the stem cells may accelerate and increase their output while more divisions may occur in the amplification compartment. These slowly proliferating stem cells could be insensitive to proliferation dependent agents and thereby responsible for the failure to cure the tumor. Therefore, it would be important to try to determine the proportion, the proliferative characteristics and the recruitment properties of stem cells.

Another promising application of cell kinetic research, becoming feasible with the new methods described, is the identification of abnormal colonic mucosal proliferation in preneoplastic conditions, for example in patients suffering from colitis ulcerosa or in patients with adenomas. Recent evidence suggest that this abnormal proliferation may be reversible, which might decrease the chance of tumor formation (28). Research in this area could contribute to the prevention of colorectal carcinomas.

\subsection{Concluding remarks}

The technique developed and described in the second part of this thesis is an important tool in the study of tumor cell kinetics both in vivo or ex vivo in patients or in experimental animals and in vitro, because (i) BrdU can be administered without any direct toxicity, (ii) algorithms necessary for the calculation of kinetic parameters are already present and (iii) the immunocytochemical detection of BrdU incorporation is relatively simple. However, since tumor growth is determined by a complex combination of factors the kinetic approach to cancer can not be pursued in isolation. It must be seen as one facet of describing tumor cell behaviour. 


\section{References}

1. Foulds L. Neoplastic Development. Vol. 2. London, Academic Press Ina., 1975.

2. Nowell PC. The clonal evolution of tumor cell populations. Science 194: 23-28, 1976.

3. Nowell PC. Mechanisms of tumor progression. Cancer Res 46: 2203-2207, 1986.

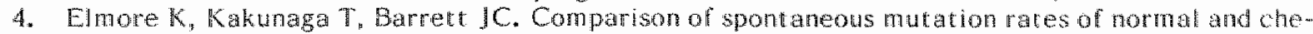
mically transformed human skin throblasts. Cancer Res $43:$ : $1650-1655,1983$.

5. Jones PA. DNA methylation and cancer. Cancer Res $46: 461-466,1986$.

6. Duesberg PH. Activated proto-oncogenes: sufficient or necessary for cancer. Sclence 222.669-67\%, 1985.

7. Dubbcoo R. Oncogenes, cancer and development. In: Theories and Models in Cellutar Transfonta tion. Academic Press Inc. London: $1-9,1985$.

8. Sachs L. Nomal regulators, oncogemes and the reversibility of malignancy. Cancer Strveys $3: 219-$ 228. 1984 .

9. Stamon DI, de Kemion JB, Verna JM, Cline MJ. Expression of celluar oncogenes in hnman malignancies. Science 224: 256-262, 1984.

10 Quitke P. Fozard JBJ, Dixon MP, Dyson JED, Giles GR, Bind CC. DNA aneuploidy in colorectal Carcinomas. Br J Cancer 53: $477 \sim 481,1986$.

11. Van den Ingh HF, Griflioen G, Comelisse CJ Flowcytometric detection of ancuploidy in colorectal cancinomas. Cancer Res 45: $3392-3397,1985$.

12. Wolley RC, Schreiber K, Koss LG, Karas M, Stherman A. DNA distriburion in humban colon Carcinomas and is relationship to clinical behaviour. INCI 69: 15-22, 1982.

13. Melamed MR, Enker WE, Banner P, Janov A, Kessier G, Darzynkiewicz Z. Flowcytometry of colo rectal carcinoma with three year follow-up. Diseases of the Colon ${ }^{2}$ Rectum 29: 184-186, 1986.

14. Kokal W, Scheibani K, Terz J, Harada JR. Tumor DNA content in the prognosis oll colorectal carcinonas. IAMA 255: 3123-3127, 1986.

15. Armitage NC, Robins RA, Evans DF, Tumer DR, Baldwin RW, Hardcastle JD. The influence of rumour cell DNA abnormalities on survival in colorectal cancer. Dr I Surg 72: 828-830, 1985 .

16. Schutre B. Reynders MMI, Wiggers T, Arends JW, Volovics L., Bosman FT, Blijhan GH. Prognostic significance of DNA content ard proliferative activicy in large bowel carcinoma. Cancer Res (accepted).

17. Feiz WFJ, Beck HLM, Smeets AWGB, Debruye FMJ, Vooys GP, Herman GJ, Ramaekers FCS. Tissue specific markers in flowcytometry of urological cancers: cytokeratins in bladder carcinoma. Int I Cancer 36: $349-356,1985$.

13. Rognum TO, Thorud E, Elgjo K, Brandtzag P Orjasater H, Nygard K. Large bowel carchomas with difrerent ploidy, related to secretory component $I$ G and CEA in epithelium and plasma far Cancer 45: $921-934,1982$.

19. Sued GO. Growth kinetics of tumours. Clarendon Press, Oxford, 197\%.

20. Gratzer HG. Monoclonal antibody to 5-bromo- and 5-iododeoxyurdine: a new reagen lor detecrion of DNA replication. Science 218: 474-475, 1982.

21. Goz B. The effects of incorporation of 5-halogenated deoxyurines into the DNA of whatryotic aels. Pharmacol Rer 29: 249-272, 1978.

22. Bodell WJ. Rasmussen J. A 32 P Postaboling assoy for determining the incorporation of bromodo. axyuridine into cellular DNA. Anal Bochem 142: 525-528, 1984.

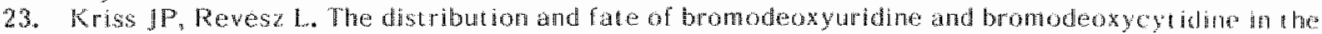
mouse and rat. Cance Res 22: 254-265, 1962.

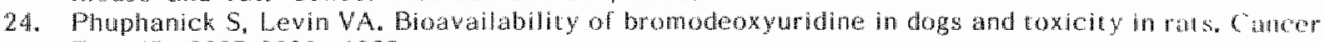
Res 45: 2387-2389, 1985.

25. Begg AC, MCNally N. Schrieve DC, Karcher H. A method to measure the duration of DN A snthesis and the potential doubling time from a single sample. Cytometry 6: 620-624, 1935.

26. Courd $A$. Tubiana Mi, Chavaedra N, Walase EP, Le Fur R. Changes in labeling indian all human tumos after irradiation. Int I Radiation Oncology 6: 1639-1644, 1980 .

27. Fowler JF. Potental for increasing the differental response between tumors and nommal tistues: can proliferation rate be wsed. Int J Rad Oncol Biol Phys $12 * 641 \ldots 645,1986$.

28. Teofori L. Barlogie B, Drewinko B, Swartzendruber D, Mauro F. Reduction of 1-B-D-arabinofura-

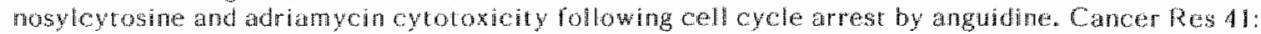
$1263-1270,1981$.

29. Talpaz M, Kartarjan HM, MaCredie K. Trujillo JM, Keating MJ, Guterman JU. Hematoliggia remission and cylogenetic improvement induced by recombinant human interferon alpha An ohronic myelogenous lenkemia. New Engl I Med 314: 1065-1069, 1986.

30. Buset M, Lipk in M. Winawer $S$, Swaroop $S$, Friedman E. Inhibition of human colonic eptibelial cell proliferation in wivo and in vitro by calcium. Cancer Res 46: 5426-5430, 1986. 
This thesis describes a flow cytometric study on ploidy and proliferative activity in colorectal carcinoma. The aim of the study was to evaluate ploidy and proliferative activity, as reflected by the percentage of DNA synthesizing cells, as pretreatment prognostic parameters.

Until recently, flow cytometry was restricted to the use of fresh tumor tissue. In chapter 2 the feasibility of using paraffin-embedded tumor tissue for determination of cellular DNA content was investigated. The DNA derived fluorescence intensity in this material was always decreased and showed a much higher intersample variability compared to that obtained with fresh material. Using chicken red blood cells as a model system, we found that the lower fluorescence intensity is caused by the formalin fixation step. The intersample variability was found to be at least partly caused by variations in the duration of fixation, which for routine pathology samples is not standardized. For standardization, nuclei from paraffin-embedded normal and tumor tissue and processed simultaneously were mixed. With this method DNA indices of 24 colorectal cancers were found to be closely correlated with DI obtained from fresh tumor tissue samples from the same patients. The correlation of the percentages of S-phase nuclei between paraffin-extracted and fresh samples was as high as could be expected, taking sampling differences into account. In chapter 3 the retrospectively measured ploidy and percentage of S-phase cells and the relation of these parameters with clinicopathological parameters was investigated in 279 colorectal carcinomas. There was no correlation between DNA index or percentage S-phase cells and stage, grade, age, plasma CEA level or immunoreactivity for secretory component, serotonin and $\mathrm{Ca}$ 19-9. However, expression of CEA and absence of mucin production were associated with aneuploidy. In addition, tumors in the left hemicolon, ulcerative tumors and tumors which presented with anal blood loss, were more frequently aneuploid. Chapter 4 reports on the comparison of phenotypic and genotypic characteristics between 87 primary large bowel carcinomas and their lymph node metastases. Primary tumors and their metastases were quite comparable in their phenotypic features. In the few discrepant cases, metastases did not invariably show a more restricted pattern than primary tumors, suggesting high differentiational plasticity of colorectal cancer cells. In the majority of cases no differences in DNA index were found. However, in a limited number of cases, genotypic discrepancies were 
observed, indicative of selection in metastases.

Chapter 5 describes a study of the prognostic signficance of ploidy levels and proliferative activity in 279 cases of large bowel carcinomas. A borderline significant association between ploidy and survival was found, with a 75 th quantile survival of 49.8 months for patients with diploid tumors and 35.9 months for patients with aneuploid tumors. After stratification for staging, only Dukes' C cases showed a statistically significant association between tumor ploidy and survival. Survival analysis for proliferative activity and disease-related death showed a similar outcome with the strongest association in Dukes' C stage of disease (75th quantile survival of 38.9 months for low proliferative and 18.0 months for high proliferative tumors).

In chapter 6 the limitations of DNA flow cytometry are discussed and the rationale for dynamic cytokinetic studies using BrdU incorporation is presented. It might be obvious that a static measurement such as the determination of S-phase cells can not: describe a dynamic process such as cellular growth accurately. Chapter 7 describes a new flow cytometric staining protocol for the immunocytochemical detection of BrdU labeled nuclei. Pepsin treatment of ethanol fixed cells or tissue followed by DNA denaturation at low $\mathrm{pH}$ resulted in increased sensitivity, comparable to the thermal denaturation protocol. The technique is applicable to cell suspensions, including cultured cells and bone marrow cells. Furthermore, pepsin digestion of ethanol fixed tissue fragments resulted in a high recovery of nuclei in which incorporated BrdU could be detected. This possibility, together with the high sensitivity, makes this method especially suitable for cell kinetic studies of human solid tumors.

In chapter 8 pepsin digestion of tissue sections was tested for its ability to increase anti-BrdU immunoreactivity. It was found that pepsin digestion prior to acid denaturation of cellular DNA, could increase anti-BrdU immunoreactivity in a fixative dependent way. With crosslinking agents such as formalin and glutaraldehyde high pepsin concentrations could be used before seriously affecting morphology.

Chapter 9 describes a rapid and convenient immunocy tochemical method for the simultaneous detection of antigen expression and S-phase cells by means of anti-BrdU antibodies. For the dual peroxidase staining technique the $\mathrm{DAB}$ color modification by cobalt ions was used. It was shown that antigen localization was not affected by the BrdU staining protocol. The technique can 
be performed on frozen or paraffin-embedded tissue and cytocentrifuge preparations and allows cytokinetic studies of phenotypically defined cells in heterogeneous populations.

In chapter 10 a detailed cytokinetic study was made on 13 collorectal cancer cell lines using BrdU incorporation with subsequent immunocytochemical detection. It was found that there were no systematic differences in labeling indices, potential doubling times and growth fractions between diploid and aneuploid cell lines either grown in vitro or as xenografts in nude mice. When grouped according to grade, moderately differentiated xenografts showed longer volume doubling times than poorly differentiated xenografts, whereas again no differences were measured in the potential doubling time. It is concluded that cell loss is an important determinant of the tumor growth rate. It is postulated that terminal differentiation, leading to a programmed cell death, is most likely responsible for the observed differences.

Chapter 11 contains a general discussion and highlights the biological and clinical relevance of dynamic cell kinetic measurements. 
In het eerste deel van dit proefschrift wordt een flow cytometrische studie beschreven van de ploidie graad en proliferatieve aktiviteit van tumoren van de dikke darm. Het doel van de studie was om na te gaan of de ploidie graad en de proliferatieve aktiviteit, in dit geval het percentage DNA synthetizerende cellen, de prognose van de patient kunnen voorspellen. Tot voor kort, kon voor flowcytometrische bepalingen alleen vers tumor materiaal gebruikt worden. In hoofdstuk 2 is onderzocht of paraffine ingebed materiaal geschikt is voor de bepaling van het DNA gehalte van een cel. De intensiteit van de DNA fluorescentie in dit materiaal bleek altijd geringer en vertoonde een grote variatie tussen de verschillende monsters in vergelijking met metingen uitgevoerd op vers materiaal. Met rode bloed cellen van de kip als model systeem werd aangetoond dat de verlaagde fluorescentie intensiteit te wijten was aan de formaline fixatie stap. De onderlinge variatie kon worden toegeschreven aan de variaties in de duur van fixatie, die in de routine pathologie niet gestandardizeerd is. Voor de standardizatie van DNA histogrammen werden derhalve kernen van normaal en tumor weefsel gebruikt, dat gelijktijdig was. Op deze wijze werd de ploidie graad (DNA index) van 24 dikke darm tumoren bepaald. De DNA indices van paraffine ingebed materiaal correleerden in sterke mate met DNA indices van dezelfde tumoren, wanneer deze vers opgewerkt werden. De percentages S-fase cellen, gemeten op beide manieren, vertoonden een geringere correlatie. Dit kan verwacht worden wanneer men bedenkt dat deze bepaling sterk afhankelijk is van waar het monster genomen is.

In hoofdstuk 3 werden de ploidie graad en het percentage cellen in de S-fase van de celcyclus retrospectief gemeten in 279 dikke darm tumoren en vergeleken met klinische en pathologisch gegevens. Er werden geen correlaties gevonden tussen de ploidie graad of het percentage S-fase cellen en de uitbreiding van de tumor, differentiatie graad, leeftijd, plasma CEA spiegels of immunoreactiviteit tegen SC, serotonine en Ca 19-9. Echter, de expressie van CEA en de afwezigheid van slijm produktie werden vaker gevonden by aneuploide tumoren. Ook de linkszijdige en ulceratieve tumoren, alsmede de tumoren, die zich presenteerden met anaal bloed verlies, waren vaker aneuploid. Hoofdstuk 4 beschrijft de vergelijking van de fenotypische en genotypische kenmerken tussen 87 primaire dikke darm tumoren en uitzaaiingen daarvan in de lymfeklieren. Primaire tumoren en 
uitzaaingen in de $\| y m$ feklieren waren vergelijkbaar wat betreft hun fenotypische kenmerken. In enkele gevallen week de ploidie graad van de primaire tumor af van de ploidie graad in de uitzaalingen. Dit wijst er op dat uitzaaiing een selektief proces kan zijn.

Hoofdstuk 5 beschrijft een studie, waarin nagegaan werd of op basis van de ploidie graad en het percentage cellen in de $\mathrm{S}$ fase van de celcyclus, de prognose van de patient voorspeld kon worden. Aneuploide tumoren bleken met een kortere ziektevrije overleving geassocieerd. Dit gold vooral voor tumoren, die reeds uitgezaaid waren naar de naburige lym feklieren (Dukes ' $\mathrm{C}$ stadium). Voor het percentage S-fase cellen werd hetzelfde gevonden, waarbij een hoog percentage S-fase cellen bleek te voorspellen voor een relatief korte overlevingsduur.

In hoofdstuk 6 worden de de beperkingen van DNA metingen met behulp van flow cytometrie beschreven. Tevens wordt aangegeven waarom het meten van dynamische kenmerken van tumorgroei met behulp van de inbouw van bromodeoxyuridine (BrdU) in het DNA van delende cellen, gewenst is. Dergelijke studies vormen het tweede deel in dit proefschrift.

Hoofdstuk 7 beschrijft de ontwikkeling van een nieuwe flow cytometrische techniek voor het aantonen van BrdU, dat ingebouwd is in kernen van delende cellen. Hiervoor werd gebruik gemaakt van monoclonale antilichamen, die voor dit doel gemaakt werden. De techniek maakt gebruik van een pepsine digestie van in ethanol gefixeerde cellen of stukjes weefsel, gevolgd door een denaturatie van het DNA in zuur milieu, teneinde het BrdU beschikbaar te maken voor het antilichaam. Deze methode resulteerde in een verhoogde gevoeligheid ten opzichte van eerder beschreven methodes en kon worden toegepast op beenmerg cellen en cel lijnen. De opbrengst aan losse kernen, verkregen na pepsine digestie, was hoog. Dit alles maakt deze techniek zeer geschikt voor cel kinetiek studies van soliede tumoren.

In hoofdstuk 8 werd deze pepsine digestie uitgetest op weefselcoupes. Door pepsine digestie, voorafgaande aan de DNA denaturatie in zuur milieu, bleek de anti-BrdU immunoreactiviteit toe te nemen. Deze toename van immunoreactiviteit was afhankelijk van het gebruikte fixatief. Wanneer cross-linkende fixatieven gebruikt werden, zoals formaline of glutaraldehyde, konden hogere pepsine concentraties gebruikt worden, zonder dat de morfologie werd aangetast. 
Hoofdstuk 9 beschrijft een snelle en eenvoudige immunocy tochemische methode voor het simultaan aantonen van antigeen expressie en $\mathrm{S}$-fase cellen met behulp van anti-BrdU antilichamen. Voor deze dubbelkleuring werd de DAB kleur modificatie met behulp van cobalt ionen gebruikt. Er werd aangetoond dat de antigeen lokalizatie niet beinvloed werd door de BrdU kleuring. Deze methode kan worden toegepast op vries- of paraffine coupes en op cytospin preparaten en maakt cel kinetiek studies van heterogene cel populaties mogelijk op basis van het antigeen expressie patroon.

In hoofdstuk 10 werden de cel kinetische parameters van 13 dikke darm tumor cellijnem bepaald met behulp van de BrdU incorporatie techniek. Tussen diploide en aneuploide cellijnen bleken geen systematische verschillen in labeling indices, potentiele verdubbellings tijclen en groei frakties aantoonbaar. Dit gold voor zowel de in vitro situatie als voor xenograften van cellijnen in naakte muizen. Wanneer de cellijnen ingedeeld werden op basis van de differentiatie graad, bleek dat matig gedifferentieerde tumoren een langere volume verdubbellings tijd hadden dan slecht gedifferentieerde tumoren. Echter, deze verschillen konden niet door verschillen, gevonden in de potentiele verdubbellings tijden, worden verklaard. De conclusie is dat in deze situatie het cel verlies een belangrijke parameter is voor de groeisnelheid van tumoren. De hypothese wordt ontwikkeld dat een proces van terminale differentiatie, leidend tot een voorgeprogammeerde celdood, de meest waarschijnlijke verklaring is voor de waargenomen verschillen in groeisnelheid. Hoofdstuk 11 bevat een algemene discussie en benadrukt de biologische en klinische relevantie van dynamische cel kinetische studies. 


\section{Full papers}

Bujhan $\mathrm{CH}_{\text {n }}$ Schute B. Flow cylomery in oncology a revlew with emphasis on DNA flow cytomeiry in humbn solid tumors. Weth f Med 26: 314-320. 1983.

Arends $J W$, Wisgers $T$, Schute $B$, Thins CT, Verstinen K, Higers I, Blijham GH, Bosman FT.

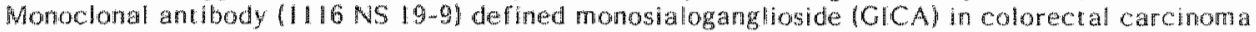
in telation to stage, histopathology and DNA flow cytometry. Int I Cancer 32: 289-293, 1983. Bilham GH. Bladuw 1, Schutre B, Mendes de Leon D. Increased numbers of suppressor-cytotoxic cells in a patient with carbamezepine hypersenstivily. $\Downarrow$ Immunopharmacology $6: 79.86,1984$. Dooveren RFC, Bumman WA, Schute B, Groenewegen $G$ van der Linden $C$ J. Class ll antigens on canine T lymphocyles. Tissue Antigens 25: 255-265, 1985.

de Koning $\mathrm{R}$, Daemen $M$, Schute $B$, Cuertzen HCM, Bliham GH, Bosman FT. Immunofluorescence detection of liver cell membrane reactive ancibodies using PLC/PRF/5-cells. Eur I CHin Unvest $15: 64-68,1985$.

Schutce B, Reynders MMI, Bosman FT, Bliham GH. Flow cytometric determination of DNA ploidy level in nuclei isolated from paraffin-embedded tissue. Cytomerry 6: 26-30, 1985.

Arends JW, Schutte $B$, Wiggers T, Verstijnten ClwHP, Blinam GH, Bosman FT. Comparison of phenotypic and genotypic reacures in primary large bowel carcinomas and lymph node metastases. Cancer Res (accepted).

Schutie B. Reynders Mivil, Wiggers T"Arends JW, Volovics L, Bosman FT, Blijhan GH. The prog nostic significance of DNA concent and proliferative activity in large bowel carcinoma. Cancer Res (accepted).

Schute B, Reynders MMJ, Bosman FT, Blifham GH. The effect of hissue rixation on and-bromodeoxyuridine immunohistochemistuy. J Histochem Cyrochem lim pressl.

Schutce B, Reynders MMJ, van Assche CLMVI. Hupperets PSG], Bosman FT, Bliham GH. Studies with anti-bromodeoxyuridine antbodies. I. An improved methot for the immunocytochemical dethection of Brou labeled nuclei using flow cytometry. Cytometry (in press).

Schutte B, Reynders MMJ, Bosman FT, Blijham GH. Studies with ant i-bromodeoxyuridine antiba dies. II. Simultaneous immunocytochemical detection of antigen expression and DNA synthesis by in vivo labeling of mouse intestinal mucosa. I Histochem Cytochem 35; 371-374, 1987. Nagelkerken LM, Schutre B, Henfling M, wan Breda Vrasman PJC. A monoclonal antibody reactive. whth an RTIn-restricted antigen preferentially expressed by dendritic cells. Transpl Proc (in pressl.

\section{Abstracts}

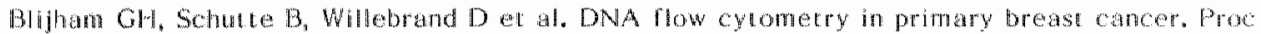
EORTC 3nd Brews Cancer Working Confenence. Amslerdam, WII $23,1983$.

Arends JW, Whgers T, Sohute B, Verstijnen C, Blifhm GH, Higers J, Bosman FT. The walue of Ca 19-9 "NM as astemarker in colorectal cancer. Procedings 2nd European Conference on Clinical Oncology and Cancer Narsing, abstr. 18-24, Amsterdan, 1983.

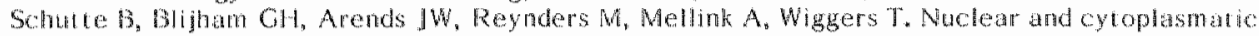
How cytometry of colon cancer. I Exp Clin Cancer Res 2: 15-16, 1983.

Blijham CH, Schuthe B, Reynders M, Wiggers T. Ploidy level and proflferative actiwity are impottan prognosticators in locoregionally adwanced colorecla cancer. Abstract Conference on Thera pentic Strategies in Primary and Metastatic Liver Cuncer, Heidelberg, 17-19 september, 1984. Schute $B$, Reyders $M$, Bosman F. BHijam G. Flow cytometric determination of ploidy lewel and protiferative activity in nucles, isollated from paraffinembedod cissue. Abstract 6th international Symposium on Prevention and Detection of Cancer, Wenen, 26-29 november 1984.

Schute B, Bligham G, Reynders M, Wiggers. T, Volovics L, Bosman FT. Flow cytometric (FVM) detemination of ploidy level and life cycle analysis on 279 parafin-ambedded colorectal carctnoma specimens. Procedings European Sociely of Medical Oncology. Abstract 229, Nice, 7-9 december 1984.

ten Velde GPM, Schute B, Reynders Wibl. Volovics L, Vermenten A, Bliham GH. Prognostic lunction of DNA flow cytometry in non small cell lung carcinoma (NSCLC). Boerhaave Cursus Patmology and Biology of Lung Cancer. Noondwikerhout, 2-4 nei 1985.

Blijham $G$, Schutte B, Reynders M, Wiggers T; Volovics L. Bosman FT. Flow cytometric (FCMil atermination of ploidy level and life arcle andysis an 279 parafin embedded colorectal carcinom specinens. American Socieny of Clinical Oncology, Ebstr. C-804, Houston, 1935.

Schutce $B$. Reynders MBA, Bhinam GH. Measurement of DNA in cells from parafrir-embedded 
tissue. Conference Flow Cytometry: Recent Advances and Future Prospects, Londen, 18-19 april 1985.

Hupperets PSGJ, Schutte B, van Assche C, Reynders M, Blijham GH. Proliferative characteristics of human bone marrow cells following in vivo administration of bromodeoxyuridine (Brdund): a feasibility study. Cancer Chemotherapy and Pharmacology 18; suppl 11; 148, 1986.

Hupperets PSGJ, Schutte B, van Assche C, Reynders MMJ, Bligham GH. Proliferative characteristics of human bone marrow cells following in viwo administration of bromodeoxyuridine (Birdurd): a feasibility study. Proceedings American Society of Hematology, San Francisco, 6-9 december 1986.

Wiggers T, Schutte B, Reynders M, Arends JW, Volovics L, Blijham $G_{n}$ The prognostic value of tumor cell DNA content in colorectal cancer, Proceedings ESSO, Lissabon, 1986.

Schutte B, Reynders MMJ, Basman FT snd Blijhan GH. The simultaneous detection of antigen expression and cell proliferation using anti-bromodeoxyuridine antibodies. European Journal of Cell Biology, suppl.11, vol. 39 , p.34, 1986.

- Schutte B, Reynders MMJ, van Assche C, Hupperets PSGJ, Bosman FT, Blijham GH. An improved method for bivariate BrdUrd/DNA analysis wsing flow cytometry. International Symposium on Clinical Cytometry and Histometry, Neurenberg, p. 155, 20-26 april, 1986.

Schutte B. Simultane detectie van antigeen expressie en DNA synthese met behulp van immunocytochemie. Nederlands Tijdschrift voor Geneeskunde 131: 84, 1986.

Blijham GH, Schutte B, Reynders M, Schouten L. The importance of DNA flow cytomenry for adjuvant studies, in particular in node-negative patients. Fifth International Conference on the Adjuvant Therapy of Cancer, Arizona, 11-14 maart, 1987.

Blijham $\mathrm{GH}$, Schutte $B$, Verstijnen $C_{\text {, }}$ Arends $\mathbb{W}$, Reynders $M$, Bosman F. In vivo and in vitro cytokinetic studies on 13 human colorectal cancer (HCC) cell lines. American Society of Clinical Oncology, Atlanta, 17-19 mei 1987. 


$\begin{array}{ll}\text { BrdU } & \text { 5-Bromodeoxyuridine } \\ \text { CV } & \text { Coefficient of variation } \\ \text { DI } & \text { DNA index } \\ \text { DNA } & \text { Deoxyribonucleic acid } \\ \text { FACS } & \text { Fluorescence activated cell sorter } \\ \text { G }_{0} \text {-phase } & \text { Cell cycle phase occupied with quiescent cells with } \\ & \text { G1-phase DNA content } \\ G_{1} \text {-phase } & \text { Cell cycle phase following mitosis and preceeding } \\ & \text { DNA synthesis phase } \\ \text { G }_{2} \text {-phase } & \text { Cell cycle phase following DNA synthesis phase and } \\ \text { M-phase } & \text { Mitosis } \\ \text { S-phase } & \text { DNA synthesis phase } \\ \text { GF } & \text { Growth fraction } \\ \text { LI } & \text { Labeling index } \\ \text { MoAb } & \text { Monoclonal antibody } \\ \text { RM } & \text { Rellative movement } \\ \text { SD } & \text { Standard deviation } \\ \text { Ts } & \text { S-phase transit time } \\ \text { Tpot } & \text { Potential doubling time } \\ \text { Td } & \text { Volume doubling time }\end{array}$


It is evident that the accomplishment of this study would have been impossible without the active support of many others. Therefore, first of all, I would like to thank Professor Blijham, who made this work possible by introducing flow cytometry to the university of Limburg. Geert, your sympathic, stimulating and always critical approach contributed greatly to this work. I also wish to express my special gratitude to professor Bosman. Fré, without your many suggestions this study would not have its present form. I would like to thank you for all the facilities offered by your department. Geert and Fré, I hope we shall continue our cooperation in the same friendly atmosphere in the future.

Professor Barlogie, I would like to thank you for critically reviewing the manuscript and for introducing me to the field of flow cytometry. My stays in Houston were very fruitfull and pleasant.

I am indebted to professor Böcking and professor Geraerdts for reading the manuscript with great care.

Michèle Reynders, I greatly admire your patience and the devotion to your work. You rapidly got familiar with flow cytometric techniques and your help was invaluable for the completion of this thesis.

The first part of this thesis would have been impossible without the active support of Dr. Theo Wiggers, who took care of the collection and computerization of patient data, and Dr. Jan Willem Arends for the realization of the immunohistochemical studies.

I would like to thank Lex Volovics for the statistical assistance. Drs Pière Hupperets and Chris van Assche participated in the BrdU studies.

My special thanks goes to the Anna and Maurits de Kock Foundation. Their financial support made the purchase of a microcomputer for flow cytometric data storage and analysis, possible. I also wish to express my gratitude to the department of Electronics (head B. van der Steld) for developing the necessary interfacing and software.

Mieke Haemers, you took care of the typing of the manuscript and 1 am grateful for your patience in making all the necessary corrections.

Of all my colleagues of the departments of Internal Medicine and Pathology, who deserve attention, I would especially like to mention Kees Verstijnen especially. Kees, your experience in 
animal handling was of great value to my research.

Finally I would like to thank Karin Daniëls for the the lay-out of this thesis and Karel Jaspars for the many hours he spent preparing the document in the designed lay-out. 
B. Schutte werd op 17 augustus 1955 geboren te Diepenveen. In 1973, na het behalen van het eindexamen Gymnasium B aan de Alexander Hegius Scholengemeenschap te Deventer, begon hij zijn studie scheikunde aan de Rijksuniversiteit Groningen. In 1977 behaalde hij zijn kandidaatsexamen S1, waarna hij een aanvang maakte met zijn hoofvak biochemie (onder leiding van Dr. H.G. Seyen) en bijvak klinische chemie (onder leiding van Prof. Dr. H. Groen). In 1981 behaalde hij zijn doctoraal examen en sindsdien is hij werkzaam bij de afdeling Interne Geneeskunde van de Rijksuniversiteit Limburg te Maastricht. 